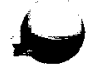

\title{
Geothermal Energy in Wyoming: \\ Site Data Base and Development Status
}

Richard W. James
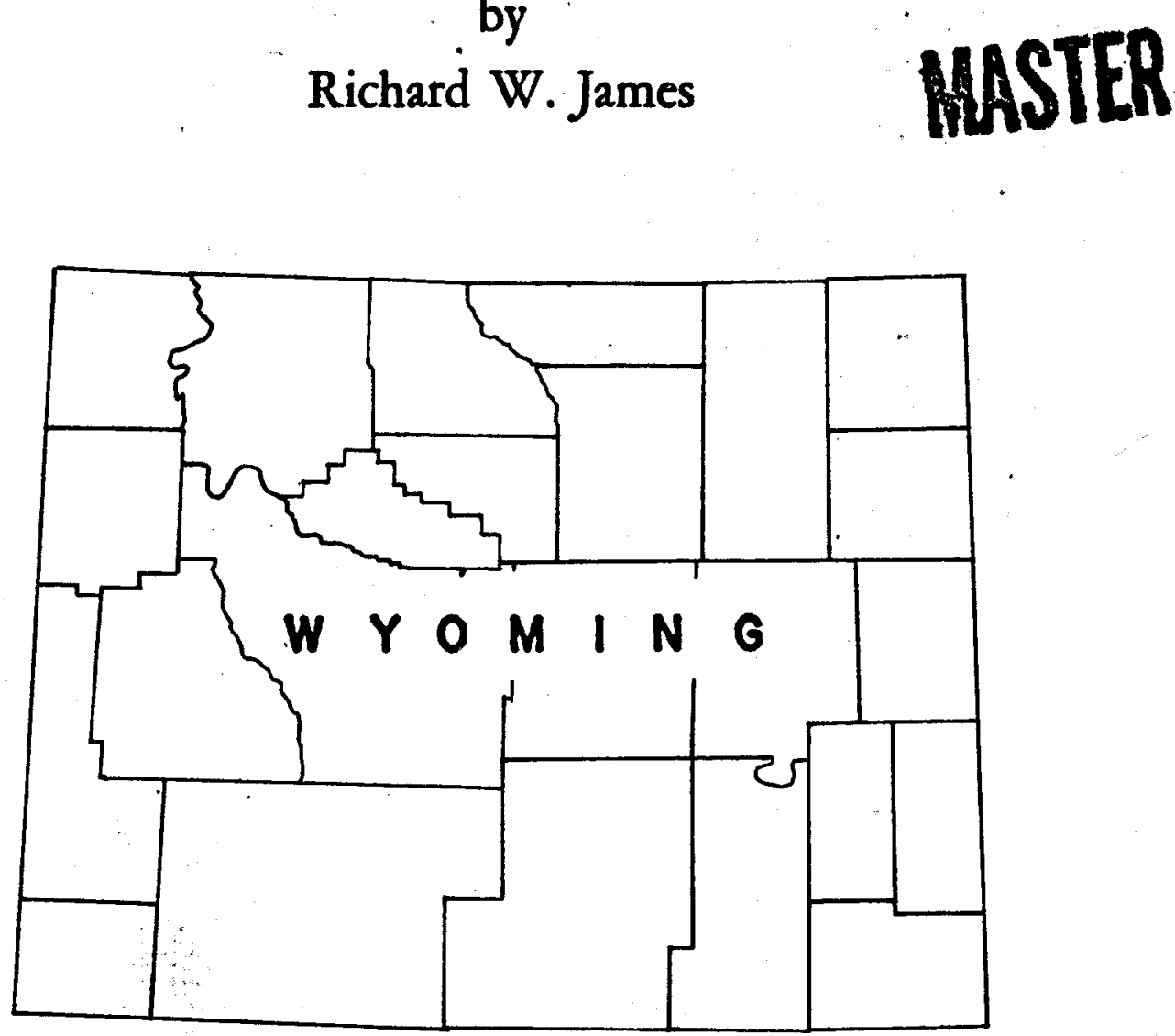

Geo-Heat Utilization Center

Oregon Institute of Technology

Klamath Falls, Oregon 


\section{DISCLAIMER}

This report was prepared as an account of work sponsored by an agency of the United States Government. Neither the United States Government nor any agency Thereof, nor any of their employees, makes any warranty, express or implied, or assumes any legal liability or responsibility for the accuracy, completeness, or usefulness of any information, apparatus, product, or process disclosed, or represents that its use would not infringe privately owned rights. Reference herein to any specific commercial product, process, or service by trade name, trademark, manufacturer, or otherwise does not necessarily constitute or imply its endorsement, recommendation, or favoring by the United States Government or any agency thereof. The views and opinions of authors expressed herein do not necessarily state or reflect those of the United States Government or any agency thereof. 


\section{DISCLAIMER}

Portions of this document may be illegible in electronic image products. Images are produced from the best available original document. 


\section{DISCLAIMER}

This report was prepared as an account of work sponsored by the United States Government. Neither the United States nor the United States Department of Energy, nor any of their employees, nor any of their contractors, subcontractors, or their employees, makes any warranty, expressed or implied, or assumes any legal liability or responsibility for the accuracy, completeness or usefulness of any information, apparatus, product or process disclosed, or represents that its use would not infringe privately-owned rights. 
GEOTHERMAL ENERGY IN WYOMING:

SITE DATA BASE AND DEVELOPMENT STATUS

Prepared for

U.S. Department of Energy (!ISDOE)

San Francisco Operations Office Oakland, California

Contract No. DE-ACO3-79SF1049

by

Richard W. James

Geo-Heat Utilization Center

Apri1, 1979

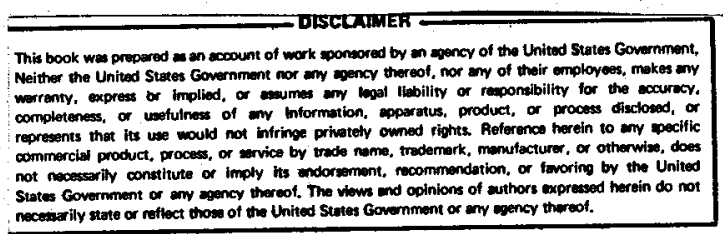

DISTRIBUTION OF THIS DOCUMENT IS UNLIMITED 


\section{Foreword}

Among the most critical of problems facing our nation is energy resources. Though there may be minor disagreement about the specifics, magnitude and solutions to these problems there can be no question about their urgency and of the necessity for immediate action. In an effort to in part resolve these questions by accelerating utilization of one of our renewable resources, the U. S. Department of Energy has developed a program of National and Regional Planning and Operations Research of geothermal energy resources.

The OIT Geo-Heat Utilization Center, under contract to USDOE, has evaluated the geothermal energy resource development potential of the six northwest states of Alaska, Idaho, Montana, Oregon, Washington, and Wyoming. our goal has been to summarize for this region on a site-specific basis the various factors affecting development including resource data base, geological description, reservoir characteristics, environmental character, lease and development status, institutional factors, economics, population and market, and finally potential for development. This report summarizes the known data base for the state of Wyoming, and is in this sense an appendix to the regional report being prepared at the Geo-Heat Utilization Center.

As so little geothermal resource data is available this then represents a progress report in a young but rapidly developing field of knowledge. The continuation of this project now underway is attempting to complete this core of site information and identify data on new significant sites, provide accurate information and recommendations to policy and decision-makers, and ultimately to assist in evolving more effective regional and national geothermal energy programs.

R. P. Koeppen

June, 1979 


\begin{abstract}
"The challenge for a constructive affinity between people, money and government and between englneers, sclentists and techniclans will become Inescapable if the world is to realize a hope that terrestrial heat, manifest in geothermal energy, will take a responsible place as one of the chlef alternatives for fossll and atomic fuels." (Wehlage, 1976)

"In recognizing the finiteness of our natural resources, but not our human resources, we will make the era of alternative energy a reality. The renewable, clean, sober characteristics of geothermal energy is one of the shining examples that will make energy again a servant and not a master." (Tratrier, 1977-1978)
\end{abstract}

Geothermal investigation deals with the reality of resources avallable and the application of the approprlate technology to those resources, to assist in the betterment of man's collective condition. Nearly all recognized geothermal resources in Wyoming are of low to moderate temperatures. The characteristics of these resources tend to IImit their potential development to direct use.

This presentation of information is unquestionably a mere beginning of the evaluation and possible commerclalization of Wyoming's geothermal potential. The intention is to delineate the resources of the state and to identify particular sites which may show promise for development. In Wyoming, an oll producing state, a large amount of fossil fuel use could be replaced by alternate energy sources. Wind, solar, blomass, geothermal and others may contribute to a signiflcant increase in the exportation of fossil fuel from Wyoming. The development and commerclallization of geothermal resources could reduce the in-state use of fossil fuels, providing more for the nation, thus lowering the nation's dependency on foreign oll. This document surveys a group of potentials, based on fact, given as real options for Wyoming.

The information presented herein is for the use of broad range of readers. The officlals of the state of Wyoming may find the information of great assistance, particularly in encouraging new Industry to the state. Counties may find the document useful in bolstering parts of their economies by recognizing new potentlals for thelr current industrles. Homeowners Ilving in areas where geothermal resources are available may find that this information may assist in the development of the resource and provide for great savings in the long run. The taxpayer whose dollars are used for heating municipal bulldings, schools, and other facllitles may see that long term benefits of geothermal development for his community as well as tax savings for himself are possible based on the document's information and references. Industry. too may find new methods for utllizing this important resource in reading the text's suggested applications. The intent is to make the report readable to those who need its information and for it to provide the technical information or references to that information for the initialization of geothermal development in Wyoming.

The research was conducted by gathering preexisting information both 
from published and unpublished sources. Trips were made to many of the sites described as well as to the University of Utah Research Institute in Salt Lake City. Visits to the Wyoming state agencles and the University of Wyoming proved to be very beneficial. Data collection ceased on October 1, 1978.

For the purpose of clarity and simplification in the presentation the state has been divided into five geothermal regions. Those regions have boundaries coincident with those of the State Land Office. There are some distinct administrative advantages to the adoption of the same regions as the State Land Office. The first and foremost is that all state geothermal leasing is done through this office. Other advantages are that the geothermal resources and character of the land seem to suggest the appropriateness of these divisions. A full chapter has been devoted to each of the five regions. Information to support the text is presented at the end of the report in the Appendices.

The assistance of the members of the Geo-Heat Utilization Center at the Oregon Institute of Technology: Paul Lienau, Gene Culver and John Lund and their associates, Charles V. Higbee and William C. Johnson, has been much appreciated. The assistance provided by the following Wyoming state agencies and individuals has been of great benefit: Lynn Dicky and Lorna Wilkes, Energy Conservation Office; John Goddier and Dale Hoffman, Department of Economic Planning and Development, Mineral Division; Donald L. Stinson, Edward R. Decker and E. Gerald Meyer, University of Wyoming; Daniel N. Miller Jr., Wyoming State Geologist. The assistance of Karen Boutain, Big Horn County Planner; Marilyn Norman, Administrative Assistant, Saratoga; The Saratoga Recreation Board; Joe Galovitch, Continental Oil Company; and others has been significant in the preparation of information of specific sites. Andrew Tarshis, Bureau of Land Management; William J. Head, Ed Cox, James Wilson and Samuel West, U.S. Geological Survey in Cheyenne have provided important Federal input. The Principle Investigator, Dr. Don Karr, and the Regional Coordinator, Robert Koeppen, have been of great assistance throughout the project. The patience and support of the Geo-Heat Center secretarles April Leifeste and Colleen Fry has been much appreclated. The contribution of Jonnie Rice in map making and drafting has added clarity and is gratefully acknowledged.

The major thanks in the last analysis must go to my fellow Field Team Members for their help, encouragement and support throughout the project: Don Markle, Alaska; Dave McClain, Idaho; Keith Brown, Montana; Debra Justus, Oregon; and Dr. Gordon Bloomquist, Washington. 
TABLE OF CONTENTS

Page

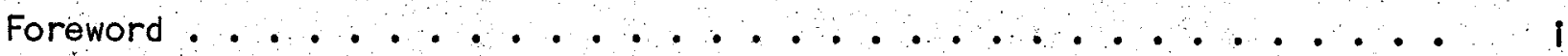

Preface. . . .........................

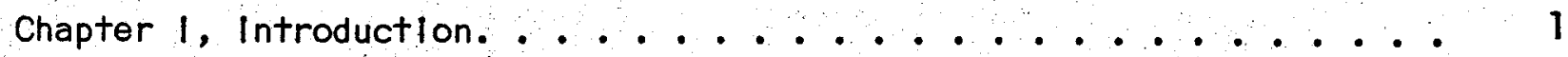

Chapter II, The Wind and Bighorn River Basins. . . . . . . . . 5

Subchapter $\mid 1-1$, LIttle Sheep Mountain Spring ......... 7

Subchapter $\mid 1-2$, Countryman Well...................... 15

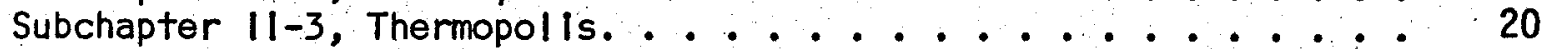

Subchapter II-4, Thermal Springs. . . . . . . . . . . 22

Chapter III, The Powder and Belle Fourch

River Basins. . . . . . . . . . . . . . . 25

Chapter IV, The North Platte RIver Basin . . . . . . . . . . 27

Subchapter IV-I, Saratoga ................. 30

Subchapter IV-2, Midwest/Salt Creek ............. 39

Subchapter IV-3, Glenrock .................. 46

Subchapter IV-4, Thermal Springs................. 51

Chapter V, The Green and Snake River Basins. . . . . . . . . . 55

Subchapter V-I, Auburn. ................. . . 57

Subchapter V-2, U.S. FIsh and WIIdlife
Service, Hatchery. . . . . . . . . . . . . . 67

Subchapter V-3, Thermal Springs ............. 68

Chapter VI, The Yellowstone River Basin. . . . . . . . . . 71

Subchapter VI-1, Yellowstone. . . . . . . . . . 72

Chapter VII, Institutional Considerations. . . . . . . . . . 77

Chapter vill, Summary. . . . . . . . . . . . . . 81

Chapter IX, Recommendations. . . . . . . . . . . . 83

Appendix A, The Madison Formation, . . . . . . . . . . 84

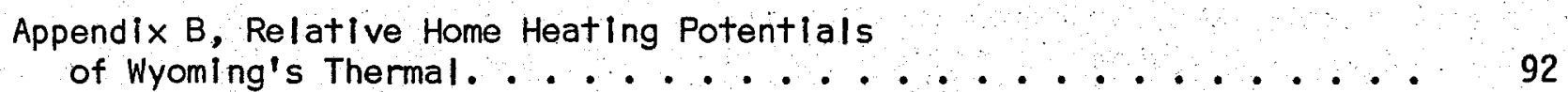

Appendix C, Geothermal . . . . . . . . . . . . . . . . . . 94

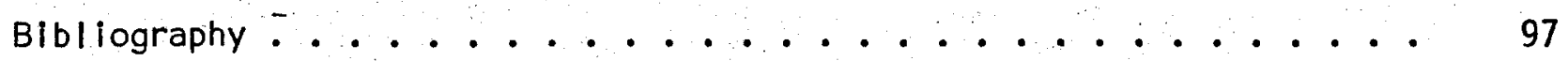

Additional References. . . . . . . . . . . . . . . . 101 


\section{CHAPTER I}

\section{INTRODUCTION}

Geothermal energy is a relatively new and potentially important resource for the future of Wyoming. It is a resource which in some areas of Wyoming is known to have development potential whlle in others the probabllity of successful development is good. Areas such as Saratoga, Midwest and Auburn have the most potentlal for the Immedlate future. The Madison Formation which underlays the Powder River Basin could be very important to many residential, Industrial and community energy needs for much of the state in the future.

The state of Wyoming has a diverse physographic character. The topography varies from the mountains in the west, through which runs the continental Divide, to the Great Plains in the east. It is the second highest state in the nation with an approximate average altitude of 6,700 feet. The highest point is 13,785 foot Gannet Peak In Fremont and Sublett Counties, while the lowest point is 3,100 feet on the Belle Fourche River in Crook County. Wyoming ranks ninth in size among the 50 states, with an area of approximately 97,914 square mlles. Seven Important rivers feeding four major river systems have their headwaters in the state (Wyoming: A Land Use Inventory, 1973).

The state's climate is semi-arid with an average annual precipitation range from five inches in the Red Desert and parts of the Big Horn Basin to 45 inches in the mountains. Wyoming has a large amount of freezing and thawing, with an average annual temperature of $42.3^{\circ} \mathrm{F}$. This has important effects on agriculture, transportation and other activities. Frost free periods vary across the state from a few to 120 days.

The history of the development of Wyoming is linked to the land and transportation. The federal government made land aval lable for homesteading through the Preemption Act of 1841 and later the Homestead Act. This encouraged settlers to move west. The major move to develop. Wyoming was encouragement to railroad developers. Rallroads were often granted rights-of-way through public lands, but a sweeping land grant act in 1862 was to change the rather informal method of rall road development. This act provided grants of land to the Union Pacific and the Central Paclfic Rallroads, whereby the rail companies would recelve alternate sections of land for $20 \mathrm{ml}$ les on each side of the road. The grants to the rall roads had accomplished the purposes of connecting the various states, or rapldly dlsposing of government lands near the rall road beds, and of permitting the quick sale of rall road lands after completion of the railroads. Large individual land and timber holdings resulted from this land grant policy (Wyoming: A Land Use Inventory, 1973).

Wyoming's drainage system is dominated by perennial streams which orlginate in mountainous areas and derive their flow from snowmelt and rainfall runoff as well as groundwater. There are also numerous intermittent streams originating in the lower elevations of the state.

More than $90 \%$ of the water flowing through the state originates within the state's boundarles. Colorado's mountain areas contribute to Wyoming's streamflow via the North Platte, Laramie, and Little Snake Rivers. Montana contributes streamflow in Clarks Fork. The headwaters of the Black Fork, 
Map I-1

Geothermal Regions

of

Wyoming

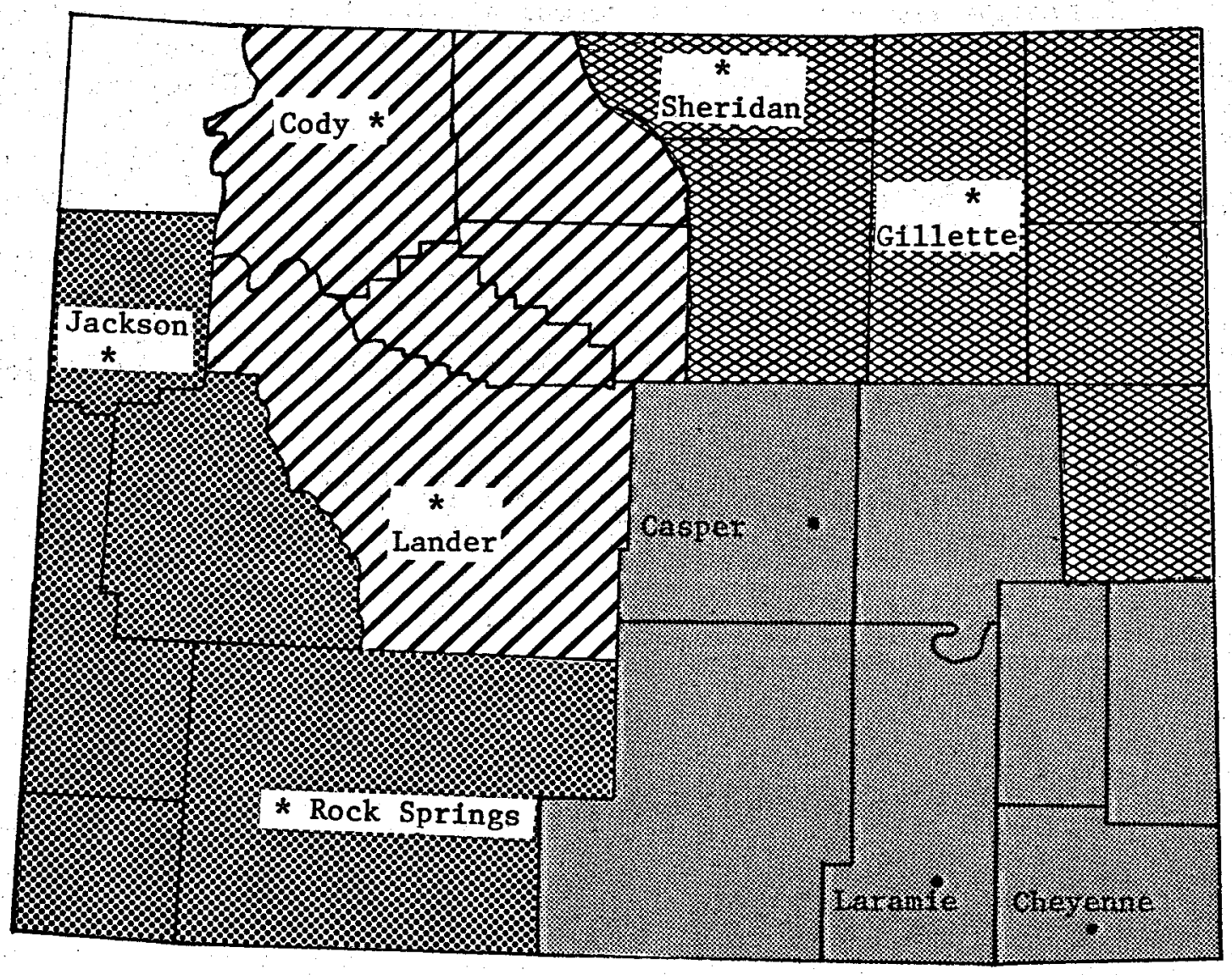

Region 1

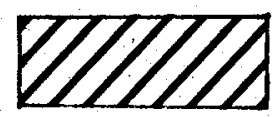

Region 2

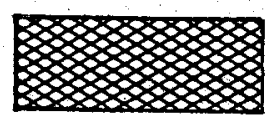

Region 3

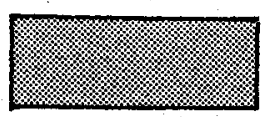

Region 4

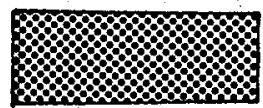

Region 5

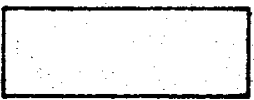


Henreys Fork and the Bear River are in Utah and flow into Wyoming.

About $72 \%$ of the land area of Wyoming drains northward and eastward into the Missouri River system. Tributaries of the Colorado River drain about 17\% of the state toward the south. About 7\% of Wyoming's I and area is dralned by the Bear and Snake Rivers.

The Bear River meanders along the western Wyoming border and ends in Great Salt Lake. The Snake River starts in Wyoming and joins the Columbia River system. These rivers drain about $7 \%$ of Wyoming's land area. The remaining $4 \%$ of Wyoming's land area is internally drained into the Great Divide Basin (Wyoming Framework Water Plan, 1973).

\section{Geothermal Regions}

For clarity, this report divided the state into five geothermal regions. The regions correspond to those used by the State Land office, and are named for the major river basins within them (Map 1-1); Region 1, The Wind and BIghorn River Basins, Reglon 2, The Powder and Belle Fourche River Basins, Region 3, The North Platte River Basin, Reglon 4, The Green and Snake River Basins, and Region 5, The Yellowstone River Basin. The state has no known Geothermal Resource Areas (KGRA) and sixteen areas which have been designated as being "valuable prospectively for Geothermal resources" by the U.S.G.S. Branch of Mineral Classification, Northern Rocky Mountain Region, of Casper, Wyoming and the National Geophyslcal and Solar-Terrestrial Data Center in Boulder, Colorado (Geothermal Energy Resources of the Western U.S., 1977).

Significant exploration has been conducted for oil and natural gas in each of the geothermal regions, except Yellowstone. However, there has been little or no exploration for geothermal resources in the state. The lack of exploration efforts has produced a scarcity of published geotechnical data on which one might base developmental projections. The data which is available for geothermal resources in Wyoming has been incorporated in this report.

Energy Use

Wyoming's energy use is delineated in Table 1-1. Geothermal energy use could offset several of the indicated energy use amounts. Additional electrical power needs which are projected for electrical space heating may be significantly reduced by the use of geothermal energy. Some key communities in the state have good potential for their development of geothermal heating districts. At the time of development of these districts, substantial savings could begin to be reallzed. Natural gas use for space heating could be reduced in these localities as well. In those areas which are presently only served by propane or liquid fuels a great savings could be realized if adequate geothermal resources exist. 
Table 1-1

TOTAL ENERGY USE FOR WYOMING

Total $1975 \mathrm{Btu}$

Electricity**
Natural Gas
Coal
Gasol ine
Diesel
Propane \& Liquid Fuels
Total

$81,436 \times 10^{9}$
$84,848 \times 10^{9}$
$19,221 \times 10^{9}$
$39,325 \times 10^{9}$
$27,263 \times 10^{9}$
$29,347 \times 10^{9}$
$282,182 \times 10^{9}$

$81,436 \times 10^{9}$

$84,848 \times 10^{9}$

$39,325 \times 10^{9}$

$27,263 \times 10^{9}$

$282,182 \times 10^{9}$
Total $1980 \mathrm{Btu}$

$99,520 \times 10^{9}$

$106,725 \times 10^{9}$

$28,649 \times 10^{9}$

$49,193 \times 10^{9}$

$42,356 \times 10^{9}$

$34,857 \times 10^{9}$

$362,180 \times 10^{9}$

(Information gathered in personal communication with D. Hoffman, Mineral Division, Department of Economic Planning and Development, Cheyenne, Wyoming 10/78).

*Projected

** Includes coal used in Electrical generation

The natural energy system of Wyoming is rich and the development of its geothermal potential could make a great contribution to energy efficiency within the state. Also the utilization of geothermal energy could reduce the total amount of non-renewable resources which are consumed. The reduced instate consumption could increase exports of Wyoming oil, gas, coal, and other energy resources, bringing a greater income to the state without an increase in production. 
CHAPTER II

The Wind \& Big Horn River Basins

Region 1

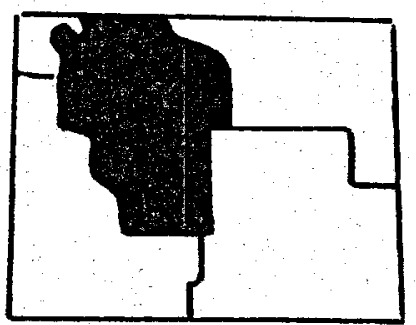

Subchapter

I I - 1

Little Sheep Mountain

Spring

II - 2

Countryman We11

I I -3

Thermopolis

II -4

Site

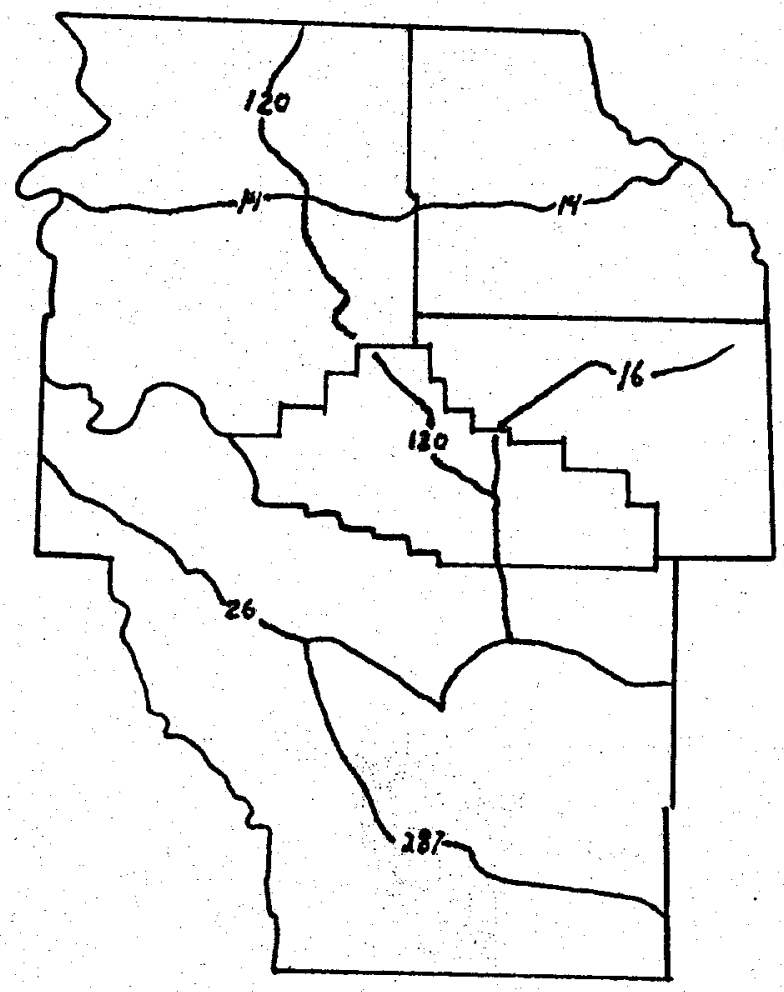

Proposed Use

Treatment

Barley Malting

plant

Scenario

Greenhouse

Discussion

District Heating

Discussion

None 
Region 1, Wind and Bighorn River Basins, is located in the north central part of the state. The region is characterized by two large intermontane basins which are bisected by the Wind and Bighorn Rivers. Major mountain ranges are found on the northeast (Bighorn Mountains) and southwest (Wind River Mountains) borders. Yellowstone National Park borders the region on the northwest. The major industries in the region are agricultural, which form the somewhat suffering economic base. The region contains five counties and the Wind River Indian Reservation. There are seven areas identified as valuable prospectively for geothermal resources in this region.

Region I has five counties whose residents make up $21 \%$ of the population of the state. The five counties are Park, Big. Horn, Washakie, Hot Springs, and Fremont, with Washakie being the only one without surface manifestation of thermal activity. The other four counties will be discussed in a priority order based on the probabllity of development. The possibility of a barley malting plant being developed in the Big Horn Basin will be given the most attention. Estimates of subsurface temperatures made on the known resources in the basin seem to lead to the need for detailed study of potentials at the site of Little Sheep Mountain Spring on the Big Horn River. Another area of interest in this region is the various springs and wells near Thermopolis in Hot Springs County where a varlety of uses of the geothermal potential could be made without tapping the springs located at Hot Springs State Park. Further south in Fremont County, one of the first oll wells drilled in Wyoming is of interest. This privately owned well has a constant artesian flow of water and is currently being used to heat a greenhouse at the site. 


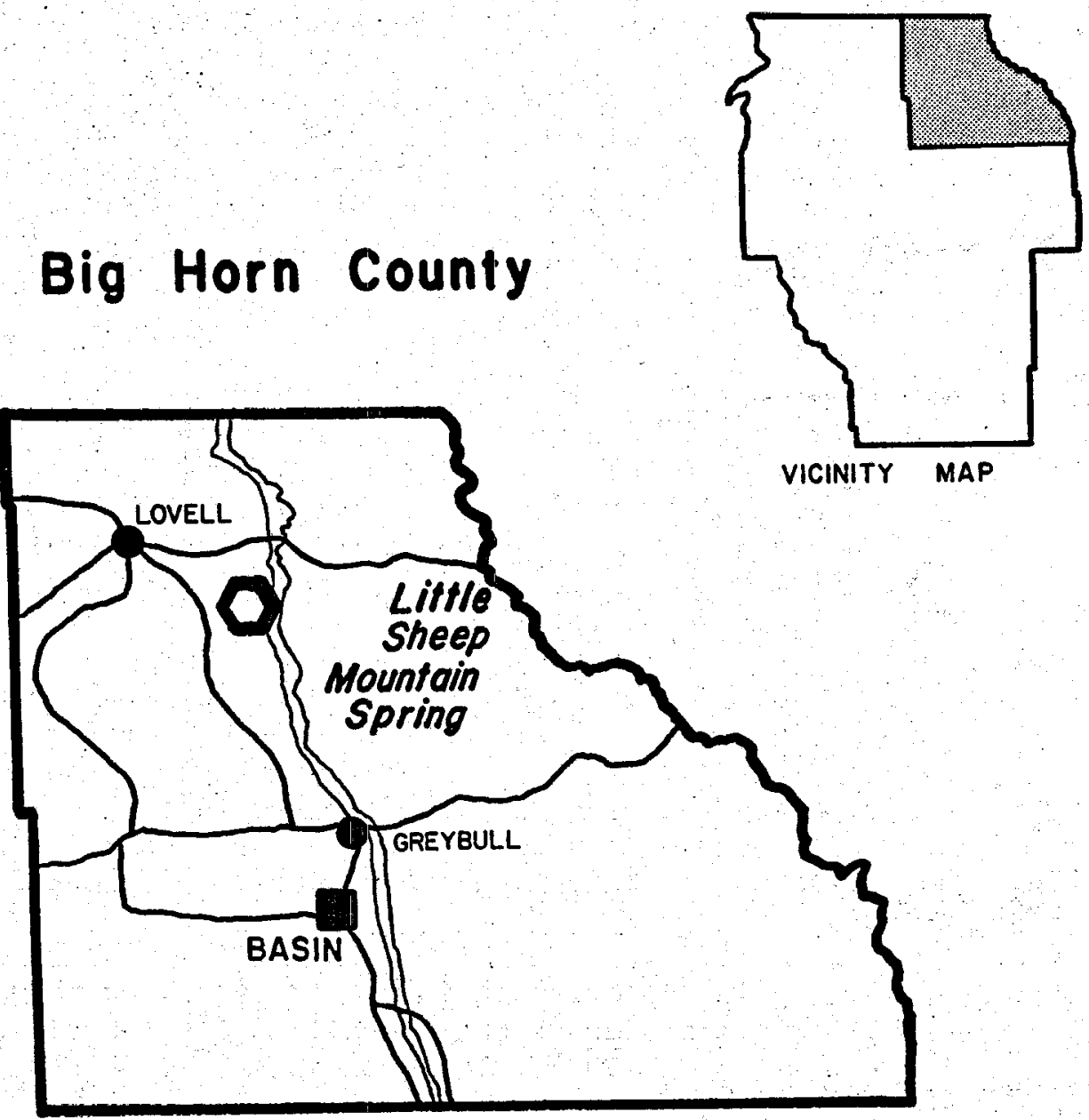

0 Detailed Scenario Narrative

Darrative

County Seats

(1) Cities or Towns 
Subchapter 11-1 Little Sheep Mountain Spring

Big Horn County in the north central part of Wyoming is bordered on the east by the Big Horn Mountains and on the west by the level plain of the Big Horn Basin. The northerly flowing Big Horn River divides the County into eastern and western halves. The western half is primarily dry, hilly and mountainous country. This is the eastern slope of the Big Horn Mountains and the higher elevations are covered with confier forests. The western half of the County is characterized by the broad farm lands of the basin where barley, wheat, and sugar beets are major crops. The majority of the population of the County lives west of the Big Horn River.

Little Sheep Mountain Spring is located on the Big Horn River about 16 miles east of Lovell and 20 miles north of Greybull. The spring is located in a canyon with the only access by the Burlington Northern Railroad tracks which lay on the west bank of the river. Little use has been made of the spring because of the difficulty of access. The history of the spring is limited to a few references in geologic discussions of the area and the knowledge of the local people (Breckenridge, 1978, p. 8).

The spring has a sizable flow $(1800 \mathrm{gpm})$ but a low surface temperature $\left(20^{\circ} \mathrm{C}\right.$.) .... The use of a sillica geothermometer gives a reading of $125^{\circ} \mathrm{C}$. based on the content of the silica in the water at the surface. This calculated temperature is one indicator of many factors that should be analyzed. Nevertheless, it does point to the possibility of a significantly valuable resource at this site. Also higher surface temperature $\left(27^{\circ} \mathrm{C}\right.$.) have been recorded in nearby caves (Breckenridge, 1978, p. 9).

Considering that the geothermometer gave a temperature of $125^{\circ} \mathrm{C}$. or $257^{\circ} \mathrm{F}$. at depth, further reservoir analys is could indicate that similar temperatures and flow may be found by drilling in a geologically adjacent area to Little Sheep Mountain Spring. Resource temperatures encountered greater than $200^{\circ} \mathrm{F}$. could be used by a barley malting plant which would utillize the geothermal resource and the agricultural products of nearby agricultural areas.

Barley malting is a process that is readily suited to direct use of geothermal energy. It is a year-around operation with industrial temperature levels using a maximum of $190^{\circ} \mathrm{F}$. The process itself is uncomplicated and includes only three major steps.

The barley is first cleaned and then steeped in cold water for 12 to 48 hours. The purpose of steeping is to raise the water content of the barley above $40 \%$ without causing germination. The steeping water should be $50^{\circ} \mathrm{F}$. to $60^{\circ} \mathrm{F}$, (Coury, 1978).

Germination, the second process, takes place in large bins under environmentally controlled conditions using temperatures of about $65^{\circ} \mathrm{F}$. for about 5 days. A continuous air flow through the bed is essential. To prevent drying of the barley, and to replace water lost during the respiration process, the inlet air is sprayed with recirculating water to maintain relative humidity at $100 \%$. On an annual basis about 20 to $30 \%$ of the energy requirements for a barley plant are consumed in the germination bins for space heating with the remainder used in the drying kilns. 
The germinated barley is then dried to produce malt with $3 \%$ water. Drying is done on a dally cycle. Five or six hours are taken to cool and unload the prevlous batch and to then charge the kiln with new germinated barley. Drying takes place for 18 to 19 hours by passing hot alr through the bed at temperatures ranging from $130^{\circ} \mathrm{F}$. at the start of the cycle to about $180^{\circ} \mathrm{F}$. at the end (Coury, 1978).

In the geothermal system air is heated by the brine to the desired temperature by use of heat exchangers and then blown through the drying kilns. The application of a compressor and/or heat pumps to various stages of the process may prove to be financlally beneficial.

Coury (1978) states that a resource temperature of $220^{\circ} \mathrm{F}$. and flow of $8000 \mathrm{gpm}$ would require a total investment of $\$ 2.52 / \mathrm{mil}$. Btu. This cost would require capltal Investment of $\$ 1.95 / \mathrm{mil}$. Btu. Including $25 \%$ added charges for pumps, heat exhangers, etc.; and $\$ .57 / \mathrm{mll}$. Btu. for brine treatment. Additionally, he suggests that a total of seven wells be drilled including a spare production well and reinjection wells for a total of $\$ 473,000.00$ annually with a $15 \%$ amortization rate. 
GEOTHERMAL ENERGY EVALUATION

\section{NON-ELECTRIC GEOTHERMAL ENERGY APPLICATIONS \\ SITE: Little Sheep Mountain Spring}

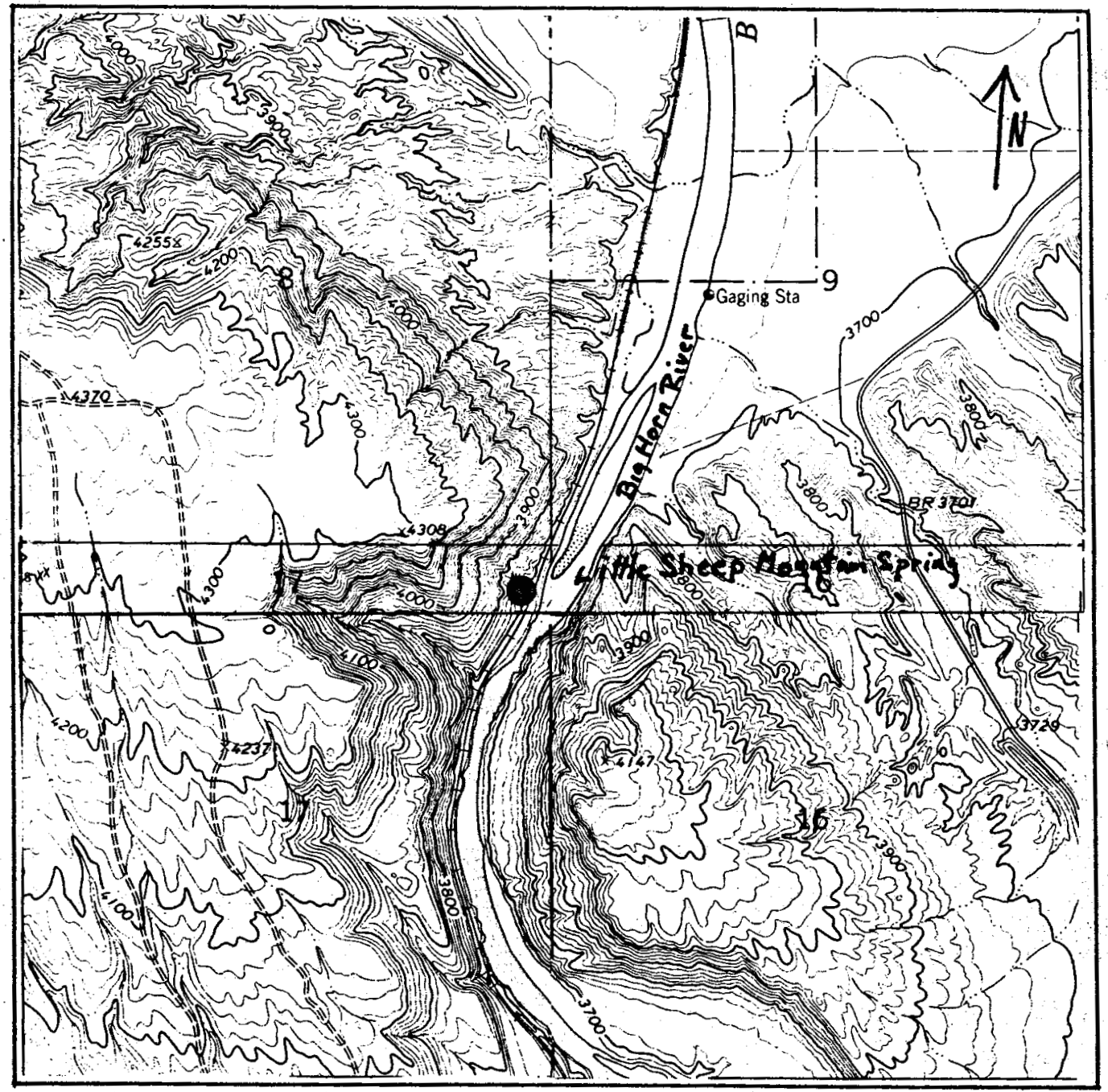

(Base map from USGS Kane and Spence Quadrangles, Wyoming -

Big Horn County, 7.5 Minute Series, Topographic, $1964 \& 1966)$. 
SITE DATA SUMMARY

Physlcal Reservoir Data:

Temperature at Surface: $18-20^{\circ} \mathrm{C}$.

Temperature at Subsurface: $125^{\circ} \mathrm{C} .\left(\mathrm{SlO}_{2}\right)$

Total Dissolved Solids (PPM) : 296

Estimated Non-Electric Energy Potentlal (MBtu/h 30 years): No estimate Geothermal Development Status: None

Local and State AttItude Toward Geothermal Development: There is interest

in the Big Horn Basin in the development of a barley malting plant.

The state is just becoming aware of the potentlal of geothermal.

Land Use and Population: Currently the area is used for grazing only.

Comments and Critical Issues: Access to the resource may be a problem.

\section{SITE LOCATION AND PHYSICAL DESCRIPTION}

Latitude:

Longitude:

$44^{\circ} 45^{\prime} \mathrm{N}$.

Rectillinear:

$108^{\circ} 15^{\prime} \mathrm{W}$.

County:

Sec. 17, T55N, R94W

Adjacent Counties:

Big Horn

Topography:

Present Land Use:

Sheridan, Johnson, Washakle, Park, in Montana; Carbon and Big Horn

The spring lles in a mountainous canyon on the bank of the Blg Horn RIver access should be to the north.

Future Land Use Plans: None beyond a potential of malt plant development.

\section{GEOLOGICAL/GEOPHYSICAL DESCRIPTION}

Geologic Description:

Spring issues from a cave at the base of a cliff on the west side of the Big Horn River. It seems to flow from the cave and into the Big Horn River from the Madison Limestone.

Geologic Hazards:

Significant difficulty in drilling at or near to the spring location caves, cliffs, unstable ground and poor access.

\section{RESERVIOR CHARACTERISTICS}

Reservolr Temperature:

Surface: $\quad 18$ to $20^{\circ} \mathrm{C}$.

Subsurface: $125^{\circ}\left(\mathrm{SlO}_{2}\right)$ Projected temperature, $11 \mathrm{mited}$ confidence

Geochemical: $\mathrm{SlO}_{2}: 82 \mathrm{ppm}$ 
Flow Rates: $\quad 1800 \mathrm{gpm}$

$\mathrm{pH}: \quad 8.0$

Total Dissolved Solids: 296 ppm

Fluid Chemistry:

$\begin{array}{llllll}\mathrm{Ca} & 54 & \mathrm{Ppm} & \mathrm{F} & .5 & \mathrm{ppm} \\ \mathrm{Mg} & 25 & " & \mathrm{~S} & .001 & " \\ \mathrm{Na} & 4.7 & " & \mathrm{SiO}_{2} & 82 & " \\ \mathrm{~K} & 1.4 & " & \mathrm{~B} & .02 & " \\ \mathrm{CO}_{3} & 0 & " & \mathrm{TDS} & 296 & " \\ \mathrm{HCO}_{3} & 210 & " & \text { Hard } & 230 & " \\ \mathrm{SO}_{4} & 81 & " & \text { Tot. } \mathrm{CO}_{3} & 100 & " \\ \mathrm{Cl}^{2} & 4.5 & " & \mathrm{pH} & 8.0 & \\ \mathrm{NO}_{3} & .7 & " & \text { (Breckenridge, 1978 p.10). }\end{array}$

Subsurface Area of Reservoir: Unknown

GEOTHERMAL DEVELOPMENT STATUS

Present Development Status: None

INSTITUTIONAL CONSIDERATIONS

\begin{tabular}{|c|c|}
\hline $\begin{array}{l}\text { Institutional } \\
\text { Requirements }\end{array}$ & $\begin{array}{c}\text { Institutional } \\
\text { Agency } \\
\end{array}$ \\
\hline $\begin{array}{l}\text { Zoning } \\
\text { Water Rights } \\
\text { Geothermal Use } \\
\text { Industrial Permit }\end{array}$ & $\begin{array}{l}\text { County Planning } \\
\text { State Eng. } \\
\text { State Land Office } \\
\text { Rural Level Area } \\
\text { Planning Commissio! }\end{array}$ \\
\hline
\end{tabular}

ENVIRONMENTAL FACTORS

CLIMATE:

Prevailing Winds: W.

Precipitation (Annual): $6.5 \mathrm{in}$.

Days of Sunshine (Annual): 300

Average Annual Temperature: Minimum: $31^{\circ} \mathrm{F}$.

Maximum: $57^{\circ} \mathrm{F}$.

AIR QUALITY:

Stable with tendencies toward winter inversions

BIOLOGICAL:

Dominant Flora:

Upland

Low growing big sagebrush 
Assoclates:

\author{
River Bottom \\ Cottonwood \\ Will lows \\ Glant Rye Grass
}

Rabbit Bush

Hop Sage

$\mathrm{Salt}$ Bush

\title{
Alkaline \\ Greasewood \\ Bud Sage \\ Salt Bush
}

Dominant Fauna:

Mamma/s

Birds

Antelope

13-line ground squirrel

Golden eagle

White tailed prairle dog

Raven

Badger

Red talled hawk

Coyote

White talled jack rabbit

cottontall

ENDANGERED SPECIES :

Flora: None inventoried

Fauna: Black footed ferret

Bald eagle

Peregrine falcon 
Utility or Energy Transmission Corridors and Facilities: A gas line is serving Himes, $10 \mathrm{miles}$ to the south and crosses BLM land.

Transportation Corridors or Facilities: Burlington Northern R.R. track is immediately adjacent Route 789 and 310 are 10 miles to west of site.

Site is 30 miles east of Lovell

Site is 35 miles north of Greybull

\section{POPULATION}

General Description of Population in Big Horn County

Resource based economy

Agriculture

Mining

Timber

Tourism

Oil

Retail

Emp loyment

$33 \%$ local government

$33 \%$ agriculture

13\% manufacturing

$21 \%$ mining

Economics: 79.5\% of Big Horn County land is federally managed by BLM and National Forest Service.

Future Land Use: Similar to present. Uranium mining may soon be in Montana north of Cowley. 


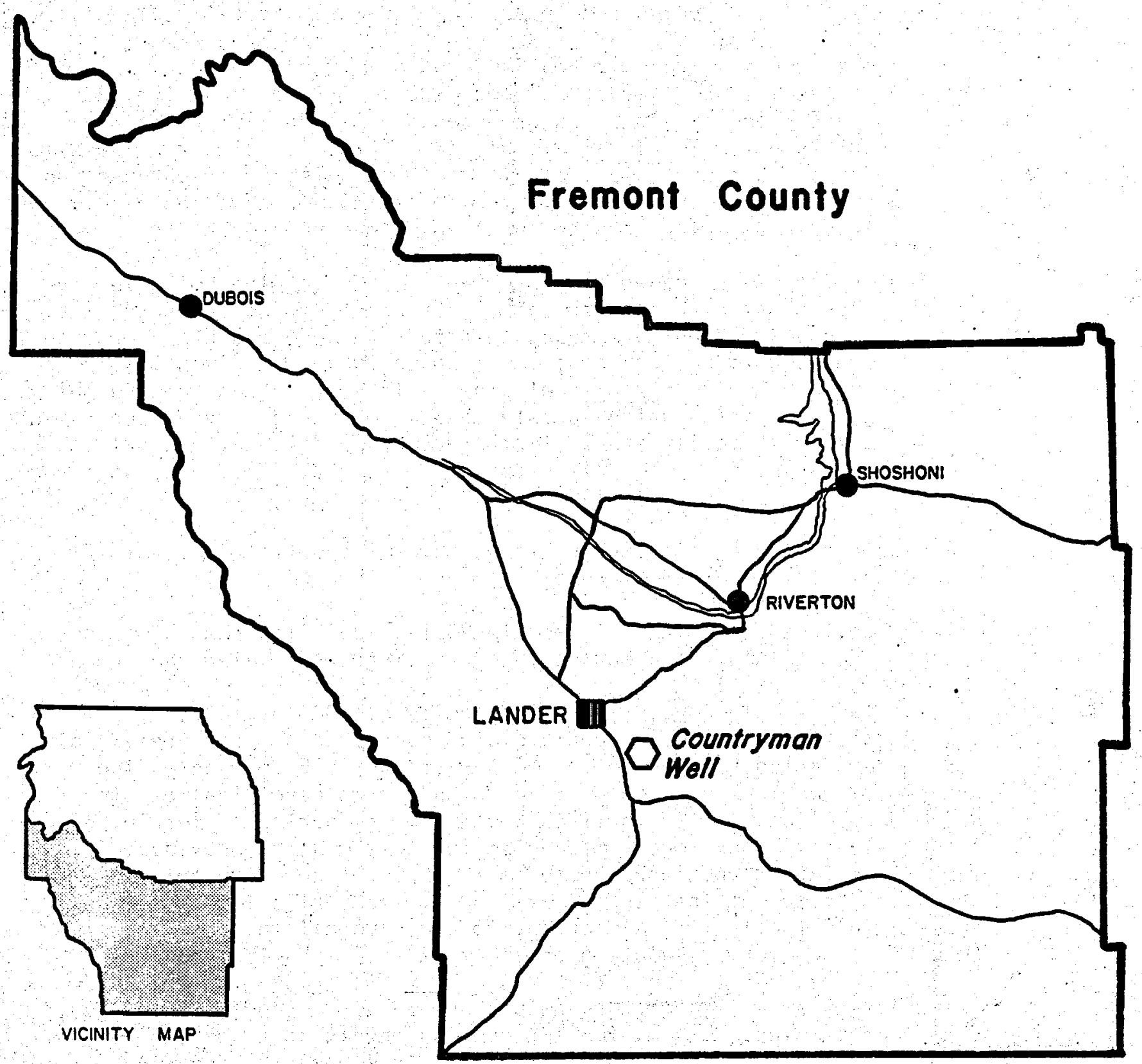

0

Detailed

1 County Seats Scenario Narrative

O Narrative

- Cities or Towns 
Subchapter 11-2 Countryman Well

The Countryman well is located about ten miles southeast of Lander. It is one of the oldest oil wells to be drilled in Wyoming. Since it was drilled in 1884, the well has produced very small amounts of oll mixed with large volumes of water. For a time the well was capped but now flows at a regular rate of $500 \mathrm{gpm}$. The well is presently owned by the Countryman ranch and is about $1 / 2 \mathrm{mile}$ away from the house and 500 feet above it on a hillside.

Water flows from the well at about $500 \mathrm{gpm}$ and at about $100^{\circ} \mathrm{F}$. into a large pool. The pool is a dammed area about 100 feet long and 5 feet deep. Immediately adjacent to the pool is a greenhouse which the owner has been using for several years. The immedlate use of the well's hot water seems to be somewhat complex. Present plans are to heat the existing greenhouse and perhaps to add more greenhouses later. The potential for this resource would not necessarily be restricted to space heating of greenhouses.

Originally the resource was used by means of running the hot water through the greenhouse in an open trough. This proved to be inadequate as the concentrations of $\mathrm{H}_{2} \mathrm{~S}$ which escaped into the air were too high for the plants to tolerate, killing most of them. Thought was then given to piping the water through the bullding in steel pipe as is done in many geothermally heated greenhouses. Here a unique problem was encountered at the countryman well. This well periodically issues forth large quantities of red silt, apparently from cave-ins of the well deep in the ground. This silt would rapidly plug any conventional system.

Considering these particular problems, several possibilities exist for the improvement of the resource's use:

(1) The well water could be pumped 10-20 feet up hill from the greenhouse, (the artesian flow may be enough to force the water that much higher) to a large tank.

(2) The tank should have a minimum capacity of 1000 gallons, be steel or concrete in construction and contain several unique features: (a) Two large baffles affixed to the bottom of the tank over which the water must flow. These would serve to encourage precipitation of suspended solids, (b) the baffles would require perlodic cleaning of the precipitate therefore a mechanism for this must be provided, (c) the exit point of the tank should be lower than the entry point but above the bottom of the tank to avoid draining particulate into the system, (d) finally it is important to conserve all the heat that is possible, therefore insulation of the tank and pipes is essential.

The delivery system to the greenhouse should be thoroughly insulated, asbestos concrete pipe. The system for heating should be a series of steel pipes used as a radiator assisted by fans for air movement. The discharge could be used for other purposes as it will most likely use little of the total heat available. Uses such as space heating of the house and barns would be excellent initial uses of the resources.

The resource is exceptional and its location, on a hill, is also important. Without consideration being made for distance of pipelines, temperature loss, and etc., the resource could heat several homes, a substantial resource. 


\section{SITE DATA SUMMARY}

Physlcal Reservolr Data:

Surface Temperature: $38^{\circ} \mathrm{C}$.

Type of Overlaying Rock: Tensleep formation

Site Land Status:

Total Acres - all private

Geothermal Development Status: Currently used for a greenhouse and pool Local and State Attitude Toward Geothermal Development: State, interested

In other resources; local, virtually unaware of geothermal potential Land Use and Population: Rural ranching

\section{SITE LOCATION AND PHYSICAL DESCRIPTION}

Lat Itude:

Longitude:

Rectilinear:

County:

Adjacent Counties:

Topography:

Present Land Use:

Future Land Use Plans:

HIstorical/Archaeologlcal Significance:

Geologic Description: $42^{\circ} 45^{\prime}$

$108^{\circ} 30^{\prime}$

Sec. 15, T3IN, R98W, of $43^{\circ} \mathrm{N}, 109^{\circ} \mathrm{W}$ Fremont Hot Springs, Natrona, Carbon, Sweetwater, Sublette, Teton, and Park Sage brush covered hills, bordering small valley floor

Grazing In general; greenhouse, Immediate area Multiple greenhouses

Oldest ol Iwell in Wyoming, 1884 Water issues from Madison Limestone, perhaps from Tensleep sandstone

\section{RESERVOIR CHARACTERISTICS}

Reservoir Temperature: Surface, $100^{\circ} \mathrm{F}$.

Flow Rates: $500 \mathrm{gpm}$

GEOTHERMAL DEVELOPMENT STATUS

Present Development Status: Greenhouse and grazing

Projected or Planned Development: Multiple greenhouses with the potential for a development

\section{ENVIRONMENTAL FACTORS}

Biological:

Dominarit Flora:

Upland

Low growing big sagebrush 
Associates:

Rabbit Bush

Hop Sage

Salt Bush

\section{River Bottom}

Cottonwood

Willows

Giant Rye Grass

Alkaline

Greasewood

Bud Sage

Salt Bush

Dominant Fauna :

Mammals

Birds

Antelope

13-1 ine ground squirrel

White tailed prairie dog

Badger

Coyote

White tailed jack rabbit

Cottontail

Endangered Species:

Flora: None inventoried

Fauna: Blackfooted ferret

Bald eagle

Peregrine falcon

\section{Golden eagle} Raven

Red tail led hawk Prairie horned hawk 
TRANSPORTATION AND UTILITIES

Utillty or Energy Transmisslon Corridors and Facilities: $230 \mathrm{KV}$ powerline, two miles west of site.

Transportation Corridors or Facillities: U.S. 287 and Wyo. 28 nearby. Site is 10 miles south of Lander.

\section{POPULATION}

General Description of Population: The population in the vicinity of the site is very small, made up of ranchers until you get within a mile or so of Lander. 90\% white, 10\% native american. Employed in ranching, mining, government, retall, and lumber.

\section{Economics:}

Present Land Use: Greenhouse and ranching.

Future Land Use: Greenhouses, ranching, and potential space heating. 


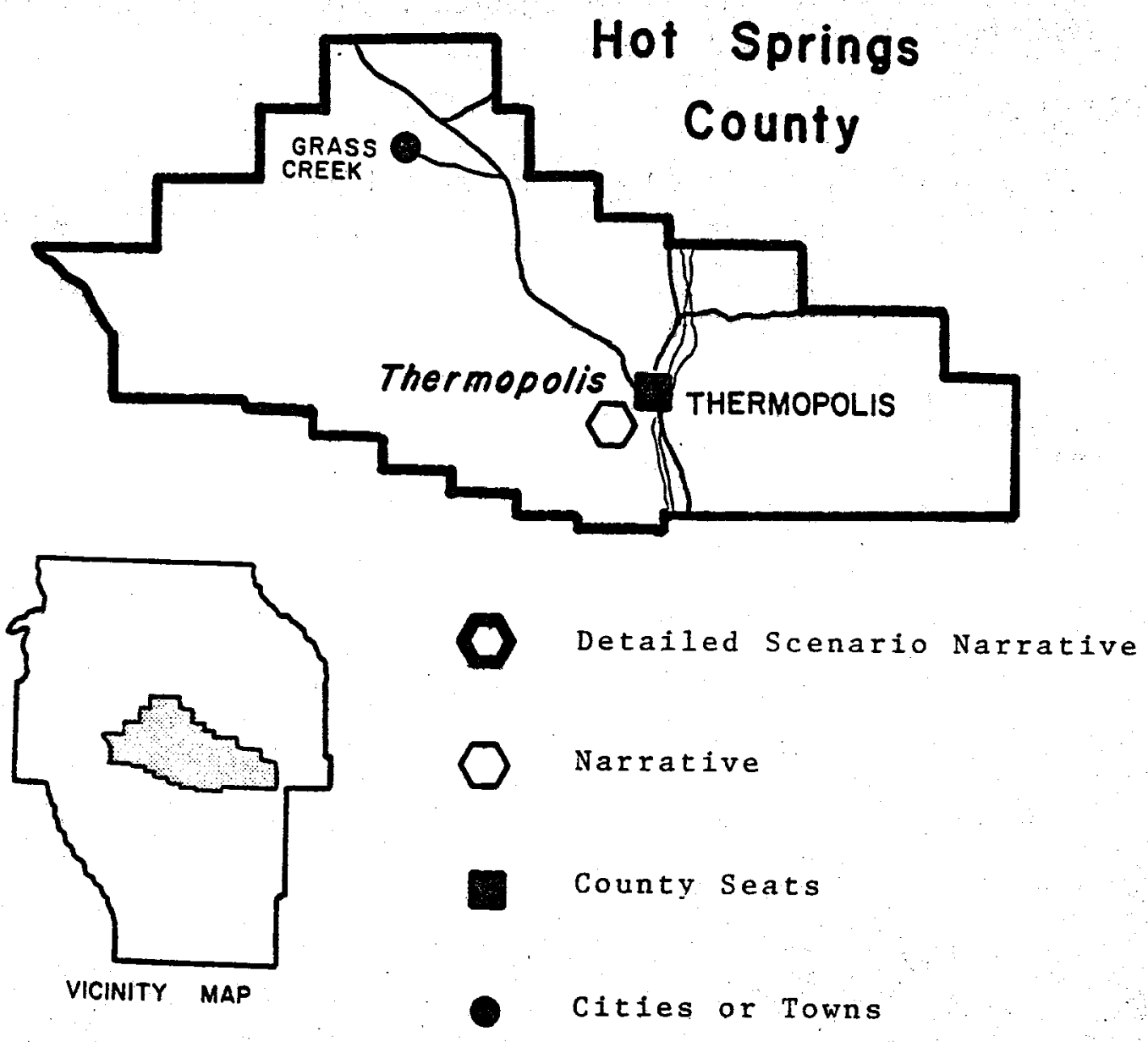


Subchapter $11-3$ Thermopolis

Hot Springs State Park in Thermopolis is the most famous thermal area in Wyoming outside of Yellowstone. The springs have been noted for thelr reputed curative properties for years, being first used extensively by native Americans since prehistoric times. The springs were originally included in lands ceded to the Shoshone and Bannock tribes by the 1868 Fort Bridger Treaty. A 55,040 acre tract, Including the springs, was purchased by the federal government in 1896 and the following year a full section around the center of thermal activity was given to the state of Wyoming. A 1937 purchase of an additional 291 acres resulted in the present Hot Springs State Park. The Park contalns several pools, two commerclal swimming pools, the State Bathhouse, and a variety of terrace deposits (Breckenrldge, 1978, p.25).

Being part of the state park, the speciflc springs Identifled in Table 11-l wlll be treated with no proposal being made for their potential development. The springs of the park are a major factor in the economy of Thermopolis, being used for tourism and recreational purposes as well as belng the focal point for several health facllities.

The privately owned wells in the Thermopolis area offer significant space heating potentlal. The three wells are or have been used to heat the homes and swimming pools of the owners in the past. If we were to apply a reasonable $\Delta T$ (amount of heat which can be extracted) such as $30^{\circ} \mathrm{F}$., we can realize significant space heating potential as indicated in Table 11-2.

TABLE $\mid 1-1$

Hot Springs State Park Springs

\section{Spring}

Bathtub Spring

White Sulphur. Spring

Pilling Spring

Black Sulphur Spring

Terrace Spring

Big Spring
Temperature

$53^{\circ} \mathrm{C} .\left(127^{\circ} \mathrm{F}\right)$

$53^{\circ} \mathrm{C} .\left(127^{\circ} \mathrm{F}.\right)$

$35^{\circ} \mathrm{C}$. $\left(95^{\circ} \mathrm{F}.\right)$

$55^{\circ} \mathrm{C} .\left(131^{\circ} \mathrm{F}\right)$

Not measured

$56^{\circ} \mathrm{C} .\left(133^{\circ} \mathrm{F}.\right)$
Flow

$2 \mathrm{gpm}$

$206 \mathrm{gpm}$

Less than $3 \mathrm{gpm}$

Little or none

$10 \mathrm{gpm}$

$2908 \mathrm{gpm}$

(Information collected from Breckenrldge; 1978).

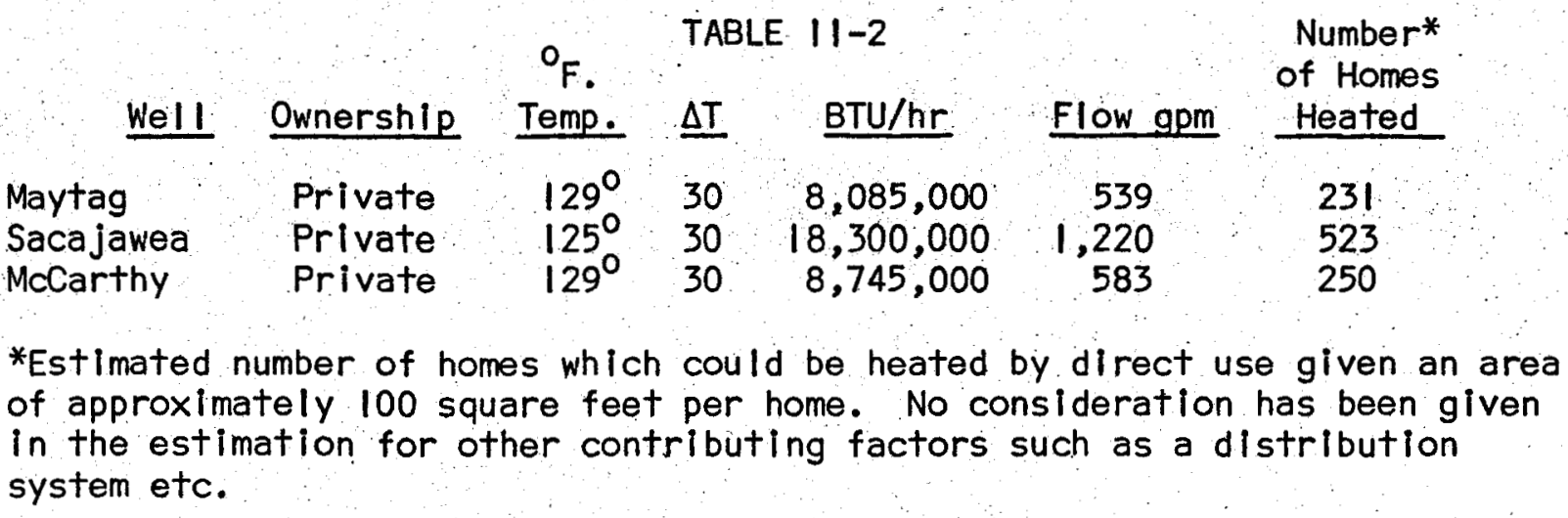

(Some Information gathered from Breckenridge, 1978). 


\section{Subchapter $11-4$}

Additional thermal manifestations occur throughout Region 1. These springs have not been treated in detall, but the pertinent information is summarized in Table $11-3$. Nearly all of the springs in this region indicate direct use of heat pump potential. 
TABLE $\|-3$

Regional Thermal Springs

\section{Spring Name}

Sheep Mountain Springs

Conant Creek Springs

Ft. Washakie Hot Springs

Jakeys Fork Spring

Little Warm Spring

Sweetwater Station Spgs.

Warm Spring Creek Spgs.

Wind River Canyon Spgs.

DeMaris Hot Springs

\begin{tabular}{|c|c|}
\hline $\begin{array}{l}\text { Temp. } \\
{ }^{\circ} \mathrm{C} .\left(\mathrm{O}_{\mathrm{F}}\right)\end{array}$ & Flow \\
\hline $\begin{array}{l}21^{\circ} \mathrm{C} .\left(70^{\circ} \mathrm{F}_{.}\right) \\
16^{\circ} \mathrm{C} .\left(61^{\circ} \mathrm{F}_{-}\right) \\
44^{\circ} \mathrm{C} .\left(111^{\circ} \mathrm{F}_{.}\right)\end{array}$ & $\begin{array}{l}450 \mathrm{gpm} \\
300 \mathrm{gpm} \\
150 \mathrm{gpm}\end{array}$ \\
\hline 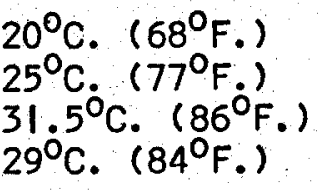 & $\begin{array}{r}4 \mathrm{gpm} \\
560 \mathrm{gpm} \\
500 \mathrm{gpm} \\
133 \mathrm{gpm}\end{array}$ \\
\hline $\begin{array}{l}22^{\circ} \mathrm{C} .\left(72^{\circ} \mathrm{F}_{.}\right) \\
33^{\circ} \mathrm{C} .\left(88^{\circ} \mathrm{F} .\right)\end{array}$ & $\begin{array}{r}989 \\
1700\end{array}$ \\
\hline
\end{tabular}

County

Big Horn.

Fremont

Fremont

Fremont

Fremont

Fremont

Fremont

Hot Spgs.

Park
Ownership

BLM

Private

Wind River

Indlan Res.

Private

Private

Private

BLM

(Lease-Harrison)

Private

Private
Location

Sec. $23, T 54 N, R 94 W$.

Sec. 26, T33N, R94W.

Sec. 2, T IS, R IW.

Sec. 29, T41N, RI06W.

Sec. 14, T4IN, RI07W.

Sec. 15, T29N, R95W.

Sec. 32, T42N, R107W.

Sec. 25, T42N, R95W.

Sec. 3, T52N, RI02W.

(Information gathered from Breckenridge, 1978). 
CHAPTER III

The Powder and Bell Fourche RIver Basins

Region 2
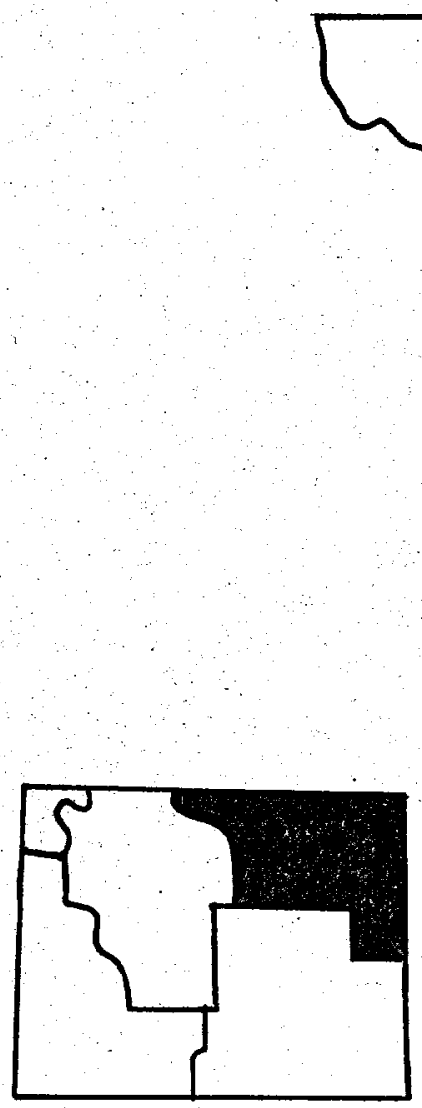
Region 2, The Powder and Belle Fourche River Basins, is the northeastern region. The most significant regional feature here is the extensive Powder River Bas in and the accompanying Thunder Basin. The Big Horn Mountains border the region on the west and the Black Hills on the east with the Thunder Basin National Grassland to the south.

The region is located in the northeastern corner of the state and its six counties contain about 15\% of Wyoming's population. The counties are Johnson, Sheridan, Campbell, Crook, Weston, and Niobara. Although these counties do not exhibit any natural surface manifestation of geothermal activity, they do overlle the largest deep water bearing formation in the state. Many wells have been drllled into this massive limestone formation, The Madison Formation. Some of these wells reportedly have exhibited remarkable flows and temperatures. It is expected that thermal resources discovered in this region would emanate from the Madison, clearly ranking as a significant geothermal resource. Detalled information on the Madison Formation can be found in Appendix A. However, no specific geothermal resource site nor hot spring can be addressed which could illustrate the suspected geothermal potential in the region. 
CHAPTER IV

The North Platte River Basin
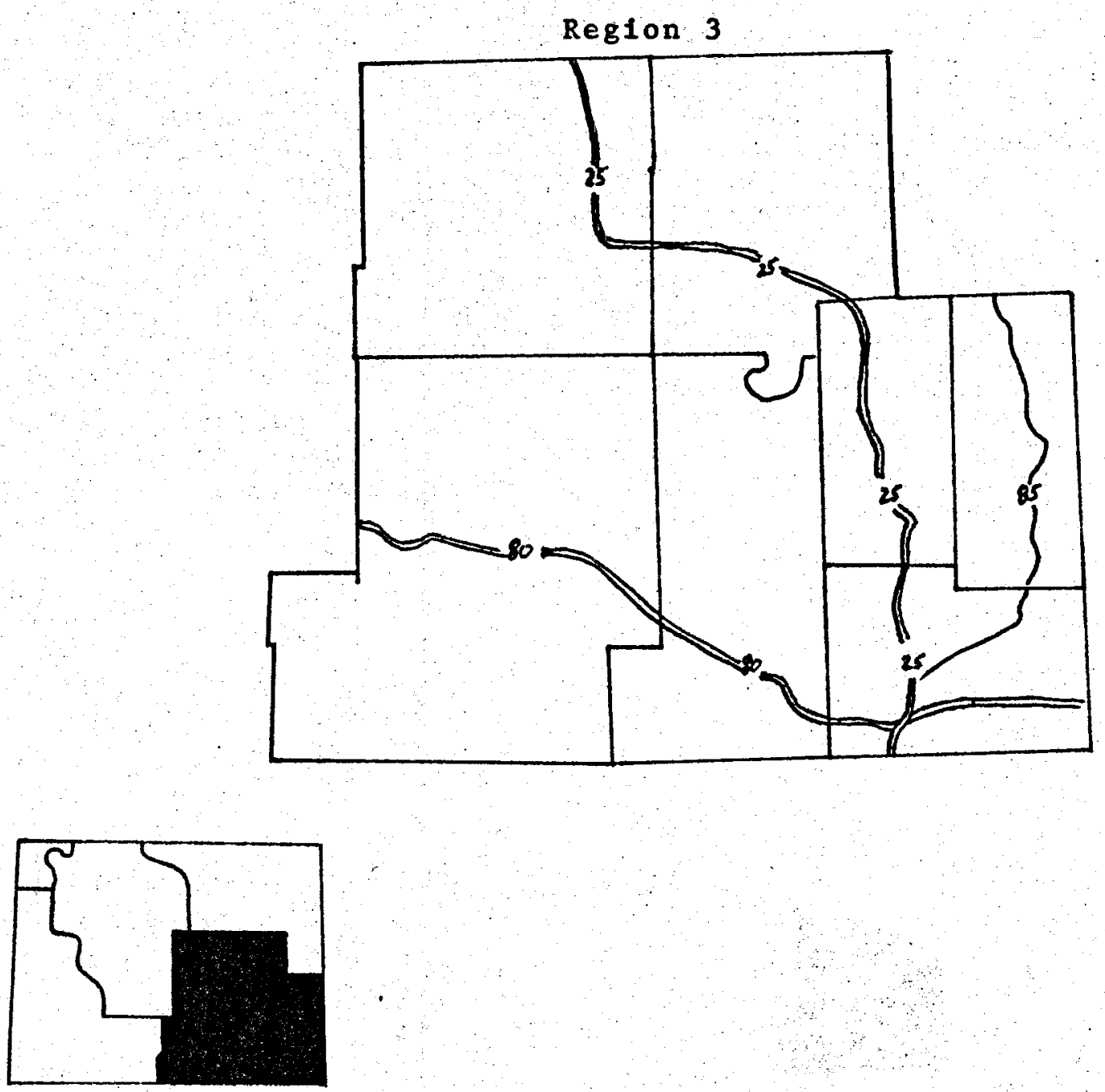

Subchapter

Site

Proposed Use

Treatment

IV -1

Saratoga

District Heating

Scenario

IV -2

Midwest/Salt Creek

Greenhouse Complex

Scenario

IV -3

Glenrock

011 Processing

Discussion

IV -4

Thermal springs

None

Inventory 
Region 3, The North Platte River Basin, makes up the southeast quarter of Wyoming. The North Platte River loops around the Laramie and Snowy Ranges and through five of the seven counties of the region. This is the most developed, diverse, and populous region with the three largest cities of the state and a stable economic base. It also has geothermal promise as it contains four areas identified as having prospective value for geothermal development and borders on the edge of the Madison Formation.

The region contains the counties through which the North Platte River and its tributaries flow. Located in the southeastern corner of Wyoming and bordered by Colorado and Nebraska, the region contains the three largest cities and 51\% of the state's population. The counties of Natrona, Converse, Platte, Goshen, Laramie, Albany, and Carbon make up this area. Interest has been shown by residents of the towri of Saratoga who would like to develop their thermal resource and have proposed a community recreation center. This could be a first step toward the development of a district heating system for the town. The initial portion of this chapter will be on Saratoga and a major resource being used at Midwest in water flooding projects will be treated next. The significant volumes of warm and hot water from this resource lead to a number of development possibilities. Another water flooding project at Glenrock is treated briefly, in this case it is of interest because of its use of geothermal fluids for oil treatment. A discussion of other thermal springs in the region is included. 
Subchapter IV-I Saratoga

The town of Saratoga is located on the alluvlal plain of the North Platte RIver between the Sierra Madre Mountains on the west and Snowy Mountain Range on the east. The valley broadens to the north and is known as the Saratoga and Encampment Valley. Saratoga is presently the second largest community in Carbon county with a population of 2,450 . However it was originally a trading community for fur traders and trappers in the early $1800^{\circ} \mathrm{s}$. Later discoveries of varlous minerals, principally copper, led to further development of the valley. The clty was incorporated in 1900 but soon, several disasters forced one of the nation's important copper producing areas into bankruptcy (Saratoga Land Use Plan, 1977).

Since the first settlement of the valley, sawmills have been Important to the local economy and in the mid-1960's the Edward Hines Lumber Company constructed a sizable sawmill at Saratoga which contributes significantly to the community's economy. Coal development near Hanna In the early $1970^{\prime}$ s has brought many new residents to Saratoga who prefer to live there and commute 45 miles north to Hanna.

The Hobo Pool, adjacent springs and wells, are all located in the Immediate vicinity of both the downtown area of Saratoga and the North Platte River. The Hobo Pool was orlginally used by Indlans before it was discovered by white pioneers who named it Warm Springs (Breckenridge, 1978 p. 13). In 1886, Fennimore Chatterton named the town Saratoga after the hot springs in New York State. Saratoga soon developed a resort industry to compliment its trading and supply economies. In 1921, the state purchased a 420 acre parcel of ground including the hot springs, which became known as Saratoga Hot Spring Reserve. A small swimming pool and a resort were developed and later leased to a private corporation. In 1961, the state legislature sold the reserve to the corporation leasing the property. The Saratoga Inn was constructed by the state and continues as the center of Saratoga's tourlst Industry (Saratoga Land Use PIan, 1977).

The Hobo Pool is the principle spring at Saratoga and flows $120 \mathrm{gpm}$ into a dirt-bottomed bathing pool levied up with masonry. It was walled in by the Civillan Conservation Corps in the 1930's to keep the North Platte River from flooding the spring. A well near the spring supplles pumped water to a large publlc swimming pool bullt from donations in the $1950^{\prime}$ s (Personal communication, Fred Sipe, 10/78).

Four other springs appear on the edge of the river. Three of them are enclosed in concrete pools or enclosures, the fourth is a serles of seeps across from the Hobo Pool.

Two more hot wells exist in Saratoga, the first is the well at the Frank Nixon residence which supplies hot water to a small swimming pool. The Saratoga Inn also owns a well from which hot water is pumped to a commercial swimming pool (Breckenridge, 1978).

Today the land-use for residences beyond the downtown area is initially single family housing and then ranches further out. It should be noted that the downtown area includes apartments, municipal bulldings, schools, churches, commerclal development, as well as some single family housing. 
50

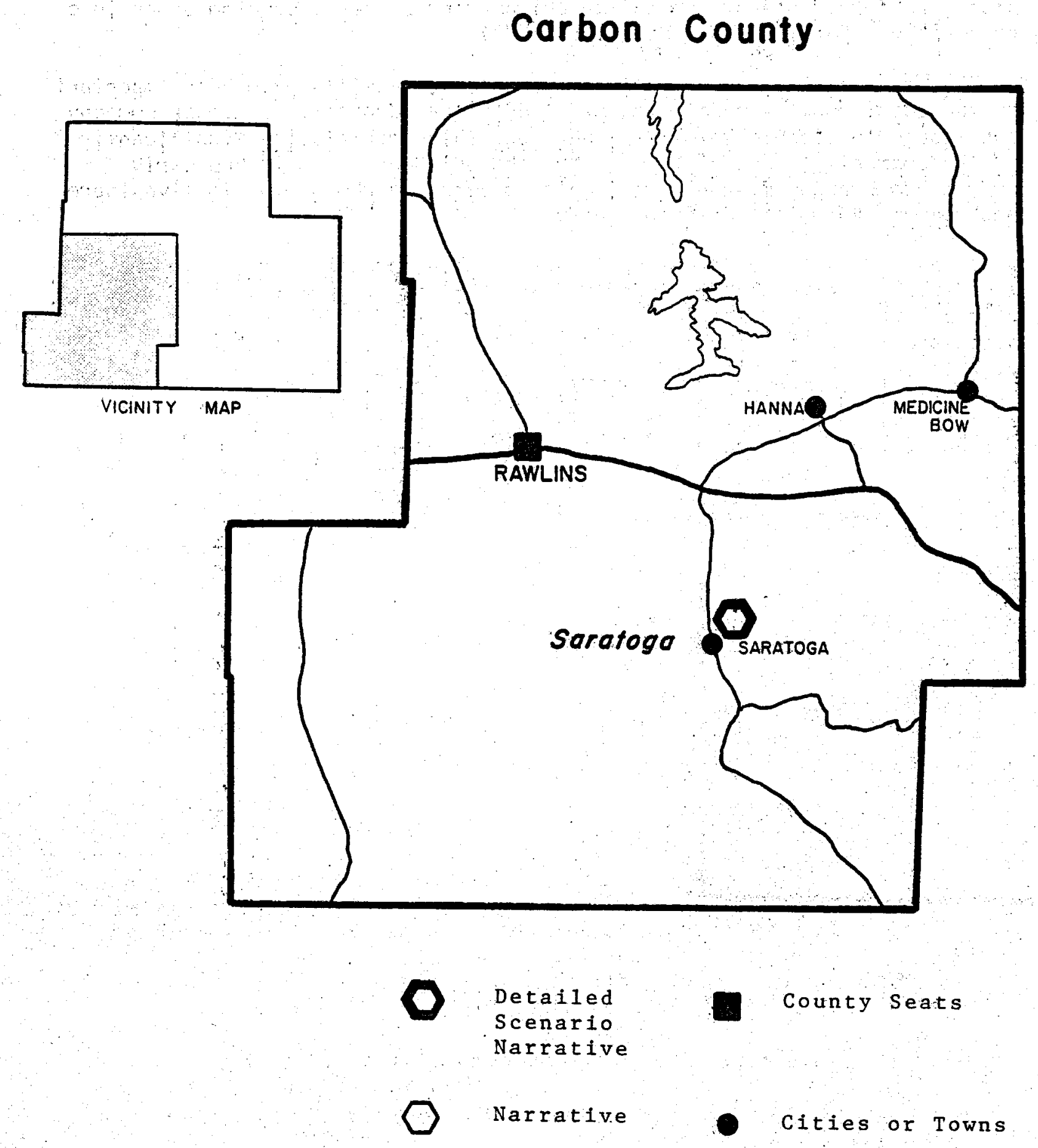


All of the Saratoga thermal waters seem to be surface manifestations flowing from the Niocene North Park Formation and overlying al luvium. Although both the size and source of the reservoir must be considered as unknown at this time, several attempts have been made to explain the source of the springs in Saratoga.

\section{TABLE IV-}

Geothermal Springs and Wells In Saratoga

$\begin{array}{cccc}\text { Name } & \text { Ownership } & \text { Temp. } & \text { Flow } \\ \text { Hobo Pool \& Well } & \text { Town of Saratoga } & 48^{\circ} \mathrm{C} & 120 \mathrm{gpm} \\ \# 2 & \text { Unlon Pacific RR } & 48^{\circ} \mathrm{C} . & 3-5 \mathrm{gpm} \\ \# 3 & \text { Saratoga Inn } & 43^{\circ} \mathrm{C} & \text { Very Small } \\ \# 4 & \text { Saratoga Inn } & 48^{\circ} \mathrm{C} & \text { Undetermined } \\ \# 5 & \text { Bellamy } & 54^{\circ} \mathrm{C} . & \text { Pumped } \\ \# 6 & \text { Unlon Paciflc RR } & 30^{\circ} \mathrm{C} & \text { None }\end{array}$

(Information from Breckenridge, 1978 pp.13-15).

\section{District Heating for Saratoga}

District Heating is a concept that is relatively new to Wyoming although a steam heating district did once exist in Cheyenne. Their system consisted of a centrally located boller from which steam was piped to the bulldings of the downtown area. The system was abandoned several years ago and heating with natural gas has replaced steam.

District Heating is simple in concept and the application of geothermal fluids to this use in other communities would only be restricted by possible limitations of temperature and flow rate in an individual resource. The Saratoga situation is a site specific case which may be considered as a generalized distrlct heating model for similar resources in Wyoming.

Geothermal distrlct heating is unique in that the heating district must be reasonably near the geothermal resource, while carefully considering the character of the particular reservolr being tapped. One must also pay attention to the needs and resources of the community. Often, district heating is phased over several years to accomodate gradual assessment of the resource and the development of financing potentials.

A geothermal district heating system usually has several components: (1) resource, (2) well, (3) heat extraction system, (4) delivery system, and (5) space to be heated. These components will be addressed one at a time for Saratoga.

1. The Resource. We are aware of a series of springs and wells with a NNE to SSW altitude in Saratoga. The most apparent of these is the Hobo Pool with its unlque Importance to the Saratoga community as a tourist attraction. With the use of geothermometry, the temperature can be determined within bounds at depth. It should be noted here 
that silica geothermometers have consistently predicted hotter temperatures than eventually are found. Silica geothermometry is used as best avallable information for predicting temperatures at depth. The most recent analysis of the Hobo Pool, in 1976 (Breckenridge, 1978), reports a silica content of $63 \mathrm{ppm}$. The geothermometer thus indicates a reservoir temperature of $120^{\circ} \mathrm{C} .\left(248^{\circ} \mathrm{F}.\right)$ and any temperature greater than $88^{\circ} \mathrm{C}$. ( $190^{\circ} \mathrm{F}$.) is sufficient for district heat use. It is important to know how far the resource is from the site of utilization, how many square feet will be heated, and will the geothermal fluid be removed from the well to be discharged later or will it be reinjected.

2. The Well. Saratoga has a small but apparently adequate artesian well which is adjacent to the Hobo Pool and pumped to the municipal pool about thirty feet away. Some mixing of cooler ground water is suspected in the well which issues at approximately $48^{\circ} \mathrm{C}$. $\left(118^{\circ} \mathrm{F}.\right)$.

For one or two bulldings, the existing well would probably be adequate for heating, but as the need for more heat increases with more buildings being. included in the heating district, more wells would need to be drilled.

The process of drilling additional wells should be done by competent drillers and supervised by engineers and geologists. The resource is probably available and it is assumed that it is not significantly deep. There has been concern regarding additional drilling of wells in Saratoga. Considering this concern, the town commissioned a study by Donley in March 1978. The study was made to evaluate the potential danger of blasting in the area of the Hobo Pool. The report of that study indicated," "The ledge rock is too hard to permit removal without jack hammering or blasting. The ledge rock is bedded very nearly horizontally so would require only very small, well controlled time-delay blasting techniques..." "It is our opinion that the small, well controlled time-delay type of blasting. would not be detrimental to the Hobo Pool. However, massive blasting could cause a locallzed structural shifting that might cause the subterranean hot water to surface elsewhere."

From the above information it could be assumed that additional drilling under controlled conditions would not be harmful to the Hobo Pool: Therefore, for an expanded heating district of more than two bullding, new wells would be necessary and could be assumed possible without being harmful to the Hobo Pool.

3. Heat Extraction System. A number of heat extraction methods are available depending on the well temperature, economics, and construction/retrofitting problems involyed. The following four methods have been extracted from Lienau, Culver, and Lund, 1977 .

A. Direct use of the geothermal fluid where the actual well water is piped through the entire system. This consists of demand controlled producing well(s), supply lines, the direct utilization of the geothermal fluid in each bullding, and waste lines to reinjection well(s). B. Paraflow central plate type well-head Heat Exchanger using city water as the secondary fluid. This 
consists of demand controlled producing well(s), supply IInes, the direct utllization of the geothermal fluid in each bullding, and waste lines to reinjection well(s).

B. Paraflow Central plate type well-head Heat Exchanger using clty water as the secondary fluid. This consists of demand controlled producing well $(s)$, central heat exchanger, and reinjection well(s) on the primary side of the heat exchanger. City water is heated by the geothermal fluid at the central heat exchanger, supplled to the bulldings, and returned to the heat exchanger by parallel transmission Iines.

c. Downhole Heat Exchanger systems consisting of wells with closed loop plpe heat exchangers using city water as the secondary fluld. This system would require insulated supply and return transmission lines due to the low efficlency of the exchangers. Current research may improve this efficlency. which is now estimated at 10 percent of that obtained by direct use.

D. Individual Building Heat Exchangers using clty water as the secondary fluld in a closed loop within each bullding. Demand controlled pumps, supply, and waste transmission IInes and reinjection wells are required as in the direct use system.

4. The Delivery System. This system will depend largely on the slze of the district. Basically, it will contain a pumping mechanism and a series of insulated pipelines.

The plpe would be asbestos cement plpe with sllp-type jolnts, these are especially advantageous since they reduce installation costs.

5. Space to be Heated. The community recreation center that the town of Saratoga is currently planning is nearly 30,000 square feet of bullding and contains an olympic swimming pool. The pool will act as a thermal mass holding great amounts of heat whlch would also cause the disadvantage of making the bullding very humid unless great volumes of air are moved through the bullding while heating it.

The recreation center promises to be the first geothermally heated municlpal bulldings in Saratoga and the first link In a chain of buildings heated geothermaliy in a community heating district. It may be completed as early as 1980 beginning the process in Saratoga of saving precious fossil fuels for other localities where the option of alternate energy sources is not avallable. 
GEOTHERMAL ENERGY EVALUATION

NON-ELECTRIC GEOTHERMAL ENERGY APPLICATIONS

SITE: SARATOGA

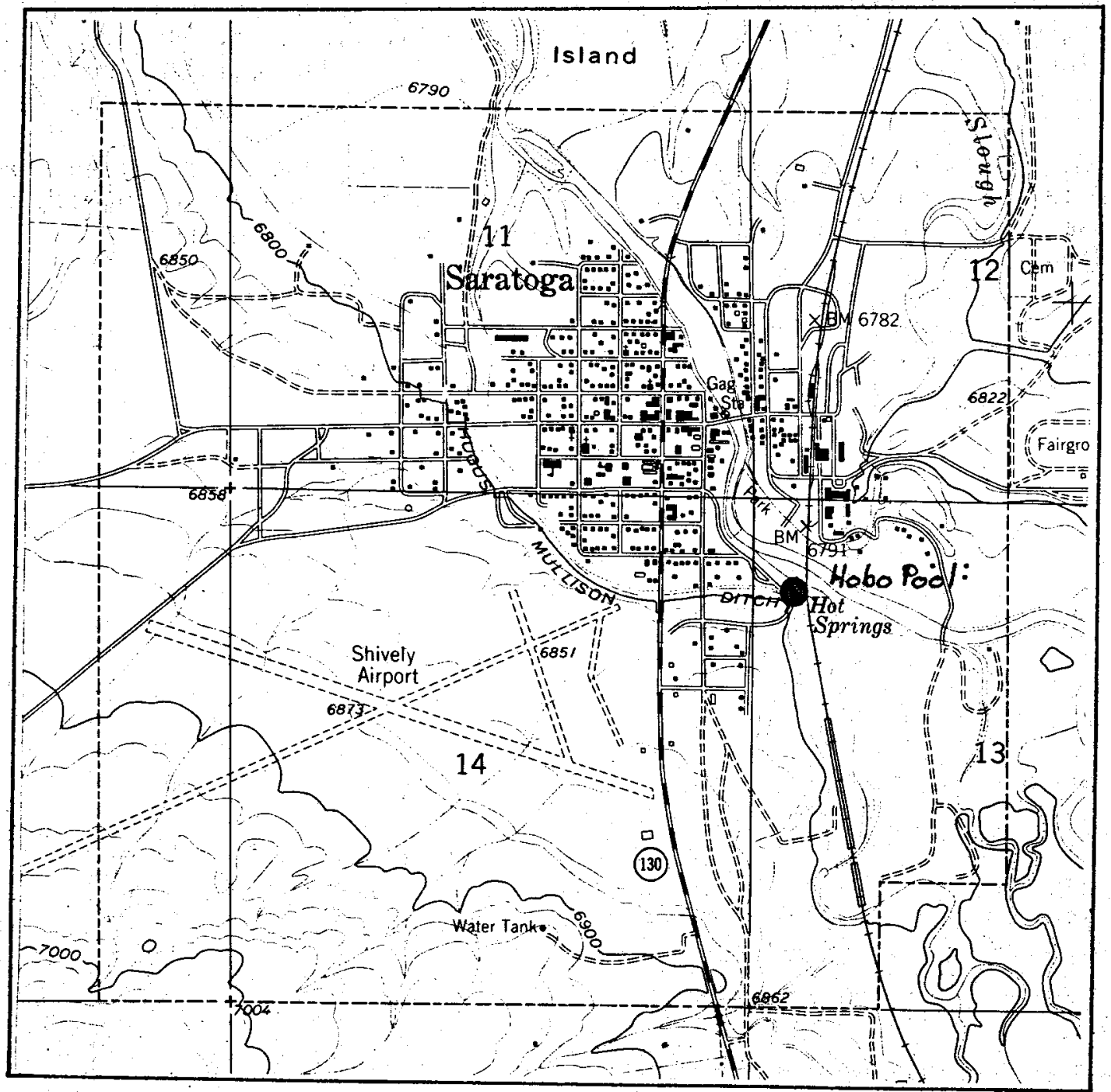

(Base map from USGS Saratoga Quadrangle, Wyoming - Carbon County, 7.5 Minute Series, Topographic, 1961). 


\author{
GEOTHERMAL ENERGY EVALUATION \\ NON-ELECTRIC GEOTHERMAL ENERGY APPLICATIONS
}

SITE: Saratoga

HOBO POOL

Physical Reservoir Data:

Temperature: Surface $48^{\circ} \mathrm{C}$; Subsurface $120^{\circ} \mathrm{C} .\left(\mathrm{S} \mathrm{O}_{2}\right)$

Total Dissolved Sollide (PPM): 1920

Estimated Non-Electrlc Energy Potentlal (MBtu/h, 30 years): No estimate. Type of Overlaying Rock: Mlocene over Mesozolc and Paleozolc/North

Park Formation. Tuff, sandstone, claystone.

Estimated Depth to Top of Reservolr (meters): Unknown.

Site Land Status:

Total Acres: State ownershlp of 15.34 acres leased to town for 99 years. Total Acres Leased: 15.34 acres, lease expires in 2040.

Geothermal Development Status:

Use of Hobo Pool for a swimming pool and heating community pool proposed recreational bullding with swimming pool.

Local and State Attitude Toward Geothermal Development:

The local Recreation Board is very pro-development of geothermal. The state is occupied with oll, gas, coal, and uranium as their prime energy sources at this time.

Land Use and Population:

Currently a recreational spot is on the shore of the North Platte River within $1 / 4 \mathrm{mile}$ of the town and 100 yards of other bulldings and homes.

\title{
SITE LOCATION AND PHYSICAL DESCRIPTION
}

Latitude:

Longitude:

Rectillinear:

County:

Adjacent Counties:

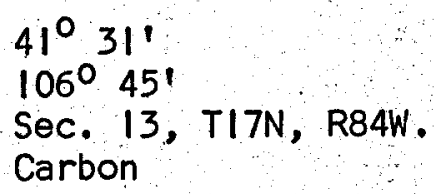

$41^{\circ} 31^{\prime}$

$106^{\circ} 45^{\prime}$

Sec. 13, TI7N, R84W.

Carbon

Natrona, Sweetwater, Albany--Wyoming; Jackson and Routt-Colorado

Topography: The general topography is flat and only a few (10') feet above the North Platte River. The town rises gradually on both east and west banks of a $1 / 2 \mathrm{mile}$ wide alluvial plaln.

Present Land Use: Recreation, municipal pool. 
Future Land Use Plans: Recreation center with municipal pool.

Aesthetics: Close to town but away from traffic, on the shore of the North Platte River. Nice sounds and view of river, trees on or near property.

Historical/Archaeological Significance: Reportedly originally used by Indians. In 1886 it was called "Warm Springs" by Fennimore Chatterton and named Saratoga after the New York state health resort. Mineral properties of Saratoga water "discovered" in 1911 and was later sold as "radioactive" mineral water nationwide.

Geological/Geophysical Description:

Geologic Description: Springs flow from the Miodene North Park Formation and overlying alluvium to the surface via a fault which runs NNE. to SSW.

Geophysical Summary: Silica geothermometry based on chemical analysis taken during a span of time from 1900 to 1976 varies as indicated below.

\begin{tabular}{|c|c|c|}
\hline Year & $\mathrm{SiO}_{2}$ & Temperature $\mathrm{C}$. \\
\hline $\begin{array}{l}1900 \\
1926 \\
1967 \\
1976\end{array}$ & $\begin{array}{r}125.0 \\
63.7 \\
62.0 \\
63.0\end{array}$ & $\begin{array}{l}150 \\
115 \\
112 \\
114\end{array}$ \\
\hline
\end{tabular}

Geologic Hazards: Flooding potential.

RESERVOIR CHARACTERISTICS

Saratoga Hobo Pool

Reservoir Temperature: Surface $48^{\circ} \mathrm{C}$.; Subsurface $114^{\circ} \mathrm{C} .\left(\mathrm{SiO}_{2}\right)$

Flow Rates: $120 \mathrm{gpm}$

$\mathrm{pH}: 8.9$

Total Dissolved Solids: 1920 ppm

Fluid Chemistry:

$\begin{array}{llll}\mathrm{Ca} & 140 \mathrm{ppm} & \mathrm{F} & 6.1 \mathrm{ppm} \\ \mathrm{Mg} & 11 " & \mathrm{~S} & .075 " \\ \mathrm{Na} & 450 " & \mathrm{SiO}_{2} & 63 \mathrm{n} \\ \mathrm{K} & 23 " & \mathrm{~B} & 1.7 \mathrm{n} \\ \mathrm{CO}_{3} & 24 " & \text { TDS } & 1921 " \\ \mathrm{HCO}_{3} & 130 " & \text { Hard } & 380 " \\ \mathrm{SO}_{4} & 570 " & \text { Total } \mathrm{CO}_{3} & 87 \mathrm{n} \\ \mathrm{Cl}^{2} & 540 " & \mathrm{pH} & 8.9 " \\ \mathrm{NO}_{3} & 0 \mathrm{n} & & \\ \text { (Breckenridge, } & 1978) & & \end{array}$


Subsurface Area of Reservoir: The hot spring is assumed to be a surface manlfestation of the reservoir which finds its way to the surface through faulted rock and surface alluvium. The actual size of the reservoir is unknown at this time.

\section{LAND OWNERSHIP AND LEASING}

Total Area in Acres: 15:43, State of Wyoming

Summary of Leasing Status and Needs: The land at the Hobo Pool is leased by the town of Saratoga from the state on a 99 year lease whlch explres in 2040.

\section{GEOTHERMAL DEVELOPMENT STATUS}

Present Development Status: Currently being used by community for a municipal pool and an open pool at the spring itself.

Projected or Planned Development: Plans are underway to develop a geothermally heated community recreation center with Olymplc pool and sauna.

\section{INSTITUTIONAL CONSIDERATIONS}

Institutional

Requilrements.

Bullding Codes

Zoning

Water Rights

Geothermal Use
Agency and

Public Attitudes

Town of Saratoga:

Public opinion is

divided, some are

in favor of

developing the

Hobo Pool while

others fear that

development may

damage the spring

County Planning

State Eng.

State Land Office

ENVIRONMENTAL FACTORS

Climate: Prevalling Winds: Westerly, downslope

Precipltation (annual); Seml arld, 9.27 inches

Days of Sunshine (annual); 300

Average Temperature; Minimum $27.7^{\circ} \mathrm{F}$. Maximum $57.5^{\circ} \mathrm{F}$.

Blological: Dominant Flora; Sage, Prairle grasses, cottonwood along river bank

Dominant Fauna; Antelope, prairie dogs

Endangered Specles of Fauna; raptors, blackfooted ferret

TRANSPORTATION AND UTILITIES

Utility or Energy Transmission Corrldors and Facilities 


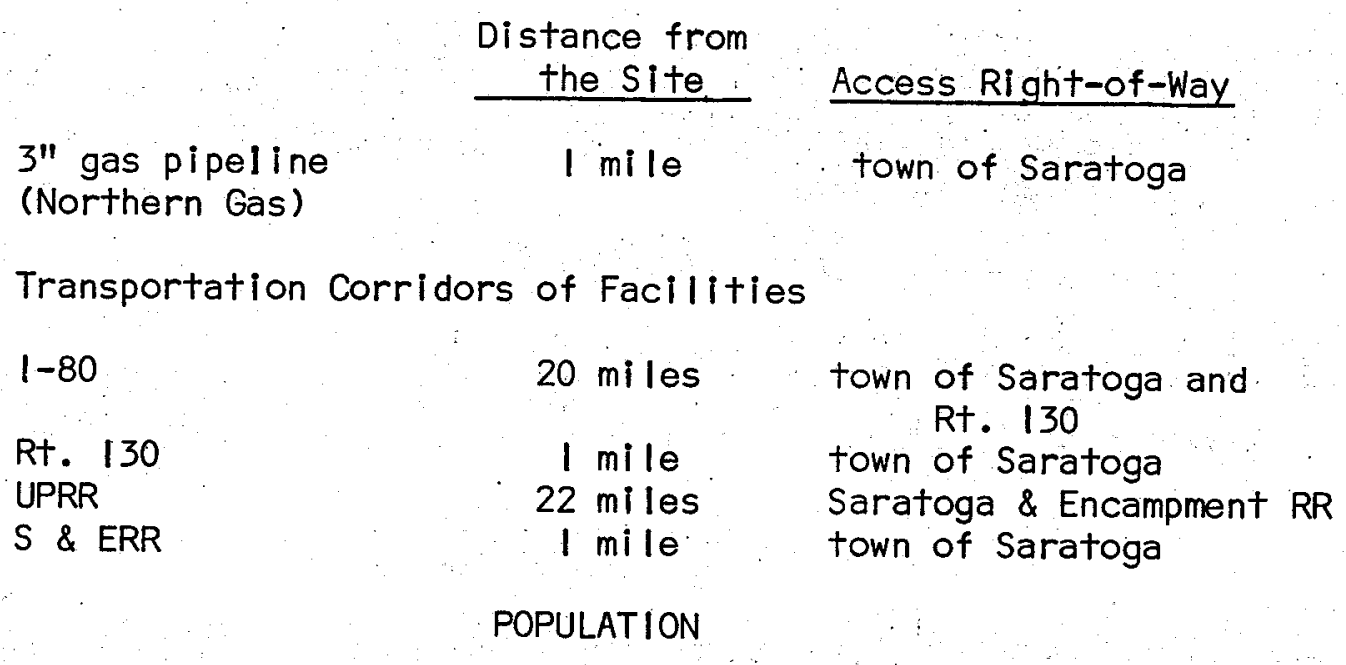

General Description of Population: Saratoga; $98 \%$ white, $2 \%$ Mexican American. Employed in ranching, mining, and retail and lumber.

Economics: Present Land Use; Community is expanding at a rapid rate as a result of mining in the area. The small farms and ranches at the outer edges of town find themselves becoming subdivisions to satisfy the need for adequate housing.

Future Land Use; It is anticipated that the town will continue to grow through the year 2000, putting a greater strain on the housing needs. 


\section{Natrona County}
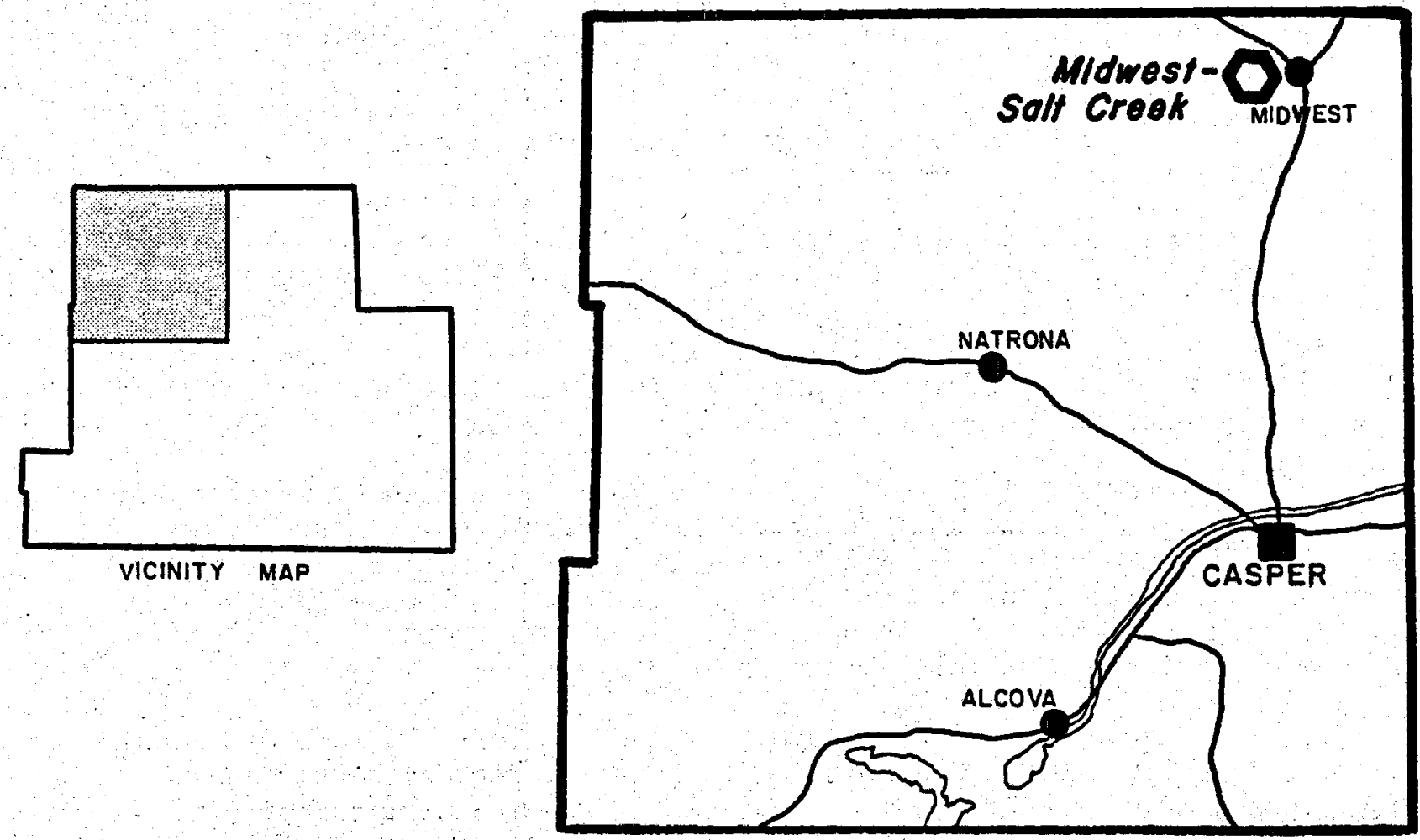

0

Detalled

Scenario

County Seats

Narrative

D Narrative

- Citles or Towns 
Subchapter IV-2 Midwest/Salt Creek.

Midwest is situated at the northeastern corner of Natrona County and is about 40 miles north of Casper. Midwest, whose population of nearly 1,000 is larger than its neighbor one mile to the east, Edgerton, with 400 residents. There are several major oil fields in the Midwest area. The Salt Creek field, currently the most productive, has been producing oll for many years. Ten miles southeast, the Teapot Dome field received national attention during the 1920 's as a scandal developed around its development. The US Navy now controls the reserve there and the field has limited production. Most of the oil fields in the area use waterflood procedures to enhance their production. Amaco's operation at Midwest is a good example of this process.

Midwest, lying forty miles north of Casper and 110 miles south of Sheridan, was just a stop to water the horses prior to the discovery of oll in the early part of this century. Oil is the economic base of the area and nearly all of the workers are employed in the oil fields. The only other businesses are supportive of the oil industry.

In the early 1960's, wells were drilled to find water to be used for waterflooding projects. Waterflooding is a process for additional oil extraction where a large volume of water is injected into the oil bearing rocks to "wash" out the oll and float it to the surface. This lengthens the life of the oll field and allows an otherwise depleted resource to continue to be productive."

The wells that were drilled, tapped large volumes of water from the Madison Formation. This large aquifer is a deep, massive deposit of limestone which lies beneath all of the Powder River Basin. Wells throughout the basin have penetrated the Madison as well as the Tensleep Sandstone which overlays it. Some of these wells are used for oil and natural gas production while many are producing water for waterflood projects.

The Salt Creek field is of interest as both the volume of water being used and its temperature are significant as a geothermal resource. The temperature of the water is approximately $100^{\circ} \mathrm{C}$. which benefits the waterflood process as it thins the crude oil and allows it to be extracted more easily. Also, the hot water is used to assist in the separation of gases and solids from the crude oil. (see Subchapter $111-3$ )

The Salt Creek wells, which have an artesian flow of 14,583 gpm, and a temperature of $93^{\circ} \mathrm{C}$, are a potential resource worthy of development. Many types of development might be considered from the development of a heating district for the towns of Midwest and Edgerton to the raising of prawns through geothermal aquaculture.

An alternate industry in the Midwest area could produce positive results. It would tend to diversify the local economy making it less dependent on the area's single industry.

A feasible application would be to encourage the relocation of the carnation growing industry. to Midwest. The industry could take advantage of the geothermal resource for heating their greenhouses. Greater Denver 
is a major growing region for carnations at this time. High fuel costs, among other factors have reduced the profit margin of the industry significantly in recent years. Midwest is only $300 \mathrm{ml}$ les from the known market in Denver and only $245 \mathrm{ml}$ les from Blllings, another potentlal market. Shipping the carnations by truck could be relatively near the Interstate Highway with a direct route to Denver or Blillings.

Greenhouses are simple structures with known needs and are easily constructed in a group. The Information on their construction and development is widely known and avallable. A greenhouse fitted geothermally could rely on heating the air with large fans which blow alr across coll radiators or heat exchangers containing the geothermal fluid and then through one of a varlety of duct systems for distribution throughout the greenhouse.

The geothermal fluid might be purchased from the oll company operating nearby and after it is used and needed heat extracted, returned to the company for reinjection in the waterflooding project. 
GEOTHERMAL ENERGY EVALUATION

NON-ELECTRIC GEOTHERMAL ENERGY APPLICATIONS

SITE: MIDWEST/SALT CREEK

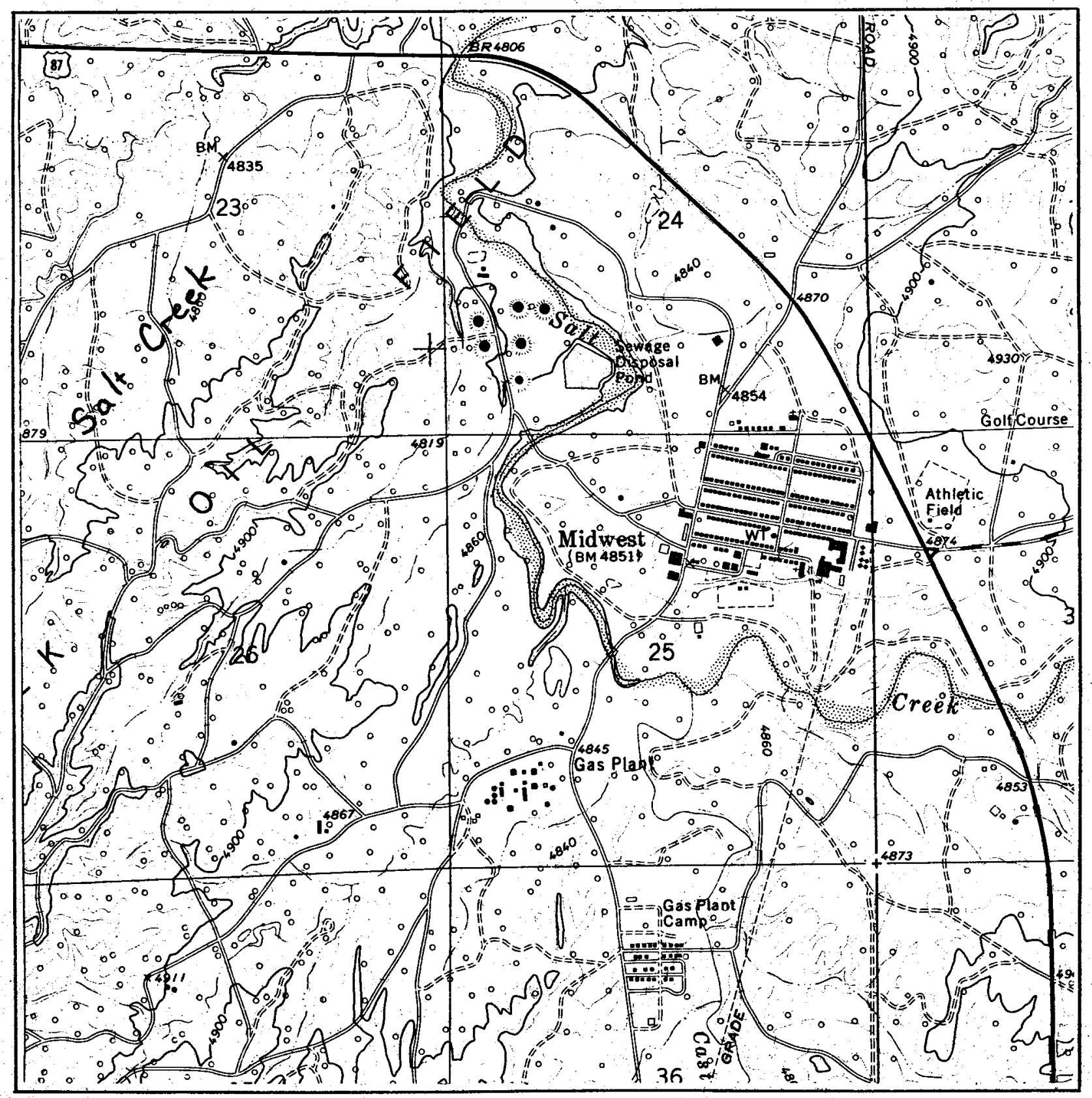

(Base map from USGS Midwest Quadrangle, Wyoming, 7.5 Minute Series, Topographic, 1968). 


\section{SITE DATA SUMMARY \\ Midwest/Salt Creek}

Physical Reservolr Data:

Temperature: Surface, $93^{\circ} \mathrm{C}$.

Total Dissolved Sollids (PPM) : 2500

Estimated Non-Electric Energy Potential (MBtu/h, 30 years): No estimate Type of Overlaying Rock: Sandstone

Estimated Depth to Top of Reservolr (meters): 2000

Flow Rate: 14,583 gpm

Site Land Status:

Total Acres: 640 State, 400 Private

Geothermal Development Status:

Currently being used for flooding of Amaco field

Local and State Attitude Toward Geothermal Development:

The state is occupled with oll, gas, coal, and uranium at the present time. There appears to be no thought given to the use of geothermal

fluid locally.

Land Use and Population:

Midwest: 1000

Edgerton: 400

Comments and Critical Issues:

Resource ownership

County:

Natrona

Adjacent Counties:

Washakie, Johnson, Converse, Albany, Carbon, Fremont

Topography: Relatively level high desert

Historical/Archaeological Significance: Teapot Dome scandal, 10 miles southeast in 1920's

Geological Description:

The surface at Midwest is a rolling, treeless plain, grass covered and primarlly used for ranching. Underlying this is a large basin. The princlple water bearing formation is the Madison Limestone. The. Madison is overlain by the Tensleep formation, a water bearing sandstone. The Madison and Tensleep are deep formations underlying the entire Powder River Basin. The surface of the Madison defines a broad 16,000' deep structural basin. The cavernous formation itself ranges from a few feet to nearly a thousand feet in thickness. 
Subsurface Area of Reservoir: 19,000 square miles (est.)

Present Development Status:

The water being used from the Madison is currently being used for flooding of oil fields. This process brings the oil to the surface, floating it on the water and thus it can be extracted. In some communities in the Powder River Basin, Madison waters are used for domestic purposes.

\section{ENVIRONMENTAL}

Climate:

Prevailling Winds: West, $10 \mathrm{mph}$

Precipitation (annual): Under 10"

Days of Sunshine (annual): Over 330

Biological:

Dominant Flora:

Big Sagebrush

Associates:

Stream Areas:

Blue Grama

Need le and Thread

Plains Prickly Pear

Western Wheat Grass

I solated Ponderosa Pine

Plains Cottonwood Narrowleaf Cottonwood Box Elder Willow

Dominant Fauna:

Mamma Is

\section{Birds}

Western Meadowlark

Antelope

Blacktailed Jack Rabbit

Whitetailed Jack Rabbit

Cottontall Rabbit

Badger

Coyote

13-lined Ground Squirrel

Endangered Specles:

Flora: None inventoried

Fauna: Blackfooted Ferret

Bald Eagle

Peregrine Falcon
Prairie Horned Hawk

Golden Eagle

Raven

Red Tailed Hawk 
TRANSPORTATION AND UTILITIES

Utlilty or Energy Transmission Corridors and Facilities: 8 " gas pipeline entering Midwest from the south; 8" oll pipeline leaving Midwest to the North; 16I KV powerl ine passes North and South to the West of town.

Transportation Corrldors or Facllities: 1-25 North and South; Rt. 387 to Reno Junction.

\section{POPULATION}

General Description of Population: White, 92\%; Mexican, 4\%; Native American, . 4\%; Young Oll Fleld Workers

Economics:

Present Land Use: Housing and Crude OII Production 
Converse County

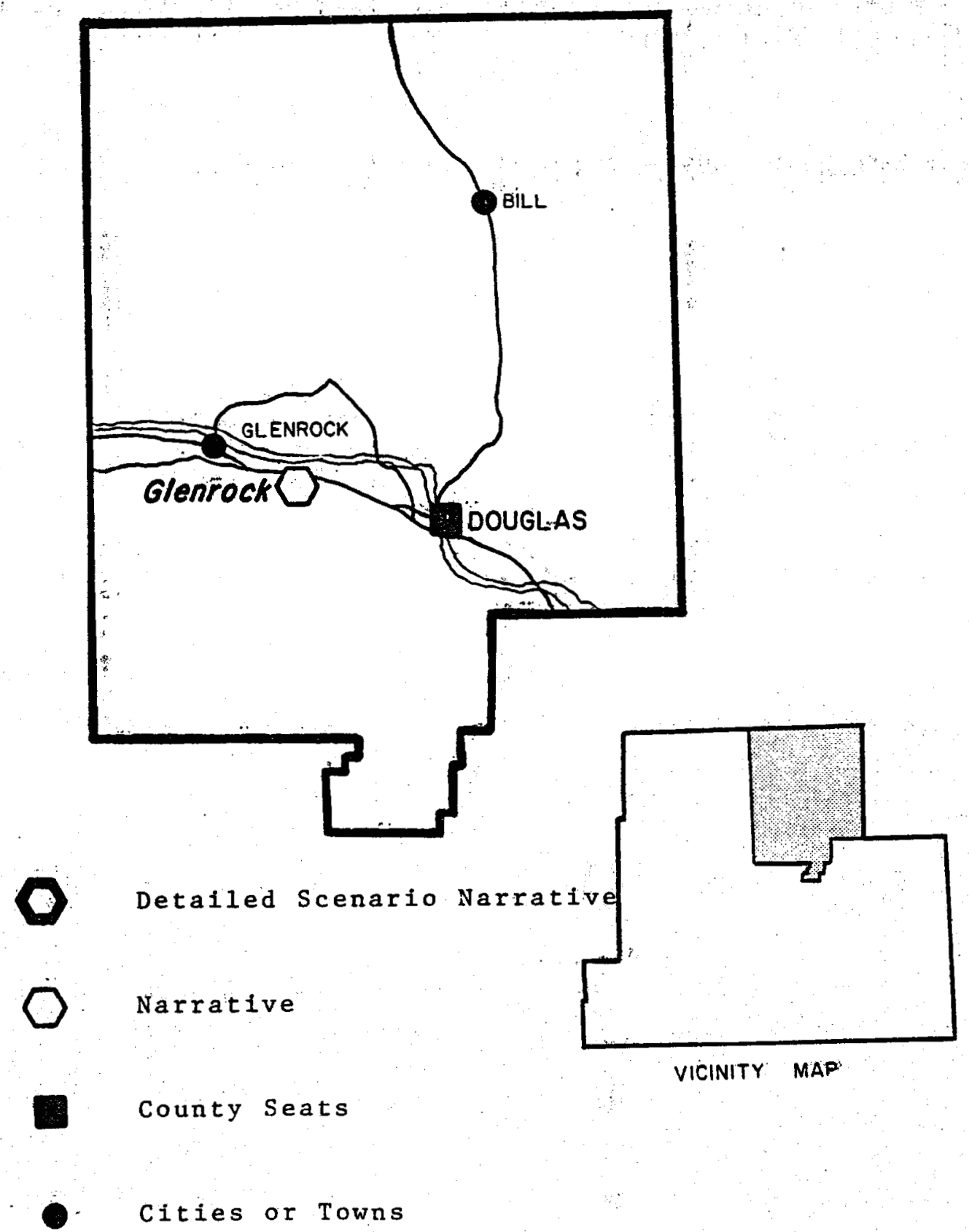


Subchapter IV-3 Glenrock

Glenrock is a town of 1,200 residents about $15 \mathrm{mlles}$ east of Casper in Western Converse county. There are several thermal features in the Glenrock vicinity. The massive amounts of water in the cooling towers of the Dave Johinson Power Plant and the numerous waterflooding projects underway in the oll flelds nearby are just two examples.

Recently the attention of the State Energy Conservation Office was drawn to one particular well in the area. Continental OII Company's \#175 well is located on a large parcel of land which the company leases from the state for oil development. The community of Glenrock, among others, had approached Continental, hoping to use the water produced by the well to heat a community building. The plan was not feaslble from Continental's point of view and would have been far too costly for the town to purchase the necessary pumping equipment and insulated piping. The project was abandoned. Continental continues to recelve suggestions and offers for the potential use of the well. The company, however, has plans for this well that appear to be feaslble and beneficlal to the company's prime intent, oll production.

Several years ago the oll flelds leased by continental found that the cost of using gas as a heating source in their oll recovery processes was becoming a burden. At the time several water production well's were in use in the waterflooding project. The recovery of oil in a flooding project requires several steps. First water is injected into the reservoir that contains the oll which is oftentimes in a homogeneous mixture with water from nearby aquifers. This mixture is referred to as an emulsion where the oll coats the water droplets or a reverse emulsion where the reverse occurs and the water coats the oll droplets. The separation of the water and oll to the surface where it is pumped into large containers. Here the oll is heated and chemically treated to break up the oil and water. It is in this heating stage that natural gas had been used in the past. Continental presently heats the emulsion with the water pumped from hot water production wells and after treatment, adds it to the waterflooding fluid and reinjects it into the formation. This is a simple and very effective use of the resource. Many other flelds that do not have simultaneous occurances of gas and oil are using this system (Personal communication with Joe Galovitch, Continental oll). 
SITE DATA SUMMARY

Glenrock

Physićal Reservolr Data:

Surface Temperature: $84^{\circ} \mathrm{C}$.

Total Dissolved Solids (PPM): 2340

Type of Overlaying Rock: Sandstone (Tensleep)

Estimated Depth to Top of Reservoir (meters): 3048.

Site Land Status:

Total Acres: 9,600

Total Acres Leased (state): 9,600

Geothermal Development Status:

Currently the well is being used for crude oll recovery.

Local and State Attitude Toward Geothermal Development:

The state seemed interested in the development of this area at the time the town of Glenrock was interested.

Land Use and Population:

1700 in the town, nearby Dave Johnson Power Plant, Oil Processing and Open Range. Uranlum mining to the North.

Comments and Critical Issues:

Rights to use the geothermal resource.

SITE LOCATION AND PHYSICAL DESCRIPTION

Latitude:

Longltude:

$42^{\circ} 50^{\prime}$

Rectilinear:

$105^{\circ} 58^{\prime}$

County:

Sec. 20, T33N., R75W.

Converse

Adjacent Counties: Natrona, Johnson, Campbell, Weston, Niobrara, Platte, Albany, Carbon

Topography: Rolling Range about 600 feet alt. and steppe climate Present Land Use: Oil Production, rangeland

\section{GEOLOGICAL/GEOPHYSICAL DESCRIPTION.}

Geological Description: Water originates in Madison aquifer and flows through the Tensleep to the surface. The well being 8000 feet deep, some mixing of Tensleep and Madison waters may occur. 
INSTITUTIONAL CONSIDERATIONS

Institutional

Requil rements

Drilling Permits

Discharge Permits

Geothermal Use Permits
Agency and

Public Attitudes

State Englneer

D.E.Q.

State Land Office

ENVIRONMENTAL FACTORS
Status of Requirements

(1.e., EIA/EIS)

Requil rements

Obtained for oll devel. Obtained for oll devel.

Climate:

Prevallling Winds: West, $10 \mathrm{mph}$

Precipitation (annual): Under 10"

Days of Sunshine (annual): Over 300

Blological:

Dominant Flora:

Big Sagebrush

Assoclates:

Stream Areas:

Blue Grama

Needle and Thread

Plains Prickley Pear

Western Wheat Grass

Plains Cottonwood Narrowleaf Cottonwood Box Elder WIllow

Dominant Fauna:

Mammals

Birds

Antelope

Blacktall Jack Rabblt

Whitetall Jack Rabbit

Cottontall Rabblt

Badger

Coyote

13-I ined Ground Squirrel

Endangered Species:

Flora: None inventorled

Fauna: Blackfooted Ferret

Bald Eagle

Peregrine Falcon

Western Meadowlark

Pralrle Horned Hawk

Golden Eagle

Raven

Red Talled Hawk 
TRANSPORTATION AND UTILITIES

Utility or Energy Transmission Corridors and Facilities: 1-12" gas line going southeast; 1-16" oil pipeline going southeast; $3-115 \mathrm{KV}$ lines going east and west; 1-230 KV I ine going east to west; $1-230 \mathrm{KV}$ IIne going east to southwest.

Transportation Corridors or Facilities: 1.15 miles from 1-80; 16 miles east of Casper on 1-80. 
Subchapter iV-4 Thermal Springs

Site: DOUGLAS WARM SPRING

Location: Sec. 8, T2IN, R7IW:

Quadrangle: Chalk Buttes

Temperature: $30^{\circ} \mathrm{C}$. $\left(86^{\circ} \mathrm{F}\right)$

County: Converse

Ownershlp: Private

Flow: $\quad 800 \mathrm{gpm}$

Description: The Douglas Warm Spring has been known for some time. Historically, it has been used for bathing and irrigation most of this century. Sometime before 1959, the spring was piped to a concrete pool. The current facllities, "Jackalope Plunge", consists of a tank at the spring and a swimming pool to the north (Breckenrldge, 1978, p. 16).

Geology: The spring Issues from the North Platte River alluvium covering the Permian Goose Egg Formation and seems to originate in the upper Opeche Shale, part of the Goose Egg Formation (Breckenridge 1978, p.16).

Socio-Economic: Douglas is a "boom town". which has more than doubled in size since 1970 when there was a population of 2,677 . The Impact from coal and uranlum mining has created the boom. The town is about seven miles north of the spring.

Potential Uses: Greenhouse operations, aquaculture, space heating using heat pumps.

Environment: Typical high plains country with abundant antelope and sagebrush. 
Location: Sec. 25, T30N, R83W.

Quadrangle: Alcova

Temperature: $54^{\circ} \mathrm{C} .\left(129^{\circ} \mathrm{F}.\right)$

County: Natrona

Ownership: U.S. Bureau of Reclamation

Flow: $\quad 100 \mathrm{gpm}$

Description: Alcova Hot Springs were inundated by the bullding of Alcova Dan across the North Platte River and subsequent flooding of Alcova Reservoir by the Bureau of Reclamation in 1938. They are located near the site of the dam about 30 miles SW of Casper (Breckenridge, 1978, p. 45).

Geology: The four springs all issued from the Mississippian-Pennsyivanian Amsden Formation, a limestone with interbedded limey sandstone.. The Tensleep Formation overlays the Amsden and is significantly faulted at the site of the springs (Breckenridge, 1978, p. 45).

Soclo-Economic: The reservoir is used for flood control, hydroelectric power, and recreation. It is the prime water recreation site in summer for Casper.

Potential Uses: No suggested use. There is reason to bellieve that drilling into the Amsden Formation may produce hot water near the edge of the reservoir.

Environment: The area is high desert country with significant cliffs of red chugwater sandstone and dramatic valleys leading to the lake. 
SITE: HORSE CREEK SPRINGS

Location: Sec. 35, T32N, R86W.

Quadrangle: Horse Creek Springs

Temperature: $24^{\circ} \mathrm{C}$. $\left(75^{\circ} \mathrm{F}.\right)$

County: Natrona

Ownership: Private

Flow: $2200 \mathrm{gpm}$

Description: The water from the two maln springs flows down a small bank and collects in a pool. The location is about $16 \mathrm{mll}$ es off the road and about 50 mlles west of Casper (Breckenridge, 1978, p. 47).

Geology: The site is that of complex faulting of Paleozolc and Tertialy rocks as well as the presence of Eocene I gneous Intrusive rocks of the Rattlesnake Mountalns. The intense faulting and complex structure make an assumption of the springs occurrence difficult (Breckenridge, 1978, p. 47).

Soclo-Economic: Desert ranching and open range - $50 \mathrm{mlles}$ to nearest town.

Environment: Desert sage covered hills: 
Site: IMMIGRANT WASHTUB

Location: Sec. 4, T26N, R66W.

Quadrangle: Wheatland $\mathrm{NE}$

Temperature: $21^{\circ} \mathrm{C}$. $\left(70^{\circ} \mathrm{F}.\right)$

County: Platte

Ownership: State of Wyoming

Flow: $\quad 23 \mathrm{gpm}$

Description: Immigrants Washtub was a welcomed stop for pioneers travelling west on the Oregon Trall. The site is two miles SW of the town of Guernsey and is near the Fort Laramie Natlonal Historic Site. There are two springs about 200 feef apart which are principally used for cattle watering holes today (Breckenridge, 1978, p. 52).

Geology: The springs issue from the Hartville Formation and apparently find their source there (Breckenridge, 1978, p. 52).

Socio-Economic: Guernsey is a ranching and rall road community today with a population of about 1000 .

Potential Uses: No use recommended.

Environment: Near the bank of the North Platte River in rolling hills. 


\section{CHAPTER V}

The Green \& Snake River Basins

Region 4

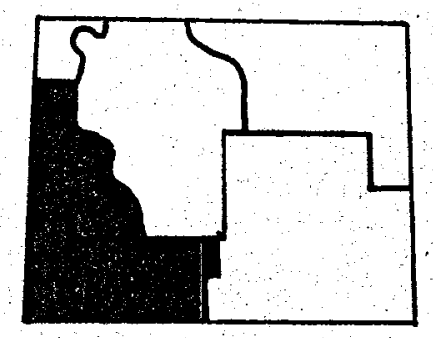

Subchapter

$v-1$

$\mathrm{V}-2$

$\mathrm{v}-3$
Auburn

Site

U.S. FIsh \& Wildilfe Service

Thermal Springs
Proposed Use Treatment

Aquaculture Scenario

Hatchery Discussion

None 
Region 4, The Green and Snake River Basins, occuples the southwestern part of the state. The Great Divide Basin is in the Red Desert in the southern portion while along the western edge of the region, a series of folded mountains known as the Overthrust Belt predominates. The Belt runs from the Uinta Range in Uinta County northward to Teton County and the Grand Tetons. There are five counties in the region whose economic base is ranching, lumber, and a rapidly increasing amount of mineral development, both petroleum and mining. This region has five areas which have been identified as having prospectively valuable geothermal resources, and is characterized by the warmest of Wyoming's thermal springs, outside of Yellowstone National Park.

Region 4 is the smallest region and contains only 13\% of Wyoming's population. It is bordered by three of Wyoming's nelghbor states: Idaho, Utah, and Colorado. The region has five counties: Teton, Sublette, Sweetwater, Uinta and Lincoln. Both Sweetwater and Uinta counties are without evidence of surface thermal activity so the chapter will concentrate on the three northern counties. The Auburn area of Lincoln county offers a real potential for geothermal development. Thelr springs are among the warmest in the state and several commercial applications could be possible: The first section of this chapter will deal with the use of these thermal waters for aquaculture. A short treatment of the trout hatchery operated by the U.S. Fish and Wildife Service will be addressed next and other thermal springs in the region are listed at the end of the chapter.

\section{Subchapter V-I. Auburn}

The Auburn area is one of two areas of Wyoming, outside Yellowstone National Park, which, appears to have potential for electrical power generation from geothermal means. The other area is Huckleberry Hot Springs, which is located between the Yellowstone and Grand Teton National Park, which appears to have potential for electrical power generation from geothermal means. The other area is Huckleberry Hot Springs, which is located between the Yellowstone and Grand Teton National Parks. This spring is in the John D. Rockefeller Jr. Memorial Parkway and it is doubtful that any development other than recreation will be possible. Auburn Hot Springs and Johnson Springs and the associated travertine deposits seem to have the most potential for power generation.

A large fault system runs more than $10 \mathrm{miles}$ north from the springs to the town of Freedom. Along it are found numerous deposits of travertine. This usually indicates that mineral bearing water has been carried to the surface along the fault throughout much of its length.

Auburn Hot Springs are not unusual as they surface, although at $62^{\circ} \mathrm{C}$. $\left(144^{\circ} \mathrm{F}.\right)$ they are the warmest in the state. Nelther is the $37 \mathrm{gpm}$ flow impressive, but two specific occurrences indicate that this area is of special geothermal importance. First is the obvious association with a large fault system that gives evidence of thermal spring activity in the past. Secondly, those who have studied the area's potential, Renner and others (1975), suggest that subsurface temperatures of the Auburn system are up to $150^{\circ} \mathrm{C}$. (Breckenridge, 1979, p. 41). This temperature of $150^{\circ} \mathrm{C}$. is significant because it is the same temperature of the resource being used at Raft River, Idaho. 


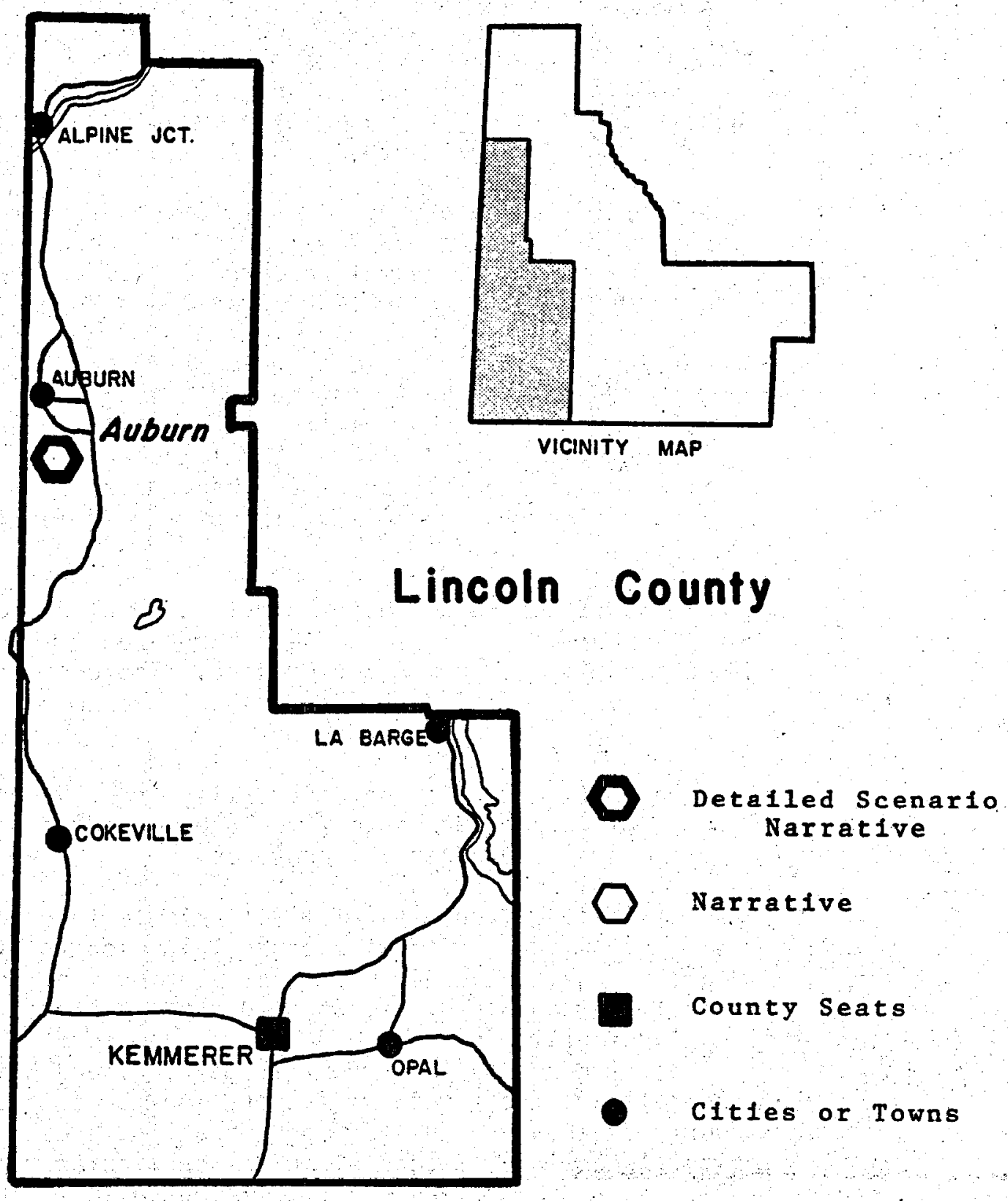


The proposed program at Raft River is to develop the six of seven wells needed for producing and reinjecting $5,000 \mathrm{gpm}$ and to construct a versatile test facility to examine methods of reducing the costs of electricity from approximately $300^{\circ} \mathrm{F}$. sources.

The wells could be drilled with various techniques to enhance flow and/ or reduce costs. The surface faclility would be based on the fundamental isobutane heat transfer cycle using double boilers to extract more heat from the geothermal water. This basic cycle would recelve a long-term test, while various advanced heat exchanger concèpts, methods for reducing heat sink temperature, etc. would be tested on-line by substituting for the conventional components (Kunze, 1977-1978, p. 378).

From such tests, it is hoped that some of the new techniques will result: in reduced power costs. Should a few develop and the reduction costs be possible the $300 \mathrm{~F}$. range of geothermal resource in $50 \mathrm{MW}$ power plant sizes would be competative with coal and nuclear power costs.

Recognizing this real potential for development, several companies have purchased geothermal leases in the immediate vicinity of the springs. There are currently three state geothermal exploration permits, four federal leases and one federal lease application. The lease application is pending the completion of an Environmental Assessment Report before it will be granted. The state exploration permits wlll expire December 1, 1978, unless they are renewed.

There is reasonable assurance that there is electrical generation potential from a geothermal resource in the Auburn area. This potential is subject to the success of the Raft River Project. The development of this potential is several years off in the future therefore an alternate direct heat use is proposed.

A few miles west of Auburn is the Star Valley Trout Ranch. The operation is located in idaho but a similar project could be operated in Auburn using geothermally controlled water temperatures.

The process of raising trout is relatively simple in concept yet there are three important and critical factors which control the success of such a project. First, the quality of the water must be considered. Secondly the identification and diagnosis of disease and other harmful elements that may present themselves must be prepared for. Thirdly, the temperature of the water for optimum growth, spawning, and hatching must be carefully controlled. The first two factors mentioned here are of significant importance to any trout farming operation. The extent to which they are important is entirely dependent on the particular site for the hatchery, its source water, and the size of the operation. This discussion will address the advantage of using geothermal heat to control temperature and stimulate production.

The geothermal fluid would be run through one side of a heat exchanger, while the fresh water was run through the other side. The rates of flow through the heat exchanger could be controlled by a thermostat. A series of these systems could be set up one for each of the various temperatures required in the process. 
In this way the potentlally harmful constitution of the geothermal water would not be mixed with the pristine water, preserving its quality.

The Call fornla Hot Creek Hatchery uses $17^{\circ} \mathrm{C},\left(62^{\circ} \mathrm{F}\right.$ ) water from a hot creek which is diverted and mixed with cooler water. They have found that by the careful control of water temperature their fish mature $1 / 3$ faster than others. They have also found that $17^{\circ} \mathrm{C}$. $\left(62^{\circ} \mathrm{F}.\right)$ is opt imum temperature for maximum growth whlle the best spawning temperatures are from $11^{\circ} \mathrm{C}$. $\left(52^{\circ} \mathrm{F}.\right)$ to $12^{\circ} \mathrm{C}$. $\left(54^{\circ} \mathrm{F}\right.$ ) (Personal Communication, BIII Johnson, $9 / 78$ ).

The intent of introducing heat to the hatchery is to reduce the time It takes from egg to maturlty. Table $v-1$ Indicates that to a polnt, the warmer the water, the faster the egg wlll develop and hatch.

\section{TABLE $V-1$}

$\begin{array}{lrl}4{ }^{\circ} \mathrm{C} . & 39^{\circ} \mathrm{F} . & 20 \text { days } \\ 5^{\circ} \mathrm{C} . & 41^{\circ} \mathrm{F} . & 17 \text { days } \\ 6^{\circ} \mathrm{C} . & 43^{\circ} \mathrm{F} . & 15 \text { days } \\ 8^{\circ} \mathrm{C} . & 46.5^{\circ} \mathrm{F} . & 12 \text { days }\end{array}$

The typlcal western trout, such as ralnbow trout, are spring spawners. But other species such as the Missourl Straln Ralnbow spawn in the fall of the year. The combination of both spring and fall spawners can greatly. Increase the efficiency of the hatchery consequently increasing the annual harvest.

Therefore, relatively simple modification of a current hatchery and low temperature resources could greatly enhance the harvest of a commerclal fishery such as a trout farm. 
GEOTHERMAL ENERGY EVALUATION

NON-ELECTRIC GEOTHERMAL ENERGY APPLICATIONS

SITE: Auburn Hot Springs Area

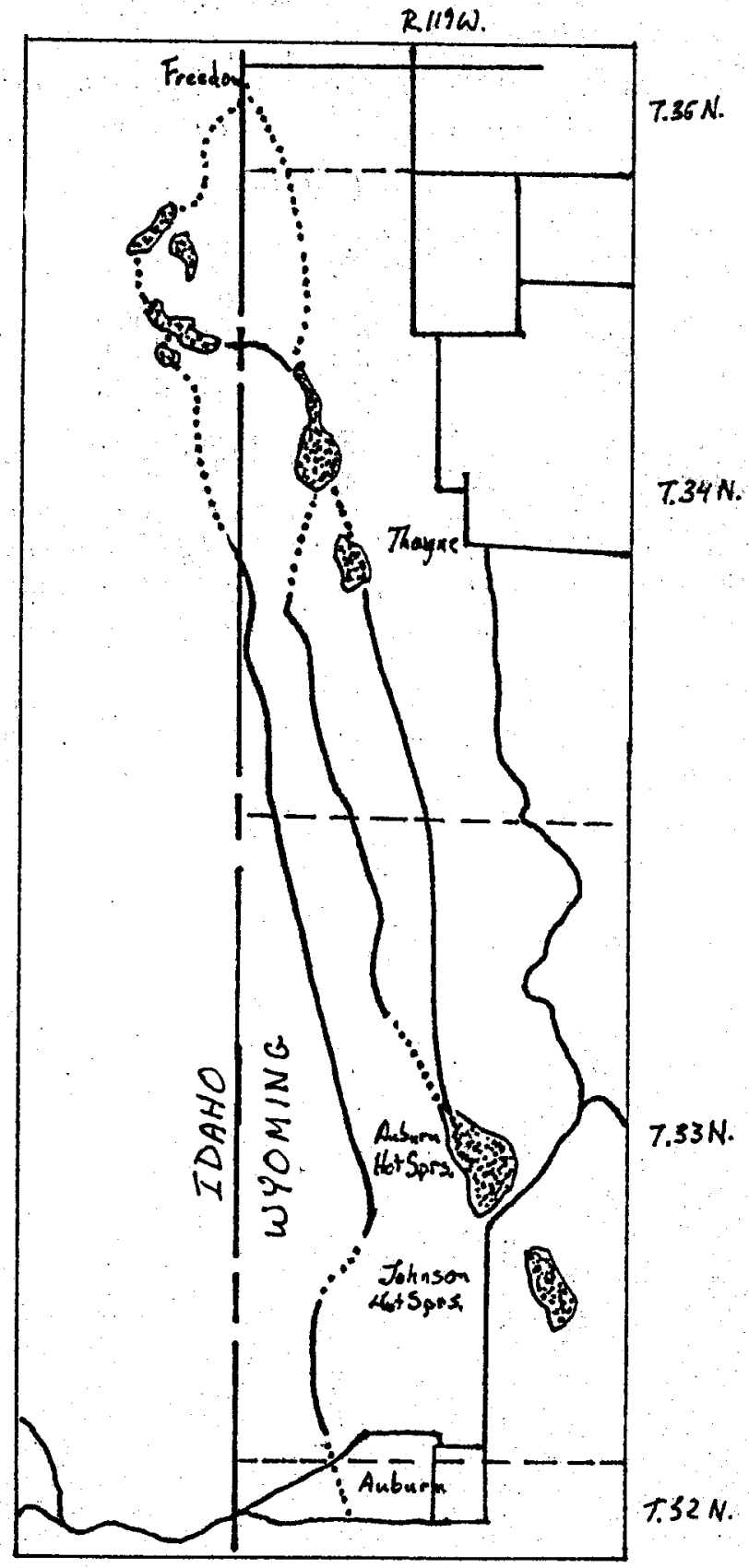

Travertine Deposites

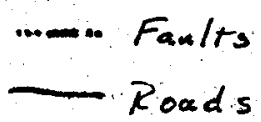

(Taken from Breckenridge, 1978 
SITE DATA SUMMARY

SITE: AUBURN HOT SPRINGS

Physical Reseryolr Data:

Surface Temperature: $62^{\circ} \mathrm{C}$. (144 $\left.{ }^{\circ} \mathrm{F}.\right)$

Total Dissolved Sollds (PPM) : 5250

Type of Overlayling Rock: Antarch Shale over Dinwoody Formation Dolomitic siltstone

Estimated Depth to Top of Reservolr (meters): Unknown

Site Land Status:

Total Acres: 7000 private

Total Acres Permitted: 1149.6 state

Geothermal Development Status:

Auburn has small private swimming pool.

Local and State Attitude Toward Geothermal Development:

Local attitude shows little or no interest. State has $11+t$ le interest. Land Use and Population:

Rural, treeless, grazing land

Comments and Critical Issues:

Potential problems with surface owners of State Permitted Lands.

SITE LOCATION AND PHYSICAL DESCRIPTION

Latitude: $\quad 42^{\circ} 50^{\prime} \mathrm{N}$.

Longtitude: $\quad 1110 \mathrm{~W}$.

Rectillnear: Sec. 23 and 26, T33N, RI I9W.

Present Land Use: Grazing and one private pool

Future Land Use Plans: Projected aquaculture and potential power generation. Historical/Archaoological

Significance: One spring was used to mine sulphur.

\section{GEOLOGICAL/GEOPHYSICAL DESCRIPTION}

\section{Geological Description:}

The Springs occur along the north-south trending Hemmert anticline and surface in the lower Triassic Dinwoody Formation. There appears to be three deep-seated faults trending north-sough through the area: The Hemmert fault, the Freedom fault, and the Auburn fault. Surface travertine deposits along the faults leave little doubt that they have conducted mineral rich waters to the surface. 
Geophysical Summary:

According to geochemical work by Renner and others (1975) subsurface temperatures of the Auburn system are up to $150^{\circ} \mathrm{C}$, making it one of the two areas of the state, outside Yellowstone, which even approach electrical generation potentlal.

\section{RESERVOIR CHARACTERISTICS}

Reservoir Temperature:

Surface: $62^{\circ} \mathrm{C} .\left(143.6^{\circ} \mathrm{F}.\right)$

Subsurface: $150^{\circ} \mathrm{C} .\left(\mathrm{S}^{\circ} \mathrm{O}_{2}\right)$

Flow Rates: $37 \mathrm{gpm}$

$\mathrm{pH}: 7.5$

Total Dissolved Solids: 5250

Fluid Chemistry:

$\begin{array}{lrllll}\mathrm{Ca} & 1100 & \mathrm{ppm} & \mathrm{F} & 0.6 & \mathrm{ppm} \\ \mathrm{Mg} & 70 & " & \mathrm{~S} & .8 & " \\ \mathrm{Na} & 1400 & " & \mathrm{StO}_{2} & 35 & n \\ \mathrm{~K} & 140 & " & \mathrm{~B} & 2.15 & " \\ \mathrm{CO}_{3} & 0 & " & \mathrm{Hard} & 1300 & \\ \mathrm{HCO}_{3} & 860 & " & & & \\ \mathrm{SO}_{4} & 1100 & " & & & \\ \mathrm{Cl} & 1700 & " & & & \\ \mathrm{NO}_{5} & 0 & " & & & \end{array}$

(Breckenridge, 1978, p. 41).

LAND OWNERSHIP, LEASING AND PERMITTIING

State of Wyoming:

2 year Exploration Permits:

0-36026* Sec 13, T. 33 N., R. 119 W. 120 acres

E $\frac{1}{2} N E \frac{1}{4}, N E \frac{1}{4}$ SE $\frac{1}{4}$.

$0-36027^{*} \quad \operatorname{Sec} 16$, T. 34 N., R. 119 W. $\quad 389.6$ acres Lots $1-4, E \frac{1}{2}$.

$0-36028^{*} \quad \operatorname{Sec} 36$, T. 34 N., R. 119 W. 640 acres All.

Permitted to: Intercontinental Energy Corporation 7503 Marin Drive

Suite 1-C

Englewood, Colorado 80110

* Due to expire on December 1 , 1978. 
There have been no state leases to this point.

U.S. Bureau of Land Management:

Leases:

1) $W-44532$

Sec. 2, T. 33 N., R. 119 W.

All but Lot 1 .

Sec, 3, T. 33 N., R. 119 W.

Lot $1-4, S \frac{1}{2} N \frac{1}{2}, S \frac{1}{2}$.

Sec. 4, T. 33 N., R. 119:W.

Lots $1-6, S E \frac{1}{4}, S \frac{1}{2} N E \frac{1}{4}$.

Sec. 9, T. 33 N., R. 119 W.

Lots $1-4, E \frac{1}{2}$.

Sec. 16, T. 33 N., R. 119 W.

Lots $1-4, E \frac{1}{2}$.

Leased to: U.S. Geothermal

39 Broadway

Sulte 3100

New York, NY 10006

2) $W-44533$

Sec. 10, T. 33 N., R. 119 W.

All:

Sec. 11, T. 33 N., R. 119 W.

AlI:

Sec. 14, T. 33 N., R. 119 W. $N \frac{1}{2} N W \frac{1}{4}, S E \frac{1}{4} N W \frac{1}{4}, N E \frac{1}{4}, E \frac{1}{2} S E \frac{1}{4}$.

Sec. 15, T. 33 N., R. 119 W.

All:

Leased to: U.S. Geotherma I

39 Broadway

Suite 3100

New York, NY 10006

3) $W-47940$

Sec. $33, T .34$ N., R. 119 W.

Lots $1-6, N E \frac{1}{4}, N \frac{1}{2} S E \frac{1}{4}$.

Sec. 34, T. 34 N., R. 119 W.

Lots 1-7, S $\frac{1}{2} N W \frac{1}{4}, S W \frac{1}{4}, S W \frac{1}{4} N E \frac{1}{4}, W \frac{1}{2} S E \frac{1}{4}$.

Sec. 35, T. 34 N., R. 119 W.

Lots $1-3,8,9$, NE $\frac{1}{4} S W \frac{1}{4}$.

Leased to: Thermex Company

1600 Broadway, Suite 1560

Denver, CO 80202 
4) $W-47741$
Sec. 15, T. 34 N., R. 119 W. $S W \frac{1}{4} S W \frac{1}{4}$.

Sec. $21, T .34$ N., R. 119 W. Lots $1-6, S \frac{1}{2} N E \frac{1}{4}, S E \frac{1}{4}$.

Sec. 22, T. 34 N., R. 119 W. Lots 3-5.

Sec. $27, T .34$ N., R. $119 \mathrm{~W}$. Lots $2-4, W \frac{1}{2} E \frac{1}{2}, W \frac{1}{2}$.

Sec. $28, T .34$ N., R. 119 W. Lots $1-4, E \frac{1}{2}$.

Leased to: Thermex Company 1600 Broadway Suite 1560

Denver, CO 80202

Lease Applications:

Sec. $21, T .33$ N., R. $119 \mathrm{~W}$. Lots $1,2,2, N E \frac{1}{4}, N E \frac{1}{4} S E \frac{1}{4}$.

Sec. 22, T. 33 N., R. 119 W. $N W \frac{1}{4} S W \frac{1}{4}$.

$\begin{aligned} \text { Applicant: } & \text { Thermex Company } \\ & 1600 \text { Braodway } \\ & \text { Suite } 1560 \\ & \text { Denver, CO } 80202\end{aligned}$ 
GEOTHERMAL DEVELOPMENT STATUS

Present Development Status: One private swimming pool.

Projected or Planned Development: Aquaculture; power production, similar to the Raft River, Idaho, project.

INSTITUTIONAL CONSIDERATIONS

Institutional

Requi rements

\section{Building Codes \\ Zoning \\ Water Rights \\ Geothermal Use}

Federal Lands
Agency and

Public Attitudes

County Engineering

County Planning

State Engineer

State Land Office

Permits

Leases

BLM

Leases

Lease Applications
Status of Requirements

(i.e., EIA/EIS

Requirements)
Currently writing an

EAR for $W-49770$

ENVIRONMENTAL FACTORS

Climate: Prevailing Winds, Westerly

Precipitation (annual), Less than 10"

Days of Sunshine (annual), More than 250

Biological:

Dominant Flora:

Foothills

Stream Areas

Mountain Mahogany

Big Sagebrush

Narrow Leaf Cottonwood

Willow

Dogwood

Rose

Dominant Fauna:

Mammals

Elk

Moose

Muledeer

Red Squirrel

Porcupine

Black Bear

Cottontail

Whitetai led Jackrabbit

13-lined Ground Squirrel
Birds

Golden Eagle

Raven

Red Tai led Hawk

Stream Areas

Mall lard Ducks

Canadian Geese

Greater Sand Hill Cranes 
Endangered Species:

Flora: None inventoried

Fauna: Grizzley Bear (threatened)

Grey Wolf.

Peregrine Falcon

Bald Eagle

Whooping Crane

TRANSPORTATION AND UTILITIES

Transportation Corridors or Facilities: Route 89 is 5 miles east of Auburn Hot Springs.

\section{POPULATION}

General Description of Population: 100\% Anglo ranching community Economics: Present Land Use, ranching and grazing, some dairy. Future Land Use, Aquacultare and power generation potentials. 


\section{Teton County}
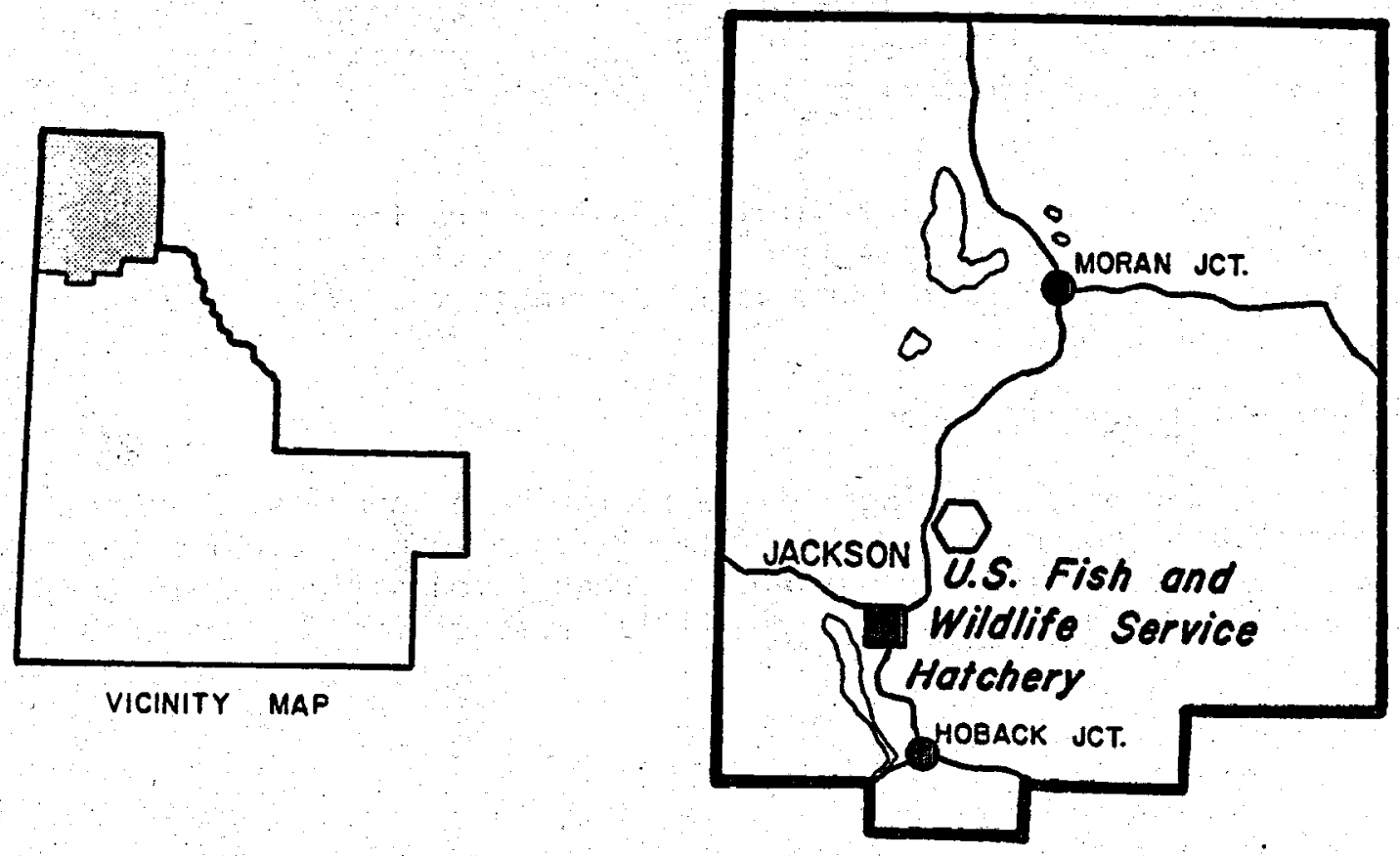
0
Detalled Scenario Narrative
0
Narrative
-
County Seats
- Cities or Towns 
Subchapter V-2 U.S. Fish and Wildlife Service Hatchery

Just north of Jackson in Teton County is the National Elk Refuge. This protected area, in the sheltered valley of the Snake River, is operated by the United States Fish and Wildlife Service which operates a fish hatchery on the refuge.

The hatchery grows fish for stocking the various streams and lakes of the National Parks and Forests of the area. A unique system is employed to heat the water to the proper temperature. Water from a thermal spring is pumped about $1 / 4$ mile to the hatchery where one system of pipes is used for the geothermal water and another for the fresh well water. Both the fresh and hot water is piped to each of the hatchery's runs (approximately 40) where each pipe has a valve. The temperature is regulated manually for the amount of hot and cold water introduced. The temperature is checked by a hand held thermometer. The mixed water is then piped to the outdoor tanks where the fish mature. Some concern was expressed at the time of the sitervisit in October of 1978 that an excessive amount of nitrogen was being intorduced from the spring water and killing fish on occasien.

There is no simple retrofit solution to this problem but the use of heat exchangers to transfer heat from the spring to fresh well water could only help the overall operation and would eliminate the excess nitrogen which çauses fish killis. ?.

Subchapter V-3 Thermal Springs

The remainder of the springs in the region have been listed in the following table. Some of them exhibit significant potential which may be developed. Several of the springs lie in Grand Teton National Park and, although showing good potential, have little prospect for development. 
TABLE $V-2$

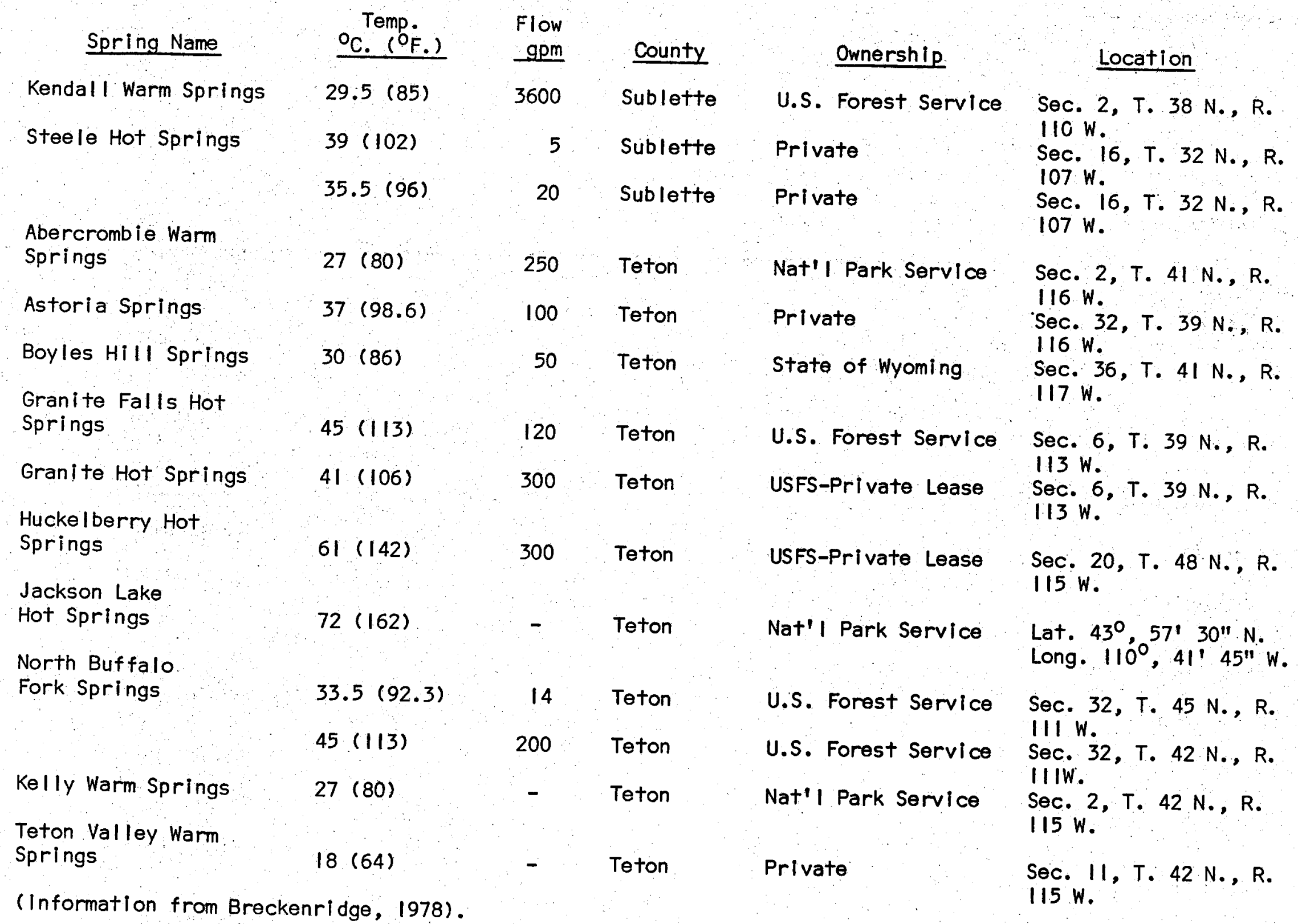


CHAPTER VI

The Yellowstone River Basin

Region 5
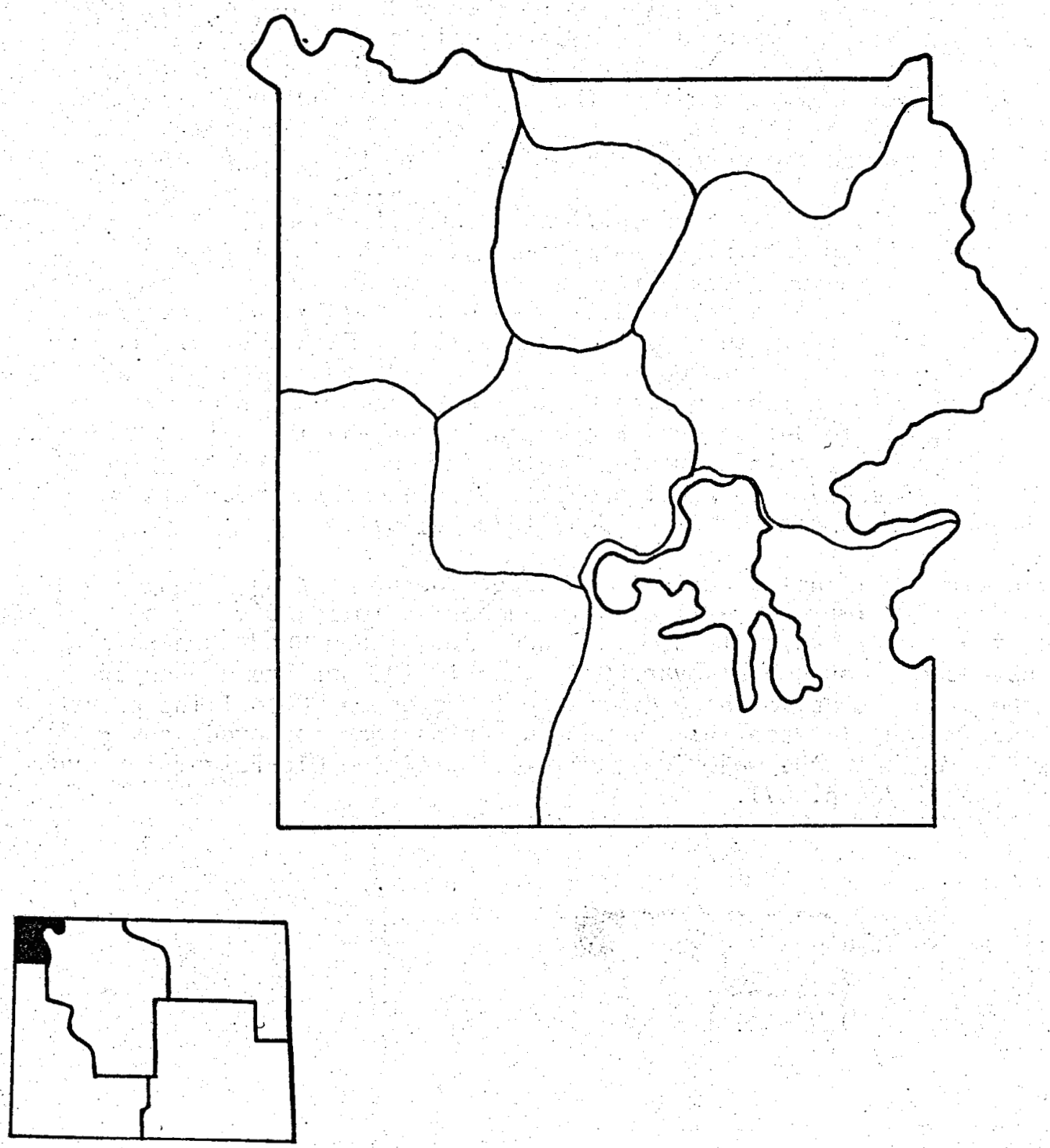
Subchapter VI-1 Yellowstone

More than a half million years ago, the third in a series of explosive volcanic eruptions in the Yellowstone area showered tremendous amounts of volcanic ash and pumice across the western United States. Nearly as abruptly as the eruption itself, a great caldera was formed in the central part of Yellowstone. The great subsided pit, 30 miles across and 45 miles long, was several thousand feet deep. Lava flowed from the faults around the circumference of the caldera and began to fill it. Once covered almost entirely by mountains, the part that collapsed, nearly one-third of the total Park area, is now characterized by low rolling plateaus formed from the thick lava flows (Keefer, 1976).

Heat from the enormous reservoir of molten rock which produced the massive eruption still remains deep beneath Yellowstone. The formation of the caldera and the subsequent eruptions and lava flows contributed to the shape of the present day landscape. Three glacial periods and a constant weathering process, particularly notable in the Grand Canyon of the Yellowstone, completed the current land forms of Yellowstone (Keefer, 1976).

Since the Lewis and Clark expedition of 1803, the upper Yellowstone slowly became familiar country to explorers and trappers Increasingly credible storles appeared through succeeding years, leading the government to organize several exploratory expeditions in the $1870^{\prime} \mathrm{s}$. It was primarily as a result of these early surveys that the National Park was established. Early scientific work was devoted to describing and classifying the thermal and geologic features of the Park. The attempt has been made in more recent studies to define subsurface conditions and mechanisms using a wide variety of geochemical, geophysical and remote sensing techniques. Yellowstone is probably the most thoroughly studied non-commercial geothermal area in the world (Breckenridge, 1978, p. 67).

Yellowstone National Park includes about 100 hot spring "groups" with individual thermal features estimated to number up to 10,000. Total flow from the entire system is about $49,000 \mathrm{gpm}$. Three hundred eighteen springs have been measured at over $90^{\circ} \mathrm{C}$. Nearly 100 springs are superheated, the water is up to three degrees Cels ius above the boiling point. Surface expression of these thermal waters varies from isolated, superheated steam vents to the major geyser activity of the Old Faithful Area (Breckenridge, 1978, p. 67). 
Figure VI-1.

Yellowstone Therma1 System

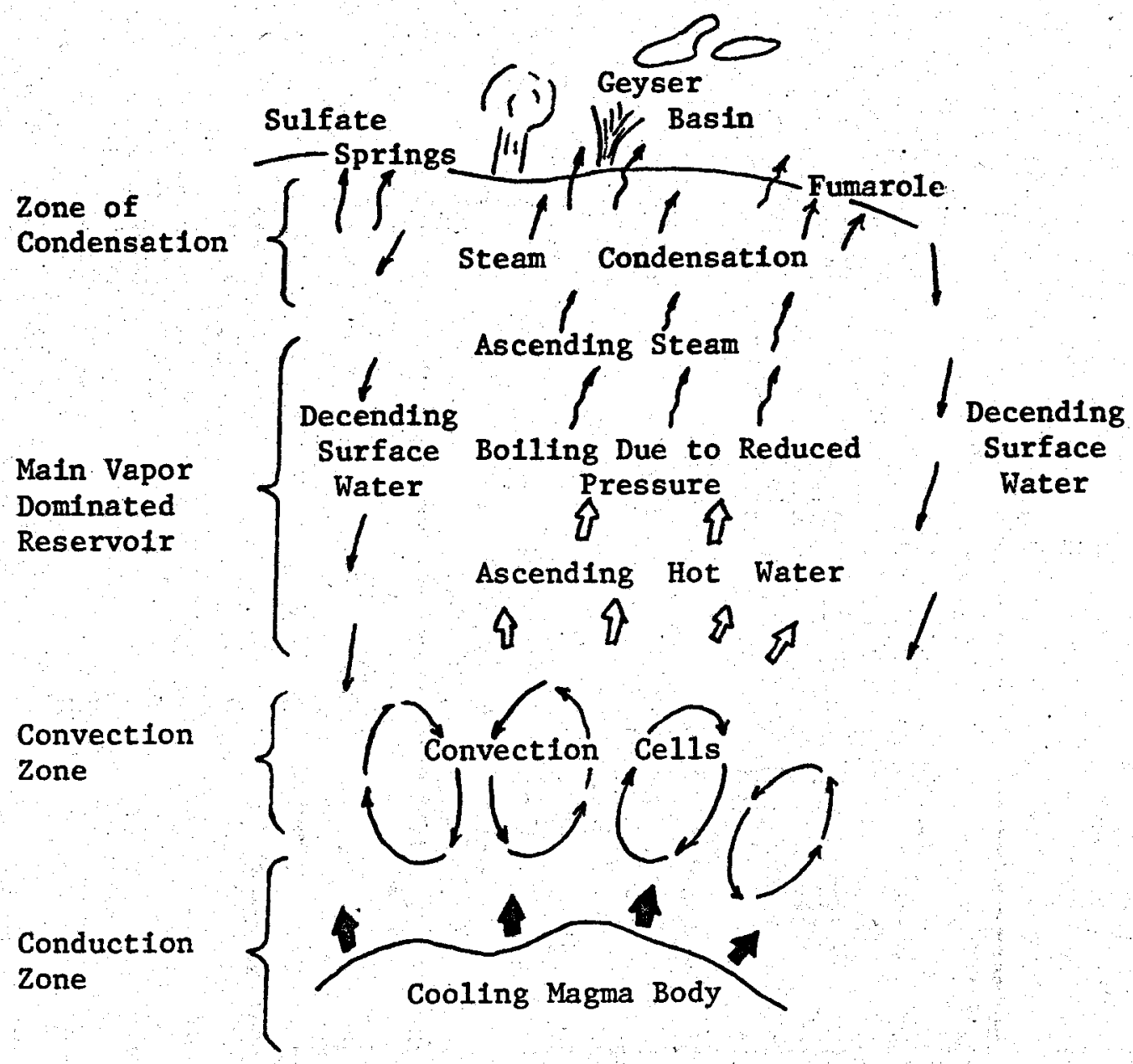

Taken from Breckenridge, R.M. and Hinckley, B. S., 1978 .

Thermal Springs of Wyoming, Bulletin 60 .

The Geological Survey of Wyoming, Laramie, Wyoming. 
FIGURE VI-1

\section{Yellowstone National Park}

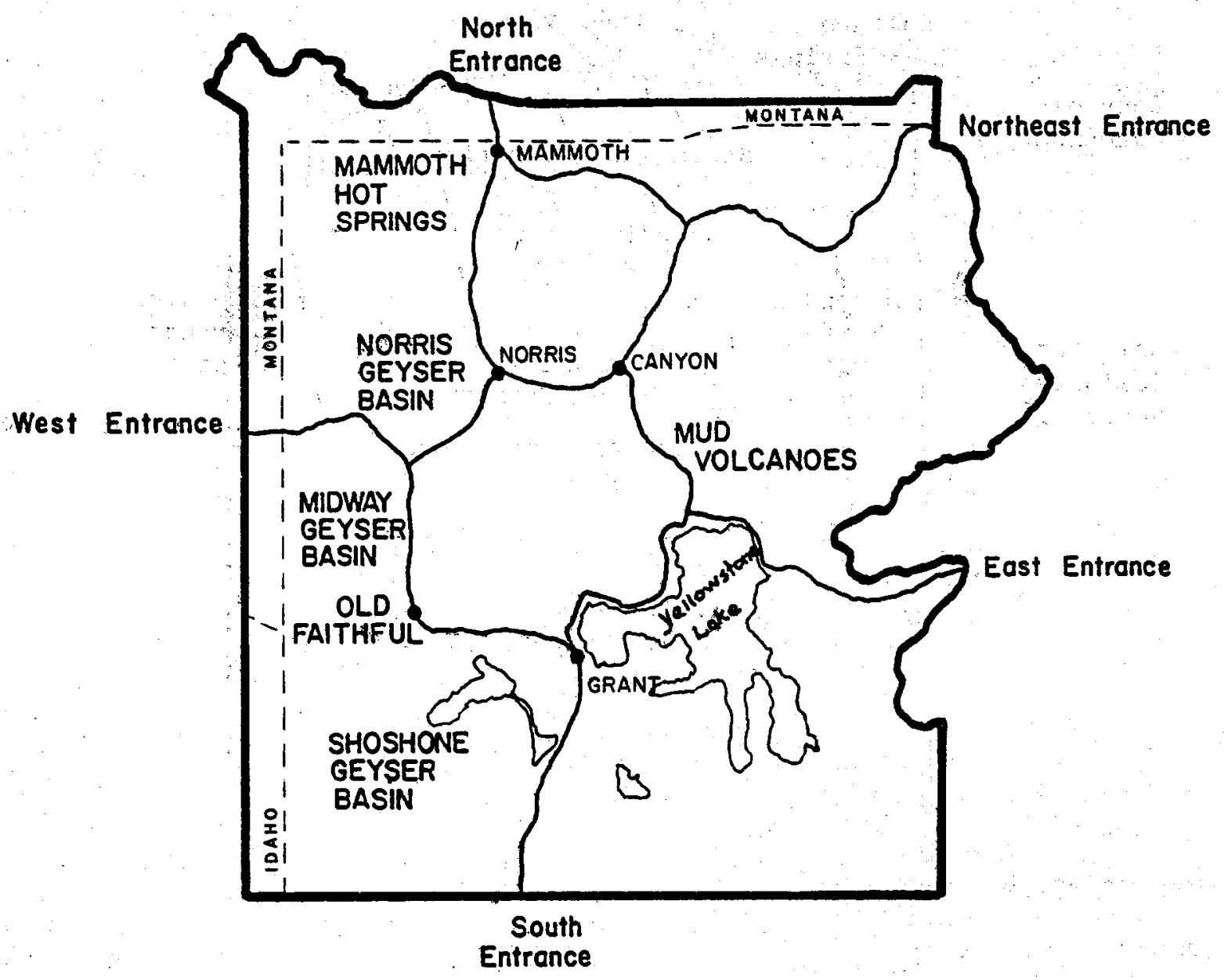


THERMAL FEATURES

Yellowstone has several significant thermal features, each of which are surface manifestations of the Yellowstone Thermal System (Figure VI-1). The several geyser basins comprise the largest volume of thermal activity in the Park.

The Upper Geyser Basin surpassing both in numbers of thermal manifestations and in volume of discharges water, and similar area in the world. The springs are deep and clear with near bolling water. Such names as Emerald Pool, Morning Glory Pool, and Sapphire Pool indl cate their colorful nature. Geysers in the basin such as Castle, Glant, Riverside, and Old Falthful, are indicative of the nonstop eruptive activity of the Upper Geyser Basin.

Midway Geyser Basin is downstream on the Firehole River from the Upper Geyser Basin. It contains 30 significant springs and the Park's largest hot pool, the 370 feet diameter Prismatic Lake.

Downstream, the Lower Geyser Basins cover nearly 15 square miles, with numerous springs, geysers, and fountain paint pots. 
Shoshone, Heart Lake, and West Thumb Geyser. Basins are smaller but still active, each with numberous springs and geysers.

Mammoth Hot Springs in the northern portion of the Park is the largest travertine spring area of Yellowstone. Massive travertine cliffs and pools, streamers of multi-colored algae and cascading sheets of $70^{\circ} \mathrm{C}$. water make Mammoth one of the most spectacular areas in the Park.

The mud Volcano area on the westside of the Yellowstone River is a large sulfate tract. Although the waters are only $68^{\circ} \mathrm{C}$. the abundant gases produce a boiling appearance in the sediment-filled waters.

Norris Geyser Basin is an example of sub-surface mixing of sulfate and alkaline waters. Covering about one square mi le, Norris is an assortment of clear, deep springs, geysers, sandy gaseous tracts, muddy springs, mudpots, vast sinter deposits and loose, caky sulfur areas. Thirty-five geysers were active in the Basin in 1926. The most spectacular feature in Norris Basin is Steamboat Geyser, the world's highest geyser. During 1978, it has erupted twice, once in March and then again in August, reaching a height of over 400 feet.

\section{INSTITUTIONAL FACTORS}

It is easy to understand that the United States' premier natural area, Yellowstone National Park will have attached to it various controls and regulations regarding its use and development. The following is a section from the Yellowstone National Park Master Plan. It delineates some of the legislation which may effect any commercial interest in Yellowstone. It also sets the tone for this first National Park and precludes geothermal development in the foreseeable future.

"Development shall be excluded from thermal areas: however, walking path access and small selif-guiding interpretive devices may be permitted. As new thermal features appear, they shall be allowed to develop without interference from man, unless they concern the safety of the public." (Yellowstone National Park Master Plan, 1973).

Yell lowstone National Park by it's establishment act of March 1, 1872, (17 Stat. 32), was "dedicated and set apart as a public park or pleasuringground for the benefit and enjoyment of the people" and "for the preservation, from injury or spoilation, of all timber, mineral deposits, natural curiosities, or wonders... and their retention in their natural condition."

The act of March 1, 1872, which established Yellowstone National Park, reaffirmed this principle and laid down criteria for selection of such lands to be set aside, thus establishing the basic framework for the unique land-use policy embodied within the present National Park System. 


\section{CHAPTER VII}

\section{INSTITUTIONAL CONSIDERATIONS}

There are many institutions whose role is that of management, regulation or control of some aspects of the development process. The attempt will not be made here to identify those aspects of the institutional matrix which are positive or negative but rather a discussion of roles will be presented.

\section{FEDERAL}

Wyoming's largest land owner is the United States Government with 48. $1 \%$ of the surface ownership and $72 \%$ of the mineral ownership (Wyoming: A Land Use Inventory 1973, p. I). Various agencies of the federal government have input into the geothermal activities in Wyoming. These agencies are the U.S. Forest Servlce, (USFS); U.S. Bureau of Land Management, (BLM); U.S. Bureau of Reclamation, (USBR); U.S. Envi ronmental Protection Agency, (EPA); U.S. Bureau of Indian Affalrs, (BIA); the U.S. Fish and Wildilfe Service, (FWS); and the U.S. Geological Survey, (USGS). The roles and responsibilities of each of these agencies are generally addressed below. It must be remembered that there are major responsibilities common to all federal agencies when considering action of federal lands or properties. The most important of these is the National Environmental Policy Act of 1969 (NEPA), which provides that an Environmental Impact Statement must be filed on any major federal action which might affect the quality of the human envil ronment. In dealing with NEPA, agencles usually work together in preparing a document but there is most often a designated lead Agency which coordinates the effort. All of these agencles have a variety of planning programs designed to make maximum use of the resources at hand. Some of the systems are rather complex, while others are a simple set of districts with direct-line authority.

\section{United States Forest Service (USFS)}

As a multiple use agency, the U.S.F.S. regulates and administers surface resources such as recreation, forage, timber, wildilfe, and fisheries. Mineral resources are generally regulated by BLM and/or USGS (McClain, 9/78, Personal Communication).

\section{United States Bureau of Land Management BLM}

Basically, the BLM is the management agency for public lands that are not designated for management by other agencies. The Mineral Leasing Act of 1920 gives the BLM the responsibility to determine if the federally-owned lands with minerals shall be leased and, if so, under what terms and conditions. The BLM recelves and processes permit and lease applications on all federal lands and takes action leading to the issuance or rejection of these applications (McClain, 9/78, Personal Communication).

\section{United States Bureau of Reclamation (USBR)}

This agency supervises the development of reclaimed lands, principally 
reservoirs and irrigation projects. Generally it interfaces with BLM when alternate uses are recommended.

United States Environmental Protection Agency (EPA)

This agency is a regulatory body whose main concern is maintaining a given quality of environment for air and water. It oversees and monitors proposed changes and regulates standards of development.

United States Fish and Wildlife Service (FWS)

Wildlife refuges fall under the administration of this agency as will as the administration of the Endangered Species Act of 1973. The FWS interacts with multiple use agencies in the case of any action beyond their preview in their managed area.

United States Geological Survey (USGS)

The discovery, development, and production of geothermal resources from Federal lands is supervised by the Conservation Division of the USGS. The responsibilities include enforcing leases after they have been granted by, BLM and the conservation of the natural resource.

United States Bureau of Indian Affairs (B|A)

The Wind River Indian Reservation operates as a unique entity and has its own Joint Tribal Council. There are public, private, and Indian lands on the Reservation and a variety of permits are available for special uses.

STATE

Initially it must be stated that there are a variety of laws in Wyoming which concern the leasing, exploration, and use of minerals. Likewise, a number of statutes are in existence regarding the use of surface and ground water. The relatively recent interest in geothermal use in Wyoming leaves the exploration and development of resources in an unclear position. Significant steps have been taken by the State Geologist and the Commissioner of Public Lands in developing an exploration permit system for geothermal as well as a leasing system for state lands.

The system by which an interested party first applies for an Exploration Permit. This permit costs $\$ 15$ for the application and $\$ 1 /$ acrel year for the permit if granted. The permit allows the holder to explore for geothermal energy for three years, reporting the exploration activity and findings to the state. At the end of the three year term the holder can request an extension or apply for a lease or let the permit expire. The lease is for an initial 10 year period at a fee of $\$ 2 / a c r e / y e a r$. After geothermal resources are developed, the state requires royalties: a) Ten percent $(10 \%)$ of the gross revenue as determined by the Board, made or incurred with respect to transmission or other services or processes, received from the sale of steam, brines, from which no minerals have been extracted, and associated gases at the point of delivery to the purchaser thereof. b) A royalty of five percent (5\%) of the gross revenue, exclusive of charges, approved by the Board, that were made or incurred with respect to transmission or other services or processes, received from the sale of mineral products or chemical compounds recovered 
from geothermal fluids or chemical compounds (Rules and Regulations, (1975).

The major issue yet to be resolved is the legal nature of geothermal energy as a natural resource. Is it groundwater, a mineral or a unique entity? At this point in time it appears that the state is looking at it as a unique entity. There are advantages to this but it could create the necessity of Legislation for the amendment of existing laws to include geothermal. A case in point, the Department of Environmental Quality, Water Quality, and Solid Waste Management. In effect, it appears that a geothermal development would need to obtain permits from Land Quality and perhaps Air Quality unless the DEQ can develop a special geothermal permitting system for geothermal use.

Various agencles may be drawn into the regulation of geothermal development. Currently, the lack of specific legislation and a designated agency to overview potential development activity may cause confusion in the regulatory process. It seems appropriate that the State Engineer, whose current responsibllity covers all groundwater, would be the appropriate agency to intergrate regulatory efforts. These efforts should be made in close coordination with the State Land office.

The need for clarifying leglslation will become more and more apparent as the resource potential is better understood throughout the state. Future legislation may direct regulatory responsibility elsewhere as the current designation is unclear and potentially inadequate.

Other agencles that may be involved in geothermal development and or legislation are: The Department of Economlc Planning and Development, The Energy Conservation Office, State Engineer, State Department of Game and Fish, State Geological Survey, Industrial Siting Council, State Land Office, Oil and Gas Commission, Public Service Commission, Recreation Commission, Department of Revenue and Taxation, and the University of Wyoming resear.ch centers. 
CHAPTER VII

SUMMARY

This report has presented an overview of geothermal energy and its current and potential uses in Wyoming. Within the five regions there are unquestionably uses and users which have not been discussed. The intent has been to evaluate the exlsting uses and project some real possibilities of future utilization. Each of the regions of Wyoming have potentials for geothermal development. Chapter I, is devoted to a general overview of Wyoming and some of the issues of this report. Chapters 11 through V are concluded with a summary of thermal springs in the region. Chapter VI is a discussion of the uniqueness of Yellowstone from both an institutional point of view and a natural one. Chapter VII discusses the institutional situation at a federal and state level as it applles to geothermal development in Wyoming.

The development of a barley malting plant In Blg Horn County is the initial discussion in Chapter 11 . There the potentials for development of a plant at Little Sheep Mountain Springs on the shore of the Big Horn River are discussed. The spring seems to offer some promise yet no geophysical or detailed geological studies have been done.

Further south in the region, an existing geothermal use has been examined and suggestions made to improve the facility. The first oil well in Wyoming is located south of Lander on the Countryman Ranch and is issuing not oil but water. The artesian flow is being used to heat a greenhouse at the site. The use of storage tanks is suggested to al leviate much of the slit problems of the well and suggestlons have been made for heating several buildings on or near the ranch.

The third subchapter of Region 1 is the Hot Springs at Thermopolis. These have only been given a general outline and an Indication of the significant heating potential which might be gained from these resources. For some of the resources, such as those in Hot Springs State Park, no suggestion for development is made while for others a broad range of potential uses exist.

Region 2, The Powder and Belle Fourche River Basins, is not treated in detail in the text as the region has no natural surface manifestations of thermal activity. The Madison Formation underlays the entirety of Region 2. In some areas it exhibits a significant potential for geothermal development. The formation is treated in detail in Appendix $A$.

Region 3, The North Platte River Basin, has two areas within it which have been treated in detail in this report.

The potentials of developing a district heating system for the municipal bulldings of Saratoga is discussed. This district could become a reality with the planning of the geothermally heated community recreation center currently underway.

The second area that is given detai led treatment is Midwest/Salt 
Creek. This area has significant geothermal potential because of the large volumes of moderate temperature waters being used in tertiary recovery. projects in the Salt Creek oil field. These large volumes are issuing from the Madison Formation which outcrops in part of Region 3.

A short discussion is given to the treatment of crude oil with geothermal heat by Continental oil near Glenrock. The process used is one that could be applied in oil fields where natural gas is not available to be burned as a heat source for field processing of the crude oil.

Region 4, The Green and Snake River Basins, contains the largest number and warmest of Wyoming's thermal springs. Nearly all of the thermal springs of this region are located in Teton County and many are either within Grand Teton National Park or one of the National Forests.

A detailed discussion of the Auburn Hot Spring Area is made in the first subchapter. Here a proposal is made for the development of an aquaculture application of the available geothermal fluids. The narrative addresses the trout farm aquaculture use but other fish may be equally or more suited to the potentials of Auburn.

The U.S. Fish and Wildlife Service operates a hatchery in Jackson Hole on the National Elk Refuge. The hatchery uses water from a warm spring to assist in the culturing of their fish. Minor modifications of the present system are presented and may prove to be very beneficial to the production of the hatchery.

Region 5, The Yellowstone River Basin, includes a discussion of Yellowstone National Park, whose geothermal resources have great potential, yet through its original mandate and the evolved administrative and legislative attitudes, no projected development or change from its current use as a public natural reserve can be anticipated.

Chapter VII deals with institutional issues which may effect geothermal development both on a state and a federal level. The chapter is a basic overview of the various agencies and their responsibilities. Leasing has become the responsibility of the State Land Office which issues exploration permits and geothermal leases. Yet, the responsibility for protecting thermal springs has belonged to the State Engineer for years. Therefore, clarification of the various roles currently mandated by statute is essential. In the future a legal/legislative framework should be developed to adequately address the needs of geothermal development. 


\section{CHAPTER IX \\ RECOMMENDATIONS}

1. Detailed study of state and federal regulations leading to legislation that streamlines the development process of geothermal energy.

2. State legislation which clearly identifies geothermal as groundwater, mineral, or a unique and distinct resource.

3. State legislation is needed to clarlfy the pecularities assoclated with geothermal exploration.

4. Consideration should be given at all governmental levels to. encourage the development of geothermal energy through incentive programs.

5. Continued resource evaluation in all substate regions.

6. Continued research into the extent and potential of the Madison Formation.

7. Development of an outreach program which will dellyer geothermal technology in a usable form to the general public. 


\section{THE MADISON FORMATION}

The Madison limestone formation underlies parts of Wyoming, North Dakota, South Dakota, and Montana. The formation was deposited under the area of the present day Powder River Basin in Wyoming approximately $300,000,000$ years ago during Mississippian time. This discussion of the Madison will be divided into two sections: The geohistory of the area, the depositional environment, and the current geology of the Powder River Basin, as well as reservoir engineering in the formation.

Structurally, the basin is a broad, down-warped asymmetric syncline overlying the relatively stable forelarid of the Cordilleran system. The strucfural relief from a high point in northeastern Campbell County to the deepest part in western Converse County is about 90,000 feet. This value is based on the thickening of the nonmarine late Cretaceous and early Tertiary sedimentary relief, and it is imperceptible in the Tertiary strata that dip to the southwest at about 100 feet per mile. Laramide deformation, Tertiary erosion, and continental sedimentation may have produced as much as 12,000 feet of total structural relief in the basin. (Figute $A-1$ ).

The general structural development of the Powder River Bas in may be summarized: as follows. During gental down-warping in Paleozoic time, sandstone, shale, and limestone were deposited in shallow seas and broad Carboniferous seasways. Mesozoic deposition is characterized by thin, transgressive marine deposits interbedded shaly marine and coarse nonmârine depositional beds. Uplift of the mountain ranges and subsidence of the enclosed area during the Laramide Orogeny blocked out this regional structural basin. Thick accumulations of Paleocene and Eocene rock accompanied the subsidence of the Basin. During Paleocene time, the Northern Great Plains was a vast swampy region from which extensive coal bed's developed. Rock types in the coal-bearing Fort Union Formation that was derived from the Laramie Range indicate erosion at about the same. rate as upliff of the range. The Tullock Member of the Fort Union marks the first evidence of down-warping in the basin whereas deposition of the thick sequence of mudstone of the Lebo Shale Member, which defines the margins of the basin, clearly indicates typical Laramide structure. The Laramide Orogeny was near its peak activity at the formation of the Tongue River Member as indicated by marked thickening of the sandstone and coalbeds. With the renewed uplift, the moisture-bearing winds were blocked off and the swampy gave way to grasslands. Unstable heavy mineral suites and the sub-angular shape of grains indicate that at least the Wasatch in the southern part of the basin had a nearby source, probably in the northern part of the Laramie Range. The down-warping of the Powder River Basin was completed in early Tertiary time. Subsidence of the enclosing mountain ranges after deposition of the oligocene White caused local tilting of these beds toward the mountains. Extensive erosion took place in late Tertiary time and most of the White River Formation and probably much of the Wasatch Formation were removed. Late Tertiary and Quanternary gravels were deposited on terraces, flood plains, and valley floors, and Holocene alluvium filled eroded channels in the older rocks. (Development of Coal Resources, 1974) 


\section{FIGURE $A-1$}

Generalized Geologic Section of Powder River Basin and Adjacent Areas

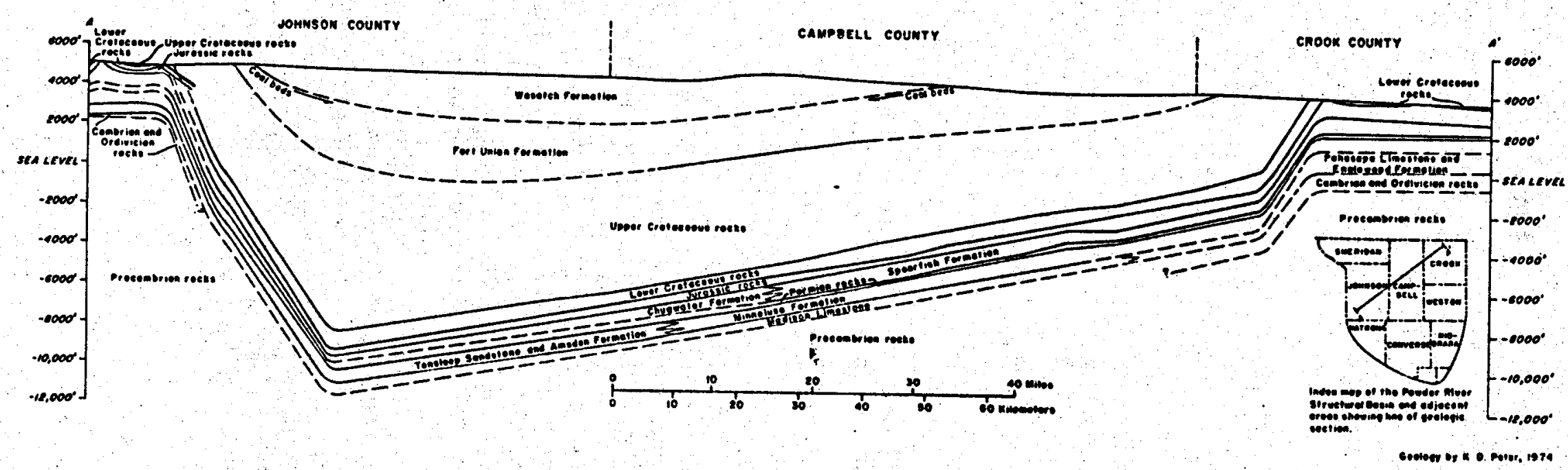

(Taken from Development of Coal Resources, 1974 p. I-196) 
The Madison Limestone and the eastward equivalent, Pahasapa Limestone, consist of dolomite and limestone. Both formations are cavernous, the upper part of the Madison is more cavernous than the lower part. The thickness ranges from 1,000 feet in the north to 100 feet in the south (Figure A-2). Yields of more than $1,000 \mathrm{gpm}$ of water are available from the Madison and Pahasapa Limestones where cavernous and fracture zones are present. Wells in Natrona County at depths of about 5,000 feet had . initial flows of 3,900 to $7,000 \mathrm{gpm}$ with from 150 to 179 psi flowing pressure at the surface from the Madison. Several wells in the Newcastle area of Weston County have flows of more than $1,000 \mathrm{gpm}$ from the Pahasapa at depths of about 3,000 feet.

The Madison Formation is large and deep and much of the temperatures which have been recorded at depth is due to normal temperature gradient. But there is uncertainty as to whether there is additional heat being supplied by a source other than normal gradient.

A preliminary study of temperature and depth to the Madison and the Minnelusa Formations indicates temperatures up to $140^{\circ} \mathrm{C}$. at a depth of is 11,500 feet just west of Gillette (Head, 1978). The Minnelusa and its western equivalent the Tensleep Formation, lie above the Madison (Figure $A-3)$. The temperatures indicate a somewhat greater than normal gradient (Figure A-4). The Madison itself follows the same contours of the bas in and is found at depths of over 16;000 feet below the surface, near Kaycee (Figure A-5): A broad area, below much of Campbell, Johnson, and Converse counties is shown to have a temperature of $140^{\circ}$ C. at depths of 11,500 to 15,000 feet below the surface (Figure $A-6$ ).

Discharge areas, other than from water wells, are not known, but considerable discharge from the Madison is belleved to be into overlying rocks where permeable rocks receptive to upward leakage overlie the Madison in Wyoming and in the adjoining states. In areas where chemical analysis are available from the Madison and from the overlying Minnelusa Formation, or Tensleep Sandstone, water from the Madison at nearly all locations contains less dissolved solids than the overlying rocks.

Many of the waters thus far discovered in the Formation have temperatures exceeding those due to the normal gradient, it seems economically feasible to recover this geothermal energy. The practical economics. of developing geothermat energy for community heating as well as other applications require more definite reservoir engineering data.

Presently the U.S. Geological Survey's Central Region Office in Denver is studying the effects over a limited area of large withdrawls of water from the Madison Aquifer. The water would be used for a proposed coal slurry pipeline in Wyoming. Although it encompasses parts of the Madison around the Black Hills area in South Dakota, this study is primarily intended to predict the effects of water withdrawl in Wyoming. The Cheyenne Office of the U.S. Geological Survey has a study: near completion on the Madison as part of this overall study. 
FIGURE A-2

Thickness of the Madison Limestone and equivalent rocks in the Powder River Basin and adjacent areas.

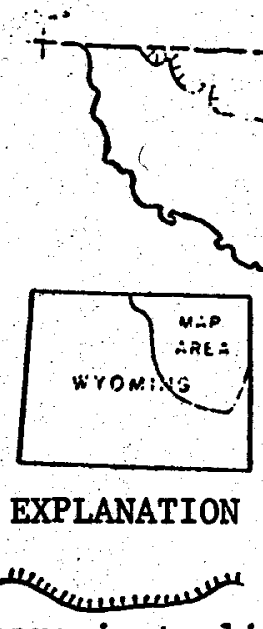

Approximate limit of Madison Limestone and equivalent rocks Major fault in or near outcrop of Madison Limestone and equivalent rocks

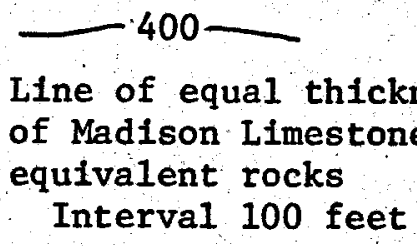

${ }^{100}$
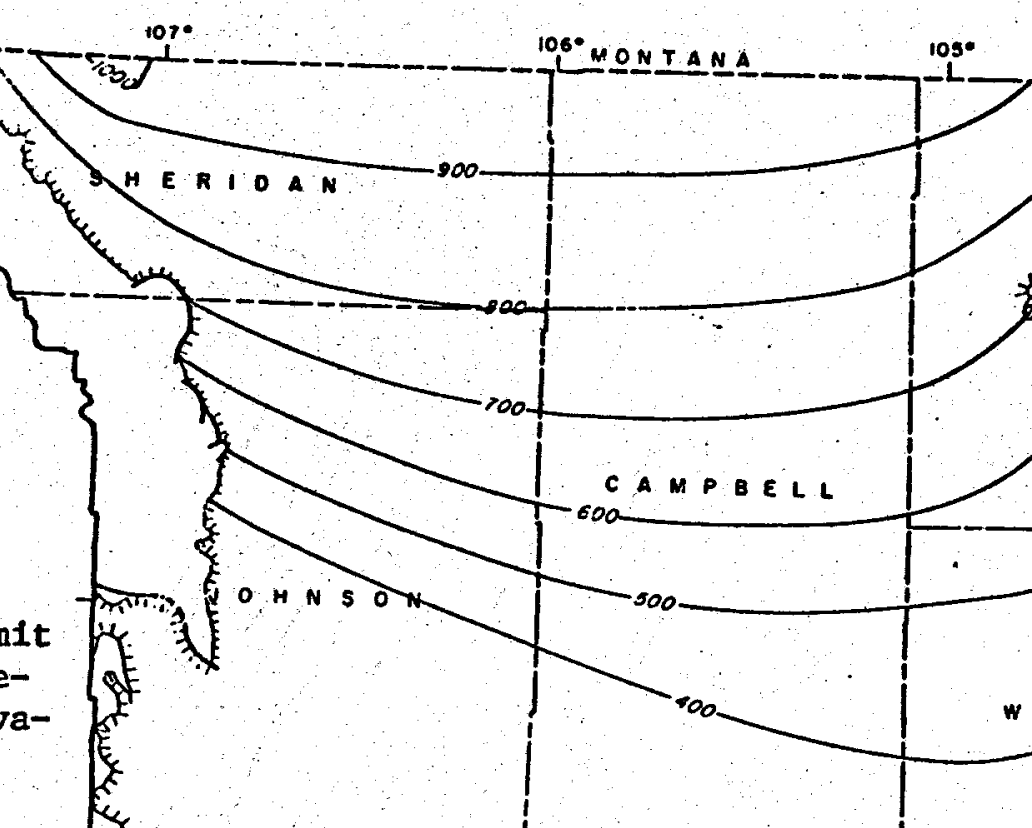
$\longrightarrow$
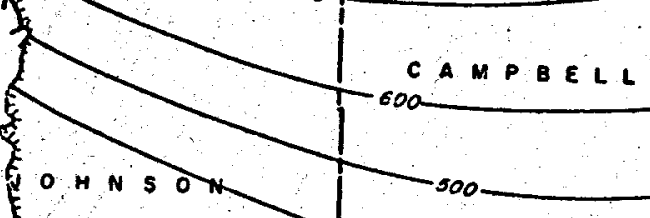

.
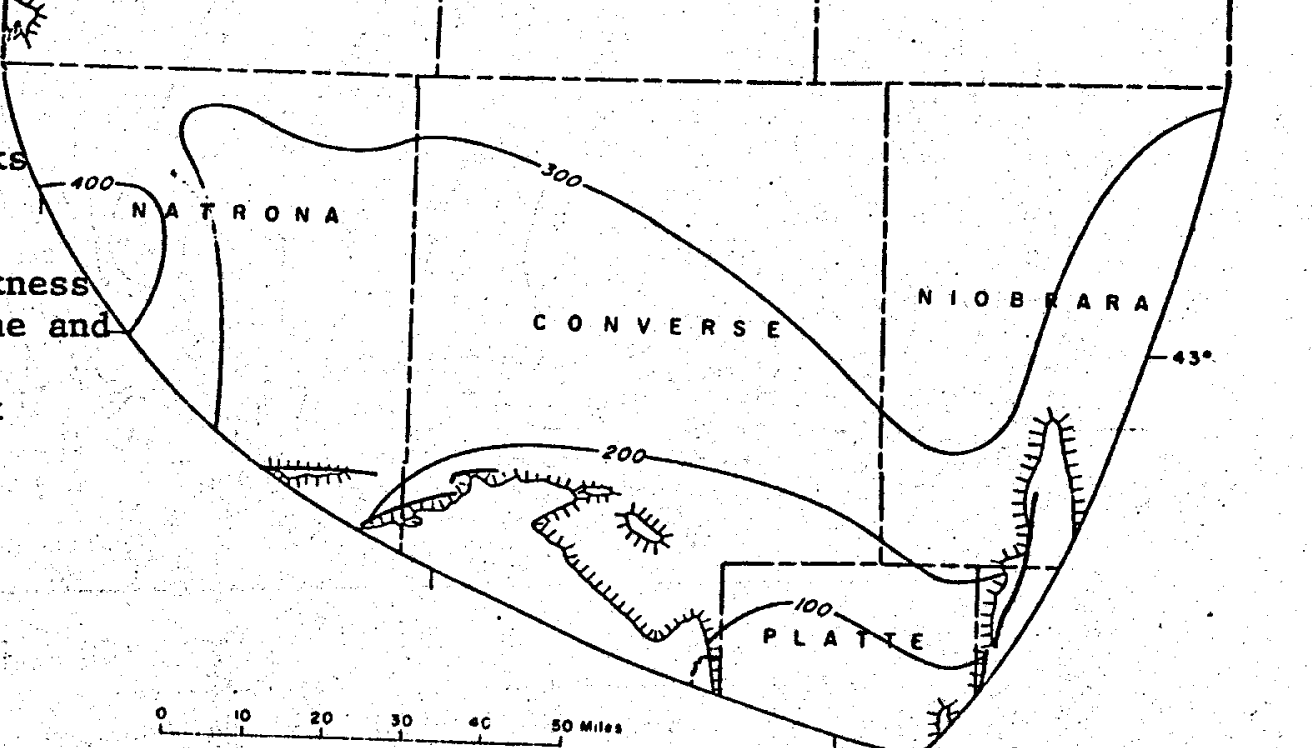


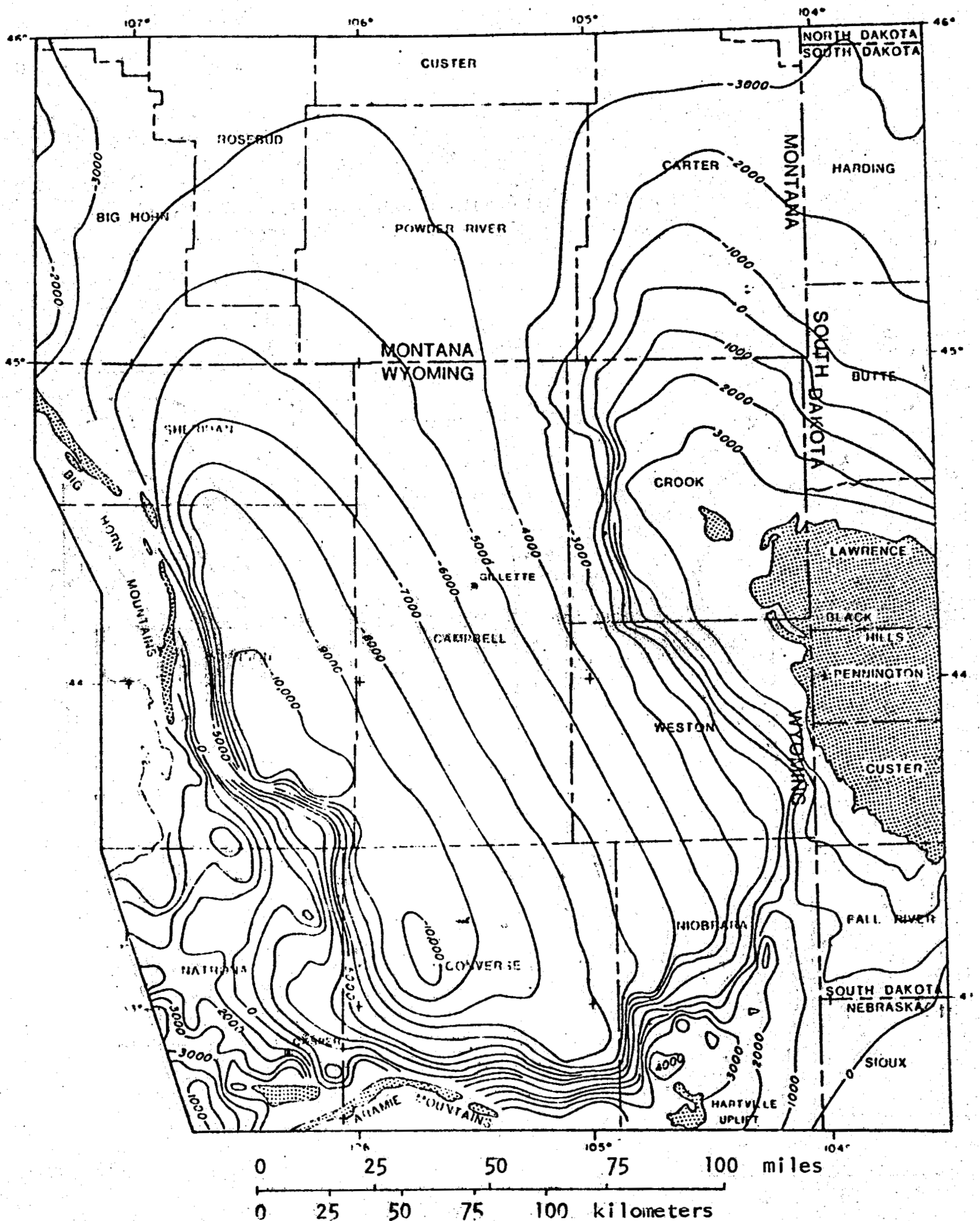

Figure

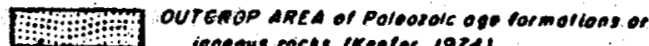
A-3

Configuration of the top of the Minnelusa Formation and equivalent rocks, taken from U.S.G.S. Open File Report $78-90.5$ by Head, Kilty and Knot tek. 


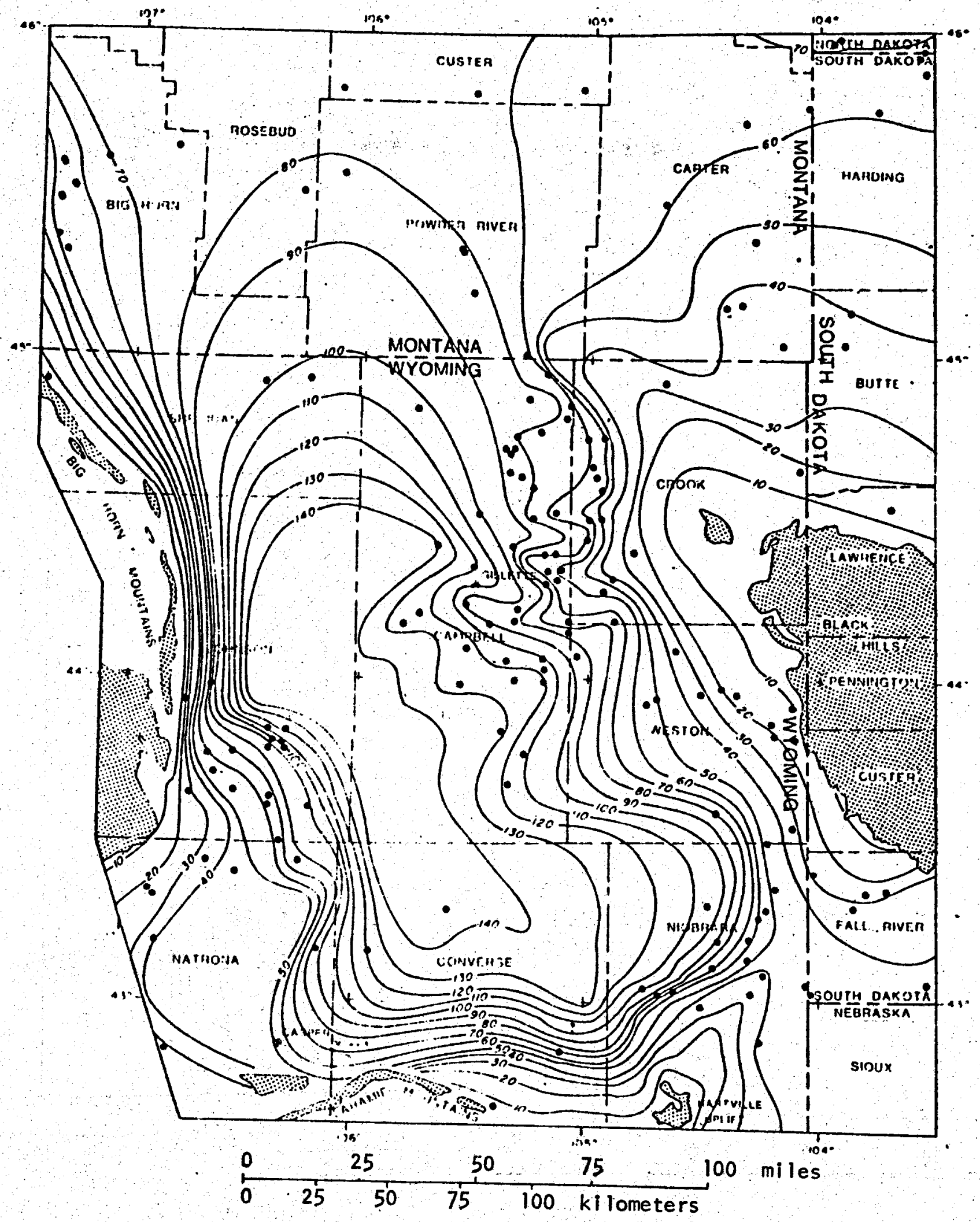

Figure

ExPLANATION

A-4

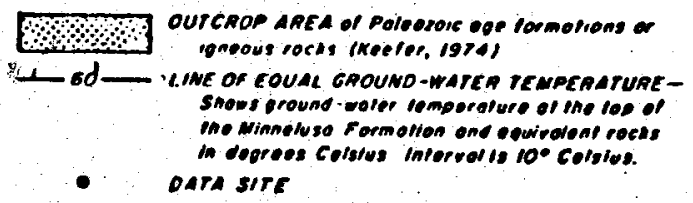

Ground Water Temperature in the Minnelusa Formation and equivalent rocks, taken from U.S.G.S. Open File Report $78-905$ by Head, Kilty and Knottek. 


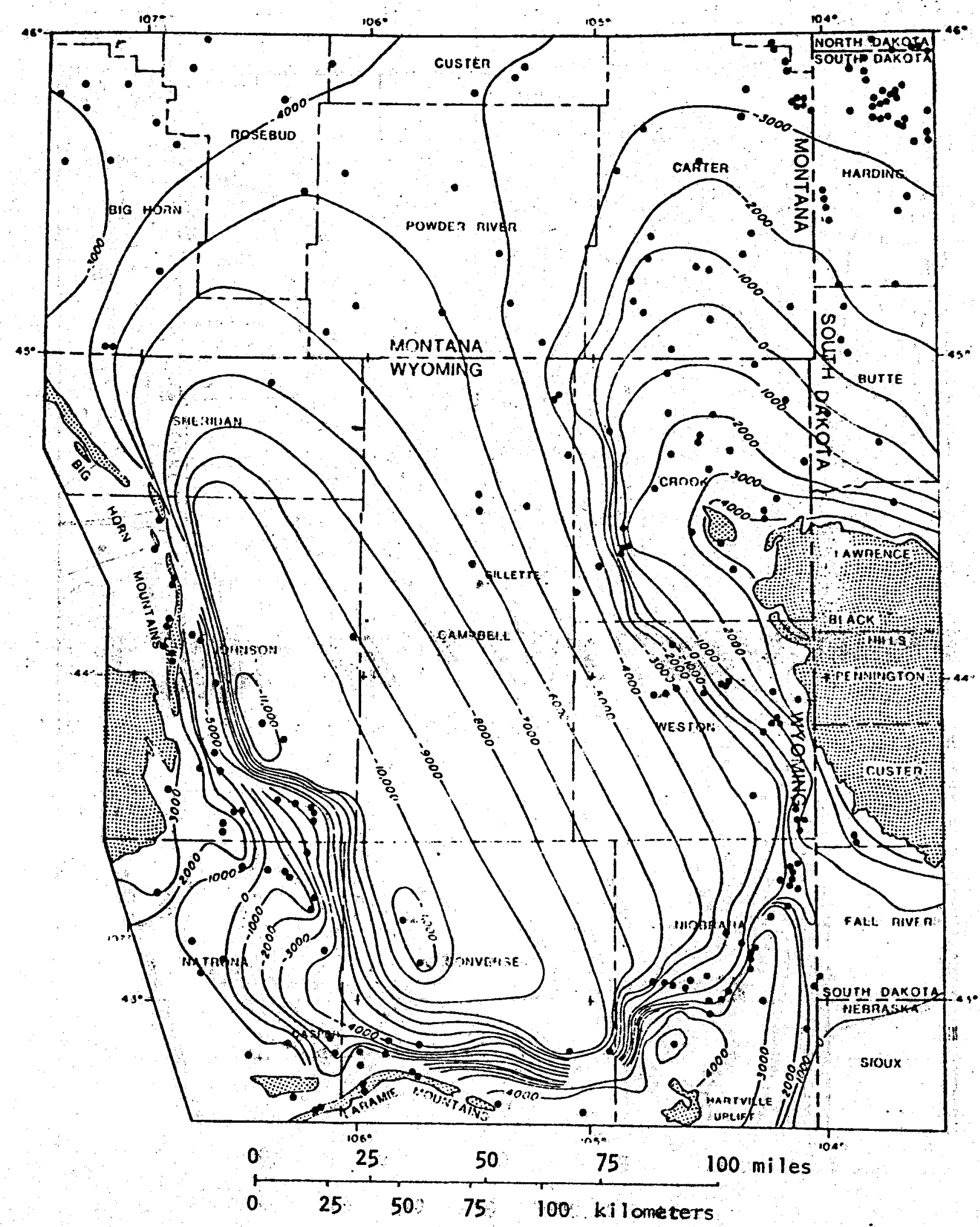

Explanation

Figure A-5

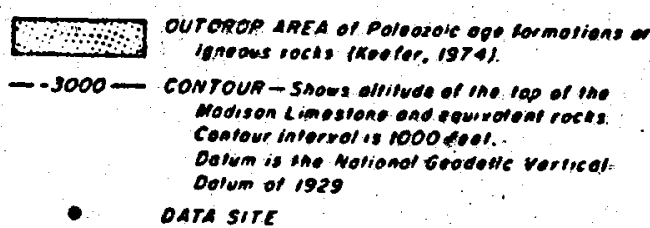

Configuration of the top of the Madison Limestone and equivalent rocks, taken from U.S.G.S. Open File Report 78-905 by Head, Kilty, and Knottek. 


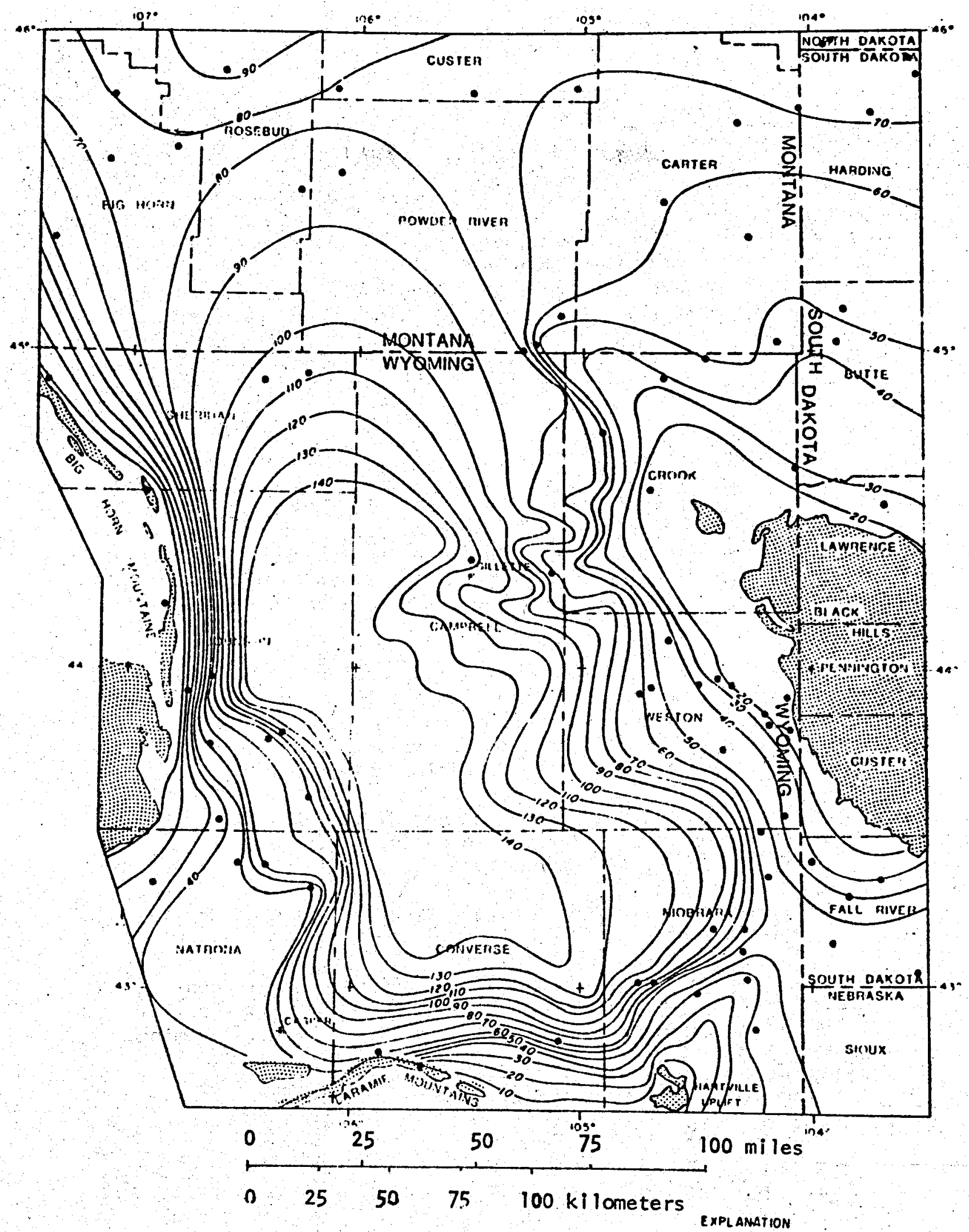

Figure A-6

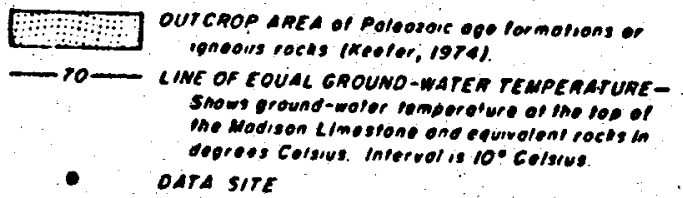

Ground Water Temperature in the Madison Limestone and equivalent rocks, taken from U.S.G.S. Open File Report 78-905 by Head, Kilty, and Knottek. 


\section{APPENDIX B}

RELATIVE HOME HEATING POTENTIALS OF WYOMING'S THERMAL RESOURCES

The determination of the value of a particular geothermal resource is dependent on how the resource is to be used. Sometimes a resource might be very well suited to space heating while being equally suited for agriculture. Another resource may have a limited potential use and could only be applied to space heating while being equally suited for agriculture. Another resource may have a limited potential use and could only be applied to space heating with heat pumps. The potential use of a resource is often times determined by site specific conditions. Furthermore, the needs of a given community may direct which application is eventually chosen.

Geothermal resources are not easily comparable as the potentail utilization of resources may differ greatly from one to another. Although two given resources may differ in their characteristics and in their proposed utilization this does not infer any judgement is being made as to whether they are more or less valuable as energy resources. Geothermal energy resources must be considered on a site by site basis and a final determination of utilization should be based on a broad range of site specific information.

Nevertheless it becomes apparent that some form of overall generalized comparison is important to ascertain the potential of various resources. Table B-I is an attempt to convert several of the major resources into an easily understood relative form. The following important assumptions were made in preparing the table.

1) $\Delta T^{\prime}$ 's indicate the estimated amount of heat in degrees $F$. that could be extracted from the resource. There are estimates and could change based on site specific conditions.

2) The use is considered to be:direct without the assistance of heat pumps.

3) The average home in Wyoming, for this purpose, is considered to be of 1,000 square feet. It is estimated that $35,000 \mathrm{Btu} / \mathrm{hr}$. would be needed for such a home in Wyoming.

4) There have been no considerations made for losses in temperature through transportation, piping, etc. 


\begin{tabular}{|c|c|c|c|c|c|c|}
\hline Site & Ownership & Temp. ${ }^{\circ} \mathrm{F}$. & $\Delta T$ & Btu/hr. & Flow gpm & $\begin{array}{l}\text { Number of } \\
\text { Homes Heated* }\end{array}$ \\
\hline $\begin{array}{l}\text { Midwest } \\
\text { Glenrock } \\
\text { Saratoga } \\
\text { Al cova }\end{array}$ & $\begin{array}{l}\text { Private } \\
\text { Private } \\
\text { Town } \\
\text { Bureau of }\end{array}$ & $\begin{array}{l}200^{\circ} \\
185^{\circ} \\
118^{\circ}\end{array}$ & $\begin{array}{l}40 \\
40 \\
30\end{array}$ & $\begin{array}{r}291,660,000 \\
4,660,000 \\
1,800,000\end{array}$ & $\begin{array}{r}14,583 \\
233 \\
120\end{array}$ & $\begin{array}{r}8,333 \\
133 \\
51\end{array}$ \\
\hline Huckleberry & $\begin{array}{l}\text { Reclamation } \\
\text { U.S. Forest }\end{array}$ & $129^{\circ}$ & 30 & $1,500,000$ & 100 & 43 \\
\hline $\begin{array}{l}\text { Auburn } \\
\text { Countryman } \\
\text { Big Springs - }\end{array}$ & $\begin{array}{l}\text { Service } \\
\text { Private } \\
\text { Private }\end{array}$ & $\begin{array}{l}142^{\circ} \\
144^{\circ} \\
100^{\circ}\end{array}$ & $\begin{array}{l}40 \\
40 \\
10\end{array}$ & $\begin{array}{r}6,000,000 \\
740,000 \\
2,500,000\end{array}$ & $\begin{array}{r}300 \\
37 \\
500\end{array}$ & $\begin{array}{r}171 \\
21 \\
71\end{array}$ \\
\hline $\begin{array}{l}\text { Thermopolis } \\
\text { Maytag - }\end{array}$ & State owned & $132^{\circ}$ & 30 & $43,620,000$ & 2,908 & 1,246 \\
\hline $\begin{array}{l}\text { Thermopol is } \\
\text { Saca jawea - }\end{array}$ & Private & $129^{\circ}$ & 30 & $8,085,000$ & 539 & 231 \\
\hline $\begin{array}{l}\text { Thermopolis } \\
\text { McCarthy - }\end{array}$ & Private & $125^{\circ}$ & 30 & $18,300,000$ & 1,220 & 523 \\
\hline $\begin{array}{l}\text { Thermopolis } \\
\text { White Sulfur - }\end{array}$ & Private & $129^{\circ}$ & 30 & $8,745,000$ & 583 & 250 \\
\hline $\begin{array}{l}\text { Thermopolis } \\
\text { Fort Washakle }\end{array}$ & $\begin{array}{l}\text { State owned } \\
\text { Wind River }\end{array}$ & $127^{\circ}$ & 30 & $3,090,000$ & 206 & 88 \\
\hline $\begin{array}{l}\text { Hot Springs } \\
\text { Granite Hot Springs }\end{array}$ & $\begin{array}{l}\text { Indlan Reservation } \\
\text { U.S. Forest Service }\end{array}$ & $111^{\circ}$ & 10 & 750,000 & 150 & 21 \\
\hline North Buffalo Fork & Private Lease & $106^{\circ}$ & 10 & $1,500,000$ & 300 & 43 \\
\hline $\begin{array}{l}\text { Springs } \\
\text { Little Sheep Mountain }\end{array}$ & U.S. Forest Service & $113^{\circ}$ & 10 & $1,000,000$ & 200 & 29 \\
\hline Springs & $\begin{array}{l}\text { Bureau of Land } \\
\text { Management }\end{array}$ & $68^{\circ}$ & 5 & $4,503,600$ & 1,800 & 129 \\
\hline TOTAL. & & & & $389,453,600$ & & $11: 383$ \\
\hline
\end{tabular}

*These numbers are expressed as equivelant homes of $1000 \mathrm{ft}^{2}$ floor space requiring 35,000 $\mathrm{Btu} / \mathrm{hr}$. heat demand. Public, commercial or industrial space heating use could be determined from the estimated Btu/hr. of the resource. 


\section{APPENDIX C \\ GEOTHERMAL APPLICATIONS}

A broad range of direct uses for geothermal energy exist. Some applications have a large range of temperatures where they could be applied, while others must be matched quite specifically with the resource capabilities.

The following figures show various geothermal uses and the corresponding temperature for the given use. Figure $\mathrm{C}-1$ shows the full spectrum of applications in degrees Celsius. Figure $\mathrm{C}-2$ is for space heating applications only and is given in degrees Fahrenheit." These applications are particularly suited to Wyoming's resources. 
The approximate required temperature of geothermal fluids

${ }^{\circ} \mathrm{C}$

190

Evaporation of Highly Cone. Solutions.

Refrigeration by Ammonia Absorption

Digestion in Paper Pulp., Kraft

$170-$ Heavy Water via Hydrog. Sulphide Proc.

Drying of Diatomacoous Earth.

160

Drying of Fish Meal.

Temp. Range of

Conventional

Drying of Timbor.

Power Production

Alumino vio Bayers Proc.

140 Orying Form Products af High Rates. Canning of Food.

$130-$ Evoporofion in Sugar Rofining.

Exfraction of Salfs by Evoporation and Crystalisation.

$120-$ Fresh Water by Distillation.

Most Multiple Effect Evaporations, Concentr. of Saline Sol.

Refigeration by Medlum Temperafures.

110 - Drying and Curing of Light Aggreg. Coment Slabs.

100 - Drying of Organic Materials, Seaweeds, Grass, Vegetobles elc. Washing and Drying of Wool.

Drying of Stock Fish.

Intens De-Icing Operations.

$80-$ Space Heating.

Greenhouses by Space Heating.

70 Refrigeration by Low Temperature.

60 Animal Husbandry Greenhouses by Combined Space and Hotbed Heating.

Animal Husbondry.

50 Mushroom Growing.

Balneological Boths.

40 Soil Warming.

30 Swimming Pools, Biodegretation, Fermentations.

Warm water for year oround Mining in Cold Climafes.

$20 \int$ Hatching of Fish. Fish Farming.

Taken from Linda1, 1974, "Geothermal Energy for Process Use" in Multipurpose Use of Geothermal Energy, 1974. Oregon Institute of Technologv. 
FIGURE C-2

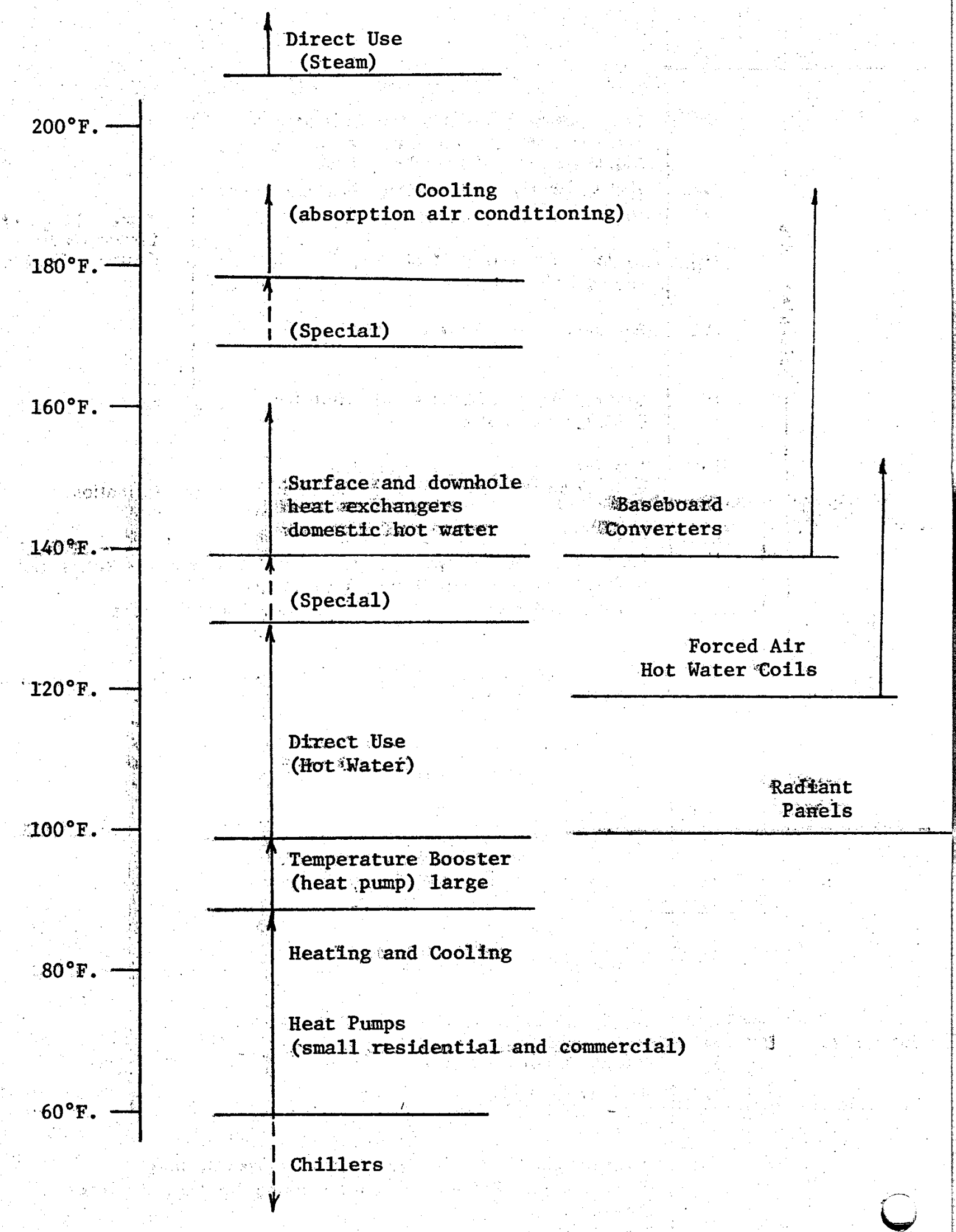

Adapted from Lienau, P.J., 1978, "Space Conditioning with Geotherma1 Energy", A Conference on the Commercialization of Geothermal Energy. 


\section{BIBLIOGRAPHY}

Bartlett, A.B., 1926. The Mineral Hot Springs of Wyoming: Wyoming Geologist's Office, Bull. 16.

Behrendt, J.C., Tibbetts, B.L., Bonini, W.E., and Lavin, P.M., 1968. A Geophysical study in Grand Teton. Natlonal Park and vicinity, Teton, Co., Wyoming, with sections on stratigraphy and structure by J.D. Love and Precambrian rocks by J.C. Reed: U.S. Geologlcal Survey Prof. Paper 516-E.

Becker C.F., and Alyea, J.D., 1964. Preclpitation Probabilities in Wyoming. Agricultural Experiment Station, University of Wyoming, Laramie, Wyoming.

Blackstone, D., Jr., 1971. Traveler's Guide to the Geology of Wyoming. The Geological Survey of Wyoming. Laramie, Wyoming. Second Edition, p. 46-51.

Blackwell, D.D., 1969. Heat-flow Determinations in the Northwestern United States: Jour. Geophys. Res., V. 74, no. 4. p. 992-1007.

Breckenridge, R.M., and Hinckley, B.S., 1978. Thermal Springs of Wyoming, Bulletin 60. The Geological Survey of Wyoming, Laramie, Wyoming.

Chemlcal Quality of Water in Southeastern Wyoming. 1971. USGS, Wyoming Department of Economic Planning and Development, Cheyenne, Wyoming.

Coury, G.E., and Vorum, M., 1978. "San Luis Valley, Colorado: A Region of High Potential for Geothermal Development," Geothermal Resources Councill.

Cox, E.R., 1975. Discharge Measurements and Chemical Analysis of Water in Northwestern Wyoming. USGS, Wyoming Water Planning Program, Cheyenne, Wyoming.

Criticle Water Problems Facing the Eleven Western States, 1975. U.S. Department of the Interior.

Culver, Lund, and Svanevik, 1974. Klamath Falls Hot Water Well study. Geo-Heat Utillization Center, Oregon Institute of Technology, Klamath Falls, Oregon.

Darton, N.H., 1906a. The Hot Springs at Thermopolls, Wyoming: Jour. of Geol., V. 14, no. 3, P. 194-200.

Decker, E.R., 1976. Geothermal Resources, Present and Future Demand for Power and Legislation in the State of Wyoming: Wyoming Geological Survey, Public Information Series 1, P. 21.

Development of Coal Resources in the Eastern Powder River Coal Bas in of Wyoming, Draft Environmental Statement, 1974. 
U.S. Department of the Interior, Cheyenne, Wyoming, Vol. I, Pp. 165229.

Donley, H.F., 1978. Groundwater/Hot Springs and Ledge Rock Investigation. Letter to town of Saratoga.

Economic Blueprint Component of Public Investment Plan, 1975. DEPAD, Wyoming Industrial Development Corporation.

Geothermal: State of the Art, 1977. Geothermal Resources Council, Davis, Callfornia.

Geothermal Energy: A Novelty Becomes Resource, 1978. Geothermal Resources Council, Davis, California: Vol. 11, Sec. $1,2$.

Geothermal Energy Resources of the Western U.S., 1977. National Geophysical and Solar-Terrestrial Data Center, Boulder, Colorado.

Glass, G.B., Wendell, W.G., Root, F.K., and Breckenridge, R.M., 1975. Energy Resources Map of Wyoming, Geological Survey of Wyoming.

Head, W.J., Kilty, K.T., and Knottek, R.K., 1978. Maps Showing Formation Temperatures and Configurations of the Tops of the Minnelusa Formation and the Madison Limestone, Powder River Basin, Wyoming, Montana, and Adjacent Areas. U.S. Geological Survey. (Open File Report, 78-905) Cheyenne, Wyoming.

Hodson, W.G., 1971. Chemical Analysis of the Groundwater in the Powder River Basin and Adjacent Areas, Northeastern Wyoming. USGS, Wyoming Department of Economic Planning and Development, Cheyenne, Wyoming.

Jacksan, R.L., 1977. Geothermal Heating, Utillizing Madison Formation Water, A Thesis. University of Wyoming, Laramie, Wyoming.

Keefer, W.R., 1976. The Geologic Story of: Yellowstone National Park. USGS and the Yellowstone Library and Museum Association.

Kunze, Whitbeck, Miller, and Griffity, 1977-1978. "Making Electricity from Moderate Temperature Fluids," Geothermal World Directory.

Land Status, State of Wyoming, 1978. U.S. Department of the Interior, Bureau of Land Management.

Land and Water Law Review, 1977. University of Wyoming College of Law, Geothermal Resources Development Institute, Vol. XIII, no. 1.

Leffel, C.S., Jr., and Eisenberg, R.A., 1977. Geothermal Handbook, John Hopkins University Applied "Physics Laboratory.

Lienau, P.J., (Principal Investigator), 1978. Agribusiness Geothermal Energy Utilization Potential of Klamath and Western Snake River Basins, Oregon. Geo-Heat Utilization Center, Oregon Institute of Technology, Klamath Falls; Oregon. 
Llenau, P.J., and Lund, J.W., (Editors,) 1974. Multipurpose Use of Geothermal Energy. Geo-Heat Utilization Center, Oregon Institute of Technology, Klamath Falls, Oregon.

Llenau, Culver, and Lund, 1977a. "Klamath Falls Geo-Heating Districts."

Lienau, P.J., Lund, J.W., and Culver, G.G., 1977b. Klamath County GeoHeating District Feaslbility Study. Geo-Heat Utillzation Center, Oregon Institute of Technology, Klamath Falls; Oregon.

Love, J.D., Weitz, T.H., and Hose, R.K., 1955. Geologlc Map of Wyoming. U.S. Geological Survey.

Lowry, M.E., 1967. Saratoga Hot Springs Analysis: Wyoming Geological Survey, Open File Report.

Lowry, M.E., and Lines, G.C., 1972. Chemlcal Analysis of Groundwater In the Bighorn Basin, Northwestern Wyoming. USGS, Wyoming Department of Economic Planning and Development, Cheyenne, Wyoming.

Master Plan - Yellowstone National Park, 1973. U.S. Department of the Interior, National Park Service, Denver. Service Center, Denver, Colorado.

Outdoor Recreation Plan for Wyoming, An, 1975. Wyoming Recreation Commission, Cheyenne, Wyoming.

Report on Prelliminary Data for Madison Limestone Test Well No. 1, 1977. U.S. Geological Survey, Open FIle Report 77-164, Denver, Colorado.

Reservoir Engineering of the Madison Limestone Formation, John Hopkins University Applied Physics Laboratory, Quarterly Report, Oct-Dec. 1977, pp. 13-22.

Rules and Regulations Governing the Issuance of Geothermal Resource Permits and Leases, 1975. State of Wyoming, State Board of Land Commissioners.

Saratoga Land Use Plan, The, 1977. The Town of Saratoga, Saratoga, Wyoming.

Smiley, W.E., 1975. Substate Districting for Wyoming - A Preliminary Study. Planning Division, Wyoming Department of Economic Planning and Development, Cheyenne, Wyoming.

State Department of Economic Planning and Development, Fiscal Year Report, 1975. State of Wyoming, Cheyenne, Wyoming.

State of Wyoming, 1967. Base Map, U.S. Department of the Interior, Geological Survey.

Statewide Land Use Planning Program for Wyoming, 1974. The Wyoming Conservation and Land Use Study Commission, Vol. 1, 11. 
Tratner, Alan Arthur, 1977-1978. Editor in Chief and Publisher, Geothermal World Directory, 1977-1978.

USGS, Kane Quadrangle; Wyoming - Big Horn County, 7.5 Minute Series, Topographic, 1964.

USGS Midwest Quadrangle, Wyoming, 7.5 Minute Series, Topographic, 1968.

USGS Saratoga Quadrangle, Wyoming - Carbon County, 7.5 Minute Series, Topographic, 1961 .

USGS, Spence Quadrangle, Wyoming - Big Horn County, 7.5 Minute Series, Topographic, 1966.

Wehlage, E.F., 1976. The Basics of Applied Geothermal Engineering, Geothermal information Services, West Covina, California.

Wyoming: A Land Use Inventory, 1973. Water Resources Research Institute, Laramie, Wyoming, and the League of Women Voters of Wyoming, pp. 2-5.

Wyoming Framework tater Plan, The, 1973. State Englneerls office, Wyoming Water Planning Program, Cheyenne, Wyoming, p.. $17 \div 8$.

Wyoming Mineral Industry, The, 1978. Geological Survey of Wyoming, Public Information Circular No. 8.

Wyoming Official Directory, 1978. Secretary of State, State of Wyoming.

Wyoming Official Highway Map, 1978. "Wyoming State Highway Commission, Cheyenne, Wyoming.

Wyoming: Planning System Summary, 1975. Bureau of Land Management, Cheyenne, Wyoming. 


\section{ADDITIONAL REFERENCES}

Boutain, Karin, Personal Communication, County Planner, Big Horn County, Basin, Nyoming.

Countryman, Betty, Personal Communlcation, South of Lander, Wyoming.

Dicky, Lynn, Personal Communication, Wyoming Energy Conservation Office, Cheyenne Wyoming.

Foley, Duncan, Personal Communication, Geologist, UURI, Salt Lake Clty, Utah.

Galovitch, Joe, Personal Communication, 7/78, Continental 0ll Company, Casper, Wyoming.

Hoffman, D.S., Personal Communication, 9/78, Department of Economic Planning and Development, Cheyenne, Wyoming.

Hutchenson, Rick, Personal Communication, 9/78, Naturalist, Yellowstone Natural Park.

Johnson, Bill, Personal Communication, 8/78, Oregon Institute of Technology, Klamath Falls, Oregon.

McClain, D., Personal Communication, 9/78, Idaho Office of Energy, Boise, Idaho.

McGuire, Richard, Personal Communication, 9/78, Mariah Assoclates, Laramie, Wyoming.

Miller, Dan, Personal Communication, State Geologist, Wyoming Geological Survey, Laramie, Wyoming.

Norman, Marilyn, Personal Communication, Administrative Assistant, Town of Saratoga, Wyoming.

Sipe, Fred J., Personal Communication, 9/78, Saratoga Recreation Board, Saratoga, Wyoming.

Tarshis, Andrew, Personal Communication, Geologist, Bureau of Land Management, Cheyenne, Wyoming.

Wilkes, Lorna, Personal Communication, Wyoming Energy Conservation Office, Cheyenne, Wyoming. 